Prepared in cooperation with the Central Platte Natural Resources District and Nebraska Public Power District

\title{
Capacitively Coupled and Direct-Current Resistivity Surveys of Selected Reaches of Cozad, Thirty-Mile, Orchard-Alfalfa, Kearney, and Outlet Canals in Nebraska, 2012-13
}

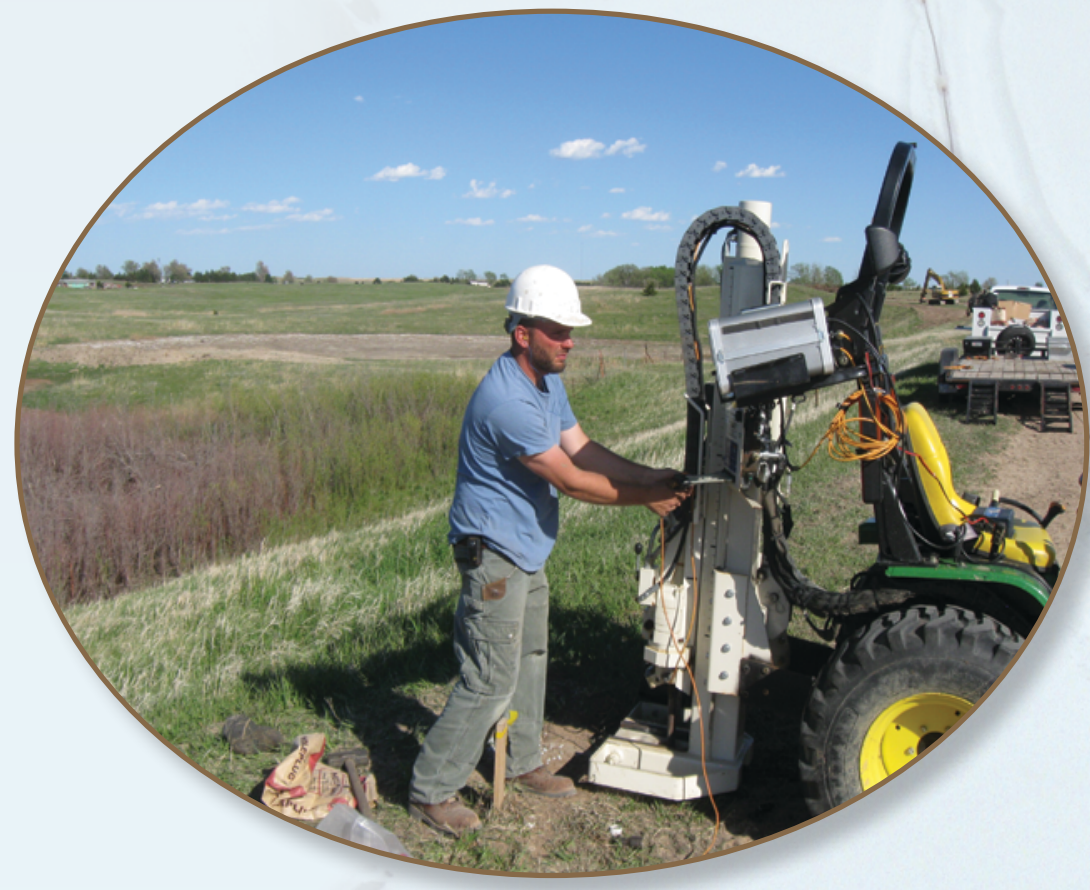

Open-File Report 2014-1007

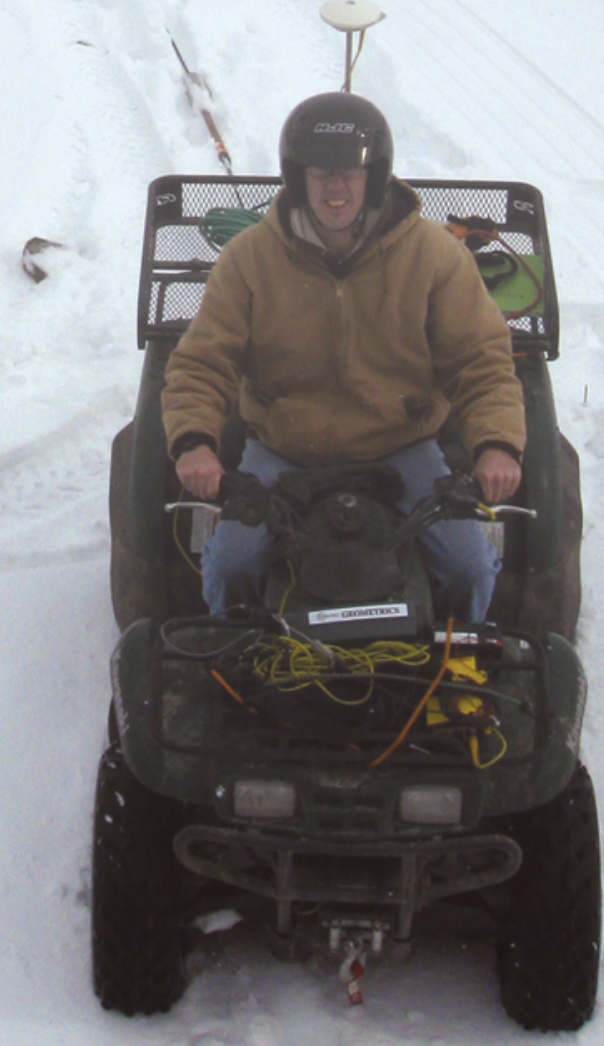

U.S. Department of the Interior

U.S. Geological Survey 
Cover. Background: Collecting capacitively coupled resistivity data along Kearney Canal. Photograph by Chris Hobza. Inset: Direct push electrical conductivity logging near Outlet Canal. Photograph by Ryan Tompkins. 


\section{Capacitively Coupled and Direct-Current Resistivity Surveys of Selected Reaches of Cozad, Thirty-Mile, Orchard-Alfalfa, Kearney, and Outlet Canals in Nebraska, 2012-13}

By Christopher M. Hobza, Bethany L. Burton, Jeffrey E. Lucius, and Ryan E. Tompkins

Prepared in cooperation with the Central Platte Natural Resources District and Nebraska Public Power District

Open-File Report 2014-1007 


\title{
U.S. Department of the Interior SALLY JEWELL, Secretary
}

\section{U.S. Geological Survey Suzette M. Kimball, Acting Director}

\author{
U.S. Geological Survey, Reston, Virginia: 2014
}

For more information on the USGS - the Federal source for science about the Earth, its natural and living resources, natural hazards, and the environment, visit http://www.usgs.gov or call 1-888-ASK-USGS.

For an overview of USGS information products, including maps, imagery, and publications, visit http://www.usgs.gov/pubprod

To order this and other USGS information products, visit http://store.usgs.gov

Any use of trade, firm, or product names is for descriptive purposes only and does not imply endorsement by the U.S. Government.

Although this information product, for the most part, is in the public domain, it also may contain copyrighted materials as noted in the text. Permission to reproduce copyrighted items must be secured from the copyright owner.

Suggested citation:

Hobza, C.M., Burton, B.L., Lucius, J.E., and Tompkins, R.E., 2014, Capacitively coupled and direct-current resistivity surveys of selected reaches of Cozad, Thirty-Mile, Orchard-Alfalfa, Kearney, and Outlet Canals in Nebraska, 2012-13: U.S. Geological Survey Open-File Report 2014-1007, 48 p., http://dx.doi.org/10.3133/ofr20141007.

ISSN 2331-1258 (online) 


\section{Acknowledgments}

The authors would like to thank Duane Woodward, from the Central Platte Natural Resources District, for his assistance during data collection. Thanks also are extended to Ed Dekleva Jr. and Jeff Shafer, from the Nebraska Public Power District, for logistical help during data collection and for the thoughtful suggestions made to this report. 


\section{Contents}

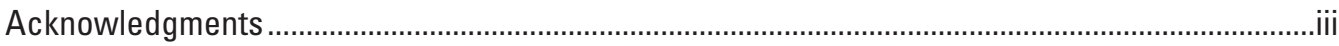

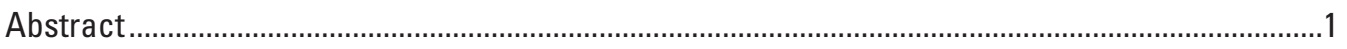

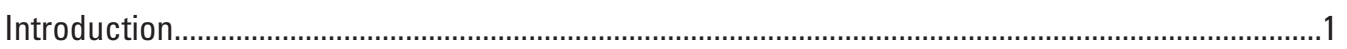

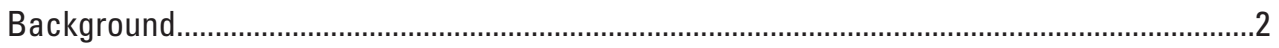

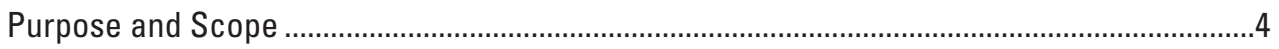

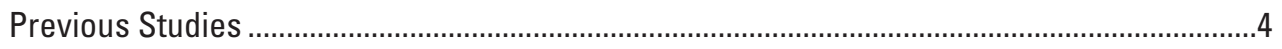

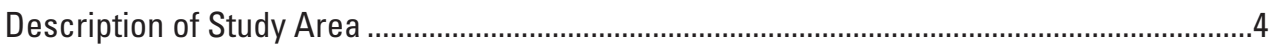

Description of Irrigation Canals .....................................................................................

Geology and Hydrogeology ........................................................................................

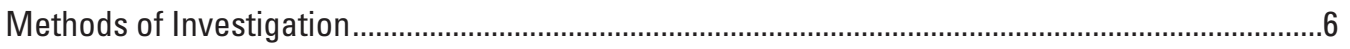

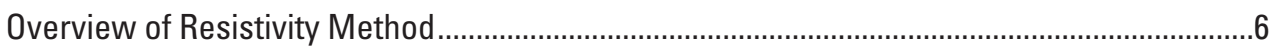

Capacitively Coupled Resistivity Methods ……………...........................................................

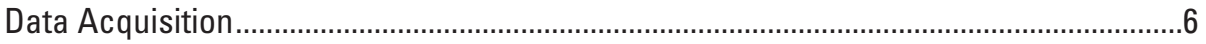

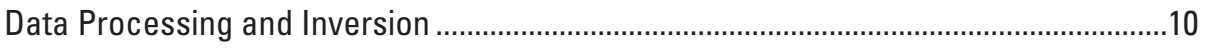

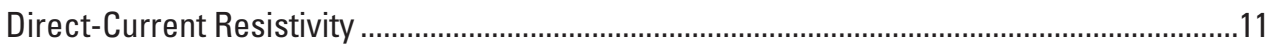

Continuous Sediment Cores and Direct-Push Electrical Conductivity Logging ......................11

Capacitively Coupled and Direct-Current Resistivity ..................................................................12

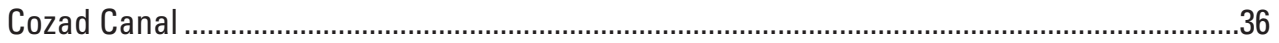

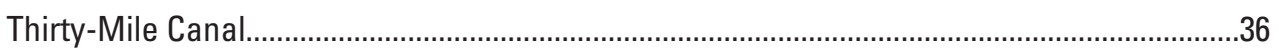

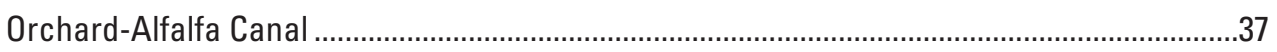

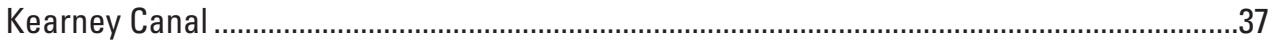

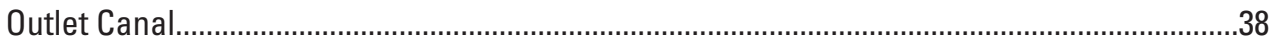

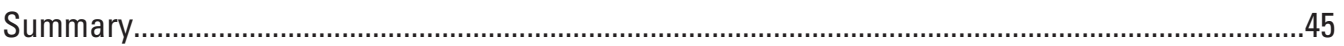

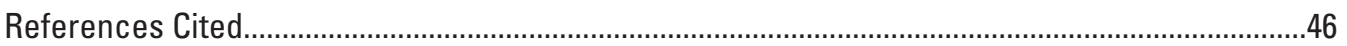

\section{Figures}

1. Map showing location of study area and canals, where capacitively coupled and direct-current resistivity profiles were collected

2. Map showing location of continuous sediment cores and canal reaches surveyed with capacitively coupled resistivity methods in Dawson and Buffalo Counties, Nebraska

3. Map showing location of capacitively coupled and direct-current resistivity surveys and continuous sediment cores and five direct-current resistivity lines collected on the north side of Outlet Canal near a seep near Outlet Canal mile post 15.55

4. Schematic illustration showing the capacitively coupled resistivity-system setup and geometry.

5. Diagrams and map showing comparison of capacitively coupled resistivity section and lithologic and electrical conductivity data from core $\mathrm{C} 1$

6. Diagrams and map showing comparison of capacitively coupled resistivity section and lithologic and electrical conductivity data from core $\mathrm{C} 2$ 
7. Diagrams and map showing comparison of capacitively coupled resistivity section and lithologic and electrical conductivity data from core C3

8. Diagrams and map showing comparison of capacitively coupled resistivity section and lithologic and electrical conductivity data from core TM1

9. Diagrams and map showing comparison of capacitively coupled resistivity section and lithologic and electrical conductivity data from core TM2.

10. Diagrams and map showing comparison of capacitively coupled resistivity section and lithologic and electrical conductivity data from core TM3

11. Diagrams and map showing comparison of capacitively coupled resistivity section and lithologic and electrical conductivity data from core OA1

12. Diagrams and map showing comparison of capacitively coupled resistivity section and lithologic and electrical conductivity data from core $0 \mathrm{~A} 2$

13. Diagrams and map showing comparison of capacitively coupled resistivity section and lithologic and electrical conductivity data from core K2 (Buckle)

14. Diagrams and map showing comparison of capacitively coupled resistivity section and lithologic and electrical conductivity data from core $\mathrm{K} 1$.

15. Diagrams and map showing comparison of capacitively coupled resistivity section and lithologic and electrical conductivity data from cores G4 and G1

16. Diagrams and map showing comparison of capacitively coupled resistivity section and lithologic and electrical conductivity data from cores $\mathrm{G} 3$ and G2

17. Maps showing vertically averaged resistivity and location of sediment cores for Cozad, Thirty-Mile, Orchard-Alfalfa, and Kearney Canals.

18. Section showing results from an inverted capacitively coupled resistivity model and an inverted direct-current resistivity model along Outlet Canal access road north line

19. Section showing results from an inverted capacitively coupled resistivity model and an inverted direct-current resistivity model along Outlet Canal access road south line

20. Schematic cross-sectional diagram of north bank of Outlet Canal near mile post 15.55 showing remnant of original compacted-core bank and its modifications with respect to location of direct-current resistivity lines along canal roadside south and north lines

21. Inverse modeling results showing direct-current resistivity profiles at the seep near Outlet Canal mile post 15.55 along the canal access road and near piezometers PZ-4 and PZ-5.

22. Inverse modeling results showing capacitively coupled resistivity profile for Outlet Canal access road south line near the seep near mile post 15.55 .

23. Inverse modeling results showing capacitively coupled resistivity profile for Outlet Canal access road north line near the seep near mile post 15.55.

\section{Tables}

1. Irrigated area, maximum flow rate, average annual diversion, and estimated seepage of selected canals in central Nebraska ...

2. Detailed lithologic descriptions from continuous sediment cores 


\section{Conversion Factors}

\begin{tabular}{|c|c|c|}
\hline Multiply & By & To obtain \\
\hline \multicolumn{3}{|c|}{ Length } \\
\hline centimeter $(\mathrm{cm})$ & 0.3937 & inch (in.) \\
\hline millimeter (mm) & 0.03937 & inch (in.) \\
\hline meter $(\mathrm{m})$ & 3.281 & foot $(\mathrm{ft})$ \\
\hline kilometer (km) & 0.6214 & mile (mi) \\
\hline \multicolumn{3}{|c|}{ Area } \\
\hline hectare (ha) & 2.471 & acre \\
\hline hectare (ha) & 0.003861 & square mile $\left(\mathrm{mi}^{2}\right)$ \\
\hline square kilometer $\left(\mathrm{km}^{2}\right)$ & 0.3861 & square mile $\left(\mathrm{mi}^{2}\right)$ \\
\hline \multicolumn{3}{|c|}{ Volume } \\
\hline cubic meter $\left(\mathrm{m}^{3}\right)$ & 0.0008107 & acre-foot (acre-ft) \\
\hline cubic hectometer $\left(\mathrm{hm}^{3}\right)$ & 810.7 & acre-foot (acre-ft) \\
\hline \multicolumn{3}{|c|}{ Flow rate } \\
\hline cubic meter per second $\left(\mathrm{m}^{3} / \mathrm{s}\right)$ & 35.31 & cubic foot per second $\left(\mathrm{ft}^{3} / \mathrm{s}\right)$ \\
\hline liter per minute (L/min) & 0.2642 & gallon per minute ( $\mathrm{gal} / \mathrm{min})$ \\
\hline centimeter per year $(\mathrm{cm} / \mathrm{yr})$ & 0.3937 & inches per year (in/yr) \\
\hline \multicolumn{3}{|c|}{ Velocity } \\
\hline kilometer per hour $(\mathrm{km} / \mathrm{hr})$ & 0.6214 & mile per hour \\
\hline \multicolumn{3}{|c|}{ Hydraulic conductivity } \\
\hline meter per second $(\mathrm{m} / \mathrm{s})$ & 3.281 & foot per second $(\mathrm{ft} / \mathrm{s})$ \\
\hline \multicolumn{3}{|c|}{ Frequency } \\
\hline hertz (Hz) & 1 & cycle per second \\
\hline kilohertz (kHz) & 1,000 & cycles per second \\
\hline
\end{tabular}

Temperature in degrees Celsius $\left({ }^{\circ} \mathrm{C}\right)$ may be converted to degrees Fahrenheit $\left({ }^{\circ} \mathrm{F}\right)$ as follows:

${ }^{\circ} \mathrm{F}=\left(1.8 \mathrm{x}^{\circ} \mathrm{C}\right)+32$.

Vertical coordinate information is referenced to the North American Vertical Datum of 1988 (NAVD 88).

Nebraska Public Power District Datum is $0.264 \mathrm{~m}$ ( 0.866 feet) above the North American Vertical Datum of 1988.

Horizontal coordinate information is referenced to the North American Datum of 1983 (NAD 83).

Altitude, as used in this report, refers to distance above the vertical datum. 


\title{
Capacitively Coupled and Direct-Current Resistivity Surveys of Selected Reaches of Cozad, Thirty-Mile, Orchard-Alfalfa, Kearney, and Outlet Canals in Nebraska, 2012-13
}

\author{
By Christopher M. Hobza, Bethany L. Burton, Jeffrey E. Lucius, and Ryan E. Tompkins
}

\begin{abstract}
Understanding the spatial characteristics of leakage from canals is critical to effectively managing and utilizing water resources for irrigation and hydroelectric purposes. Canal leakage in some parts of Nebraska is the primary source of water for groundwater recharge and helps maintain the base flow of streams. Because surface-water supplies depend on the streamflow of the Platte River and the available water stored in upstream reservoirs, water managers seek to minimize conveyance losses, which can include canal leakage. The U.S. Geological Survey, in cooperation with the Central Platte Natural Resources District and Nebraska Public Power District, used capacitively coupled (CC) and direct-current (DC) resistivity techniques for continuous resistivity profiling to map near-surface lithologies near and underlying the Cozad, Thirty-Mile, Orchard-Alfalfa, Kearney, and Outlet Canals.

Approximately 84 kilometers $(\mathrm{km})$ of CC-resistivity data were collected along the five canals.

The CC-resistivity data were compared with results from continuous sediment cores and electrical conductivity logs. Generally, the highest resistivities were recorded at the upstream reaches of the Cozad, Thirty-Mile, and OrchardAlfalfa canals where flood-plain deposits of silt and clay mantle coarser channel deposits of sand and gravel. The finer grained deposits gradually thicken with increasing distance away from the Platte River. Consequently, for many surveyed reaches the thickness of fine-grained deposits exceeded the 8-meter depth of investigation.

A detailed geophysical investigation along a 5-km reach of the Outlet Canal southwest of North Platte, Nebraska, used CC and DC resistivity to examine the condition of a compacted-core bank structure and characterized other potential controls on areas of focused seepage. CC-resistivity data, collected along the 5-km study reach, were compared with continuous sediment cores and DC-resistivity data collected near a selected seep near Outlet Canal mile post 15.55 along 5 separate profiles. DC-resistivity results were compared to
\end{abstract}

a schematic cross section of the Outlet Canal north embankment that include the original surfaces and modifications to the compacted-core bank structure.

Along the canal road south line, there is a transition from high resistivity at land surface to much lower resistivity near the estimated depth of the northern slope of the original compacted-core bank; however, the surveyed elevation of the water surface in the canal also is at this elevation. Along the canal road north line, there is a transition from high resistivity near land surface to lower resistivity at depth. Although the transition is rapid near the estimated depth of the firstmodified bank slope, it also is coincident with the groundwater level measured in piezometer PZ-4. Currently (2013), it is unknown if the indicated changes in resistivity at these elevations was the effect of saturation of the underlying sediments or caused by the compacted-core bank.

\section{Introduction}

Understanding the spatial characteristics of leakage from canals is critical to effective management and use of water resources for irrigation and hydroelectric purposes. Canal leakage in some parts of Nebraska is the primary source of water for groundwater recharge and helps maintain the base flow of streams (Hobza and Andersen, 2010; Luckey and Cannia, 2006). In these areas, canal leakage helps maintain groundwater supplies for domestic and agricultural uses. In other instances, surface-water supplies depend on the streamflow of the Platte River and the available water stored in upstream reservoirs, so water managers seek to minimize conveyance losses, including canal leakage, which can be critical in times when surface water is in short supply. In both cases, mapped geology beneath canals allows managers to better predict locations prone to canal leakage. Knowledge of leakage-prone areas facilitates planning and design of mitigation and management strategies, such as the placement of an 
impermeable canal liner to minimize conveyance losses or intentional groundwater recharge.

The U.S. Geological Survey (USGS), in cooperation with the Central Platte Natural Resources District (CPNRD) and Nebraska Public Power District (NPPD), used capacitively coupled (CC) resistivity techniques for continuous resistivity profiling to map near-surface lithologies near and underlying the Cozad, Thirty-Mile, Orchard-Alfalfa, Kearney, and Outlet Canals. In addition, direct-current (DC) resistivity surveys were used along a stretch of the Outlet Canal to identify potential seepage mechanisms. The near-surface lithologies beneath the Thirty-Mile, Cozad, Orchard-Alfalfa, Kearney, and Outlet Canals (fig. 1) can have large ranges in hydraulic conductivity and leakage potential. Mapping the sediments underlying irrigation canals can help Federal, State, and local water managers better understand the spatial variability of the canal leakage and potential for embankment seepage.

\section{Background}

The CPNRD has been involved in the development of an integrated water-management plan (IMP) to balance surfacewater and groundwater supply and demand. The IMP was first adopted in 2009 and later revised in 2012 (Central Platte Natural Resources District, 2012). As part of their IMP, the CPNRD (fig. 1) has been involved with ongoing numerical groundwater-flow modeling efforts to understand the effects of specific groundwater-management practices on streamflow. The Platte River Cooperative Hydrology Study (COHYST, http://cohyst.dnr.ne.gov/) was begun as a major component of a three-State Cooperative Agreement between Nebraska, Colorado, and Wyoming. Tasks of COHYST included collection of additional hydrologic data and construction of numerical groundwater-flow models for use in support of regulatory and management decisionmaking along the Platte River valley. Objectives of COHYST were to develop tools and datasets that will assist water managers in meeting their obligations for streamflow, analyzing proposed activities to improve streamflows for endangered and threatened species, assisting Natural Resources Districts (NRDs) with regulation and management of groundwater, and to provide a basis for Nebraska to establish and implement integrated groundwater and surface-water policies and procedures (Cooperative Hydrology Study, 2013). In addition to the COHYST modeling effort, a local Dawson County groundwater model was constructed by the CPNRD to address groundwater-management issues in the western part of the CPNRD, which has been declared "over-appropriated" with respect to groundwater use. The Dawson County groundwater model stretches from Kearney, Nebr., to west of the CPNRD western boundary on both sides of the Platte River (fig. 1).

For any groundwater-flow model to accurately simulate current or future groundwater and surface-water interactions in the central Platte River valley, understanding the distribution of canal leakage is imperative. Estimates of irrigation-system loss for many of the canal systems in the central Platte River valley are not well-constrained, and the interaction between irrigation canals and the groundwater system within the central Platte River valley at this time is not well-understood. For some canal systems in the COHYST model area, estimates for canal leakage were based only on an annual total system loss, which either was estimated from diversion data (Carney, 2008) or was assumed to be 40 percent of the total diversions (Peterson, 2007). Recharge from canal leakage was, in these cases, assumed to be distributed uniformly along the entire length of the canal. During wet years, some canal reaches may receive inflow from groundwater near their diversion points (Duane Woodward, Central Platte Natural Resources District, oral commun., 2011).

Some canals in the study area supply both hydroelectric and irrigation projects; therefore, such canals are maintained to minimize conveyance losses. The NPPD owns and operates a series of dams, reservoirs, and canals along a 240-kilometer $(\mathrm{km})$ stretch of the Platte River valley (Nebraska Public Power District, 2013). Focused seepage along the bank toe (lowest part of the canal embankment) of some canals not only increases water losses, but may also be a safety concern. Areas of focused seepage have raised concerns among NPPD water and canal managers, and without knowledge of the subsurface, applying mitigation actions, such as the installation of an impermeable liner or a slurry wall over the affected canal reach, can be extremely expensive (Edward Dekleva Jr., Nebraska Public Power District, oral commun., 2013).

Reaches of Kearney Canal, within the City of Kearney, and of Outlet Canal, southwest of North Platte, Nebr. (fig. 1), have been identified by NPPD personnel as having seepage through canal embankments that poses a potential hazard: bank instability. Focused embankment seepage at Kearney Canal prompted the installation of a drain at the toe of the canal bank. This drain has alleviated the hazard, but nearby monitoring wells still indicate seasonal rises of 1 meter (m). Because the seepage area along Kearney Canal is located within a populated area, mitigation may be needed to prevent potential safety hazards (Jeffrey Shafer, Nebraska Public Power District, oral commun., 2012).

NPPD also has identified locations along the Outlet Canal (fig. 1), of focused seepage through canal embankments downgradient of the canal. A relation between seepage rates and canal-flow rates is suspected. The Outlet Canal originally was constructed with compacted local materials creating what was locally referred to as a "core bank." In 1938 and 1945, the canal was widened to increase the conveyance capacity. Each time the canal was widened, the width and height of the compacted-core bank were reduced. Starting in August 2010, the size of seeps at the northern toe of the canal bank have increased, inundating adjacent areas. Increased seepage may be the result of the reduced width of the compacted core, or preferential flow paths or macropores that may have developed during drier periods (Edward Dekleva Jr., Nebraska Public Power District, written commun., 2012). 


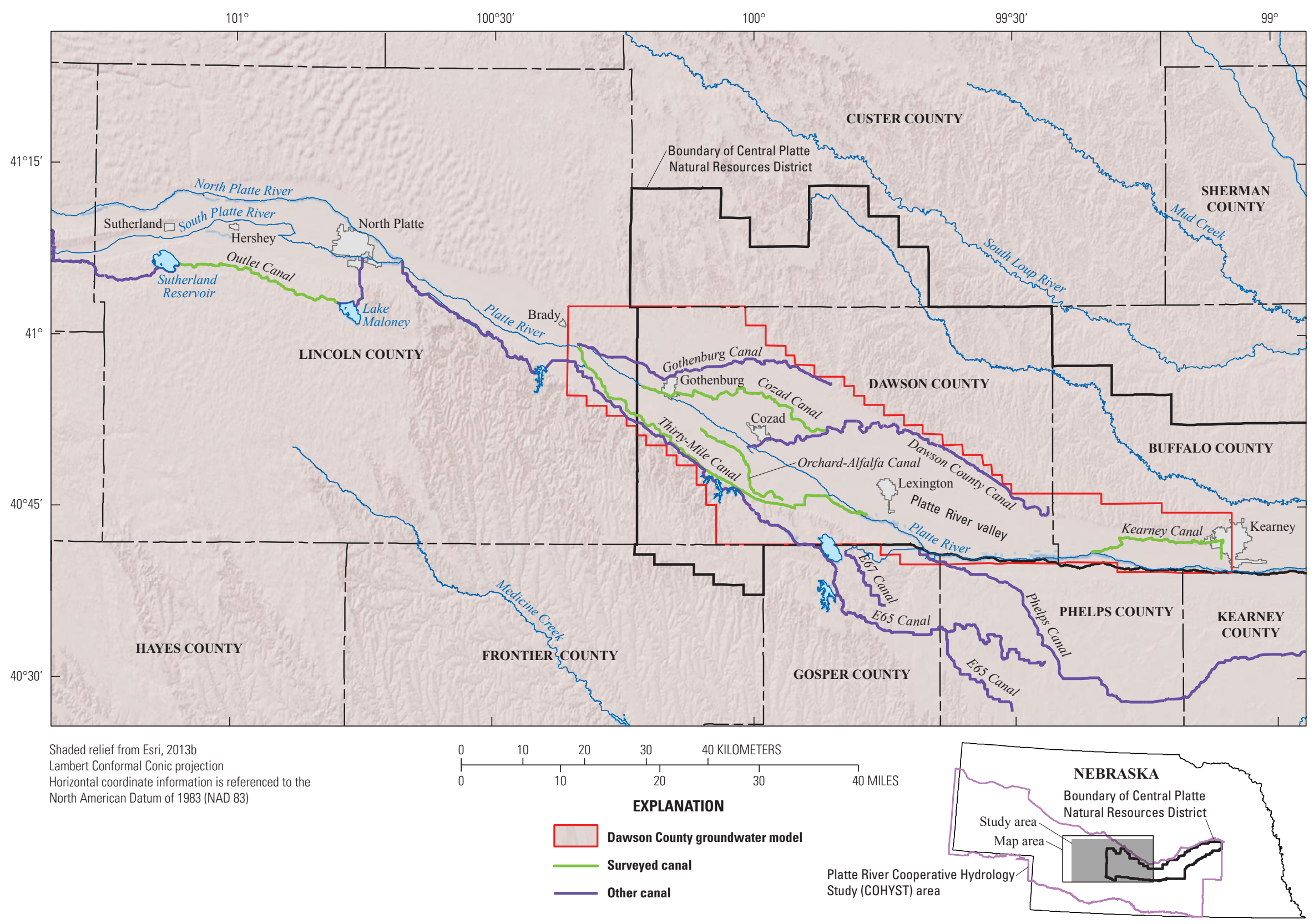

Figure 1. Location of study area and canals, where capacitively coupled and direct-current resistivity profiles were collected. 
Resistivity Surveys of Cozad, Thirty-Mile, Orchard-Alfalfa, Kearney, and Outlet Canals in Nebraska

\section{Purpose and Scope}

This report presents the final results from CC resistivity surveys acquired along 84 linear kilometers $(\mathrm{km})$ of canals in the study area collected from the spring of 2012 and 2013. The CC-resistivity results are presented as two-dimensional, layered-earth resistivity cross sections that extend to approximately $8 \mathrm{~m}$ below land surface.

A more detailed geophysical investigation was completed in April 2012 along a 5-km reach of Outlet Canal southwest of North Platte, Nebr., and CC- and DC-resistivity was used to examine the condition of the compacted-core bank structure and characterized other potential controls on focused areas of seepage. CC-resistivity data collected along the $5-\mathrm{km}$ study reach are compared with DC-resistivity data collected near a selected seep [Outlet Canal mile post (MP) 15.55] along 3 separate profiles. DC-resistivity results are compared to a schematic cross section showing the original Outlet Canal north embankment and modifications to its compacted-core bank structure. The inverted-resistivity data collected at selected reaches of all canals are compared with continuous sediment cores and direct-push electrical conductivity (EC) measurements. Continuous sediment-core descriptions and direct-push EC logs also are provided in this report.

\section{Previous Studies}

The approach used in this report is similar to previous studies conducted in western Nebraska. Ball and others (2006) used CC and water-borne DC resistivity to assess the spatial variability of canal leakage on Tri-State and Interstate Canals in the North Platte Natural Resources District (not shown on map). Burton and others (2009) expanded the study to include more than $635 \mathrm{~km}$ of CC resistivity-surveyed irrigation canals and reprocessed previously collected CC resistivity data using newly developed, in-house processing software, which greatly aided in the quality control and analysis of large amounts of georeferenced data collected along a sinuous path.

Other studies have applied similar tools and approaches to assess the integrity of engineered structures, such as levees, and to map the subsurface beneath these structures (Burton and Cannia, 2011; Gillip and Payne, 2011; Asch and others, 2008). Asch and others (2008) used DC and CC resistivity to identify the extent and thickness of sand and clay lenses underlying levees along the American River at Sacramento, California. Gillip and Payne (2011) collected CC resistivity data and continuous sediment cores on top of a levee near Conway, Arkansas, along the Arkansas River.

\section{Description of Study Area}

The study area includes reaches of selected irrigation and hydroelectric supply canals in Kearney, Dawson, and Lincoln Counties, Nebr. The study area extends from approximately $13 \mathrm{~km}$ southwest of North Platte, Nebr., to Kearney, approximately $160 \mathrm{~km}$ to the east (fig. 1). The study area lies within the Great Plains physical province (Fenneman and Johnson, 1946), and is located within the Platte River valley (fig. 1), with edges extending to the adjacent uplands to the north and south, and with west-east extent from Lincoln County to Kearney County, respectively (fig. 1). The Platte River valley is the predominant landform in the study area, whereas a major subdominant landform is the loess-covered upland that flanks the Platte River valley to its north and south. These loess-covered uplands (hereinafter referred to as "uplands") consist of dissected plains, sand hills, and bluffs.

Land use within the study area primarily is agricultural with much of the cropland being irrigated. Groundwater-fed center-pivot or gravity irrigation systems supply corn and soybean production that dominates all water use in the central Platte River valley. Surface-water irrigation also is prevalent but primarily located in the western part of the study area. Major surface-water canals providing water for irrigation or hydropower, or both, include Cozad, Kearney, Thirty-Mile, Orchard-Alfalfa, Outlet, Gothenburg, Dawson County, E65, E67, Phelps (fig. 1), Elm Creek (Peterson, 2007), and Central Nebraska Public Power and Irrigation District (CNPPID) Supply Canal (not shown on map) (Carney, 2008).

The climate is characterized by cold winters and warm summers typical of mid-continent locations (Carney, 2008). Mean monthly temperatures ranged from -3.7 degree Celsius $\left({ }^{\circ} \mathrm{C}\right)$ in January to $24.3^{\circ} \mathrm{C}$ in July at Gothenburg, Nebr., during 1895 to 2009 (National Oceanic and Atmospheric Administration, 2010). Low humidity, abundant sunshine, and persistent winds contribute to high rates of evaporation (Gutentag and others, 1984). Precipitation is variable from east to west across the study area with more arid conditions occurring to the west. Gothenburg, Nebr. (fig. 1), which is approximately in the center of the study area, had an average annual precipitation of 55.7 centimeters per year (cm/yr) from 1895 to 2009 (National Oceanic and Atmospheric Administration, 2010). Approximately 70 percent of the precipitation is received during the growing season from April through August (Carney, 2008).

\section{Description of Irrigation Canals}

This section of the report describes the physical and flow characteristics, including the estimated seepage, of each irrigation canal that was surveyed. Unless stated below, all relevant information for each canal is summarized in table 1 . The actual acres irrigated may be less than those reported in table 1 because crop water demands are at times supplemented with groundwater irrigation instead of surface water.

The NPPD operates two of the canals surveyed in this study. Kearney Canal is operated by NPPD for the purposes of irrigation and power production. Outlet Canal is part of the Sutherland project, which is supplied by water diverted from the North Platte River at Keystone Diversion (not shown on map) for energy production at the Gerald Gentleman Power Station (not shown on map) and a hydroelectric plant at North Platte (Carney, 2008). Outlet Canal begins at the eastern 
Table 1. Irrigated area, maximum flow rate, average annual diversion, and estimated seepage of selected canals in central Nebraska.

[Data from Lindburg (2005). NA, not applicable; >, greater than; not calculated, diversion data not compiled or calculated]

\begin{tabular}{lcccc}
\hline \multicolumn{1}{c}{ Canal } & $\begin{array}{c}\text { Irrigated area, } \\
\text { in hectares }\end{array}$ & $\begin{array}{c}\text { Maximum flow rate, } \\
\text { in cubic meters per second }\end{array}$ & $\begin{array}{c}\text { Average annual diversion, } \\
\text { in cubic meters }\end{array}$ & $\begin{array}{c}\text { Estimated seepage, } \\
\text { in cubic meters }\end{array}$ \\
\hline Cozad & 6,550 & 7.93 & $2.60 \times 10^{7}$ & $9.62 \times 10^{6}$ \\
Thirty-Mile & 5,340 & 9.06 & $4.45 \times 10^{7}$ & $1.36 \times 10^{7}$ \\
Orchard-Alfalfa & 1,750 & 2.41 & $1.03 \times 10^{7}$ & $3.33 \times 10^{6}$ \\
Kearney & 1,970 & 9.77 & $2.32 \times 10^{7}$ & $1.16 \times 10^{7}$ \\
Outlet & NA & $>42.5$ & not calculated & $3.70 \times 10^{7}$ \\
\hline
\end{tabular}

end of Sutherland Reservoir and ends approximately $31 \mathrm{~km}$ downstream at Lake Maloney (fig. 1). Outlet Canal typically has peak flows that exceed 42.5 cubic meters per second $\left(\mathrm{m}^{3} / \mathrm{s}\right)\left[1,500\right.$ cubic feet per second $\left.\left(\mathrm{ft}^{3} / \mathrm{s}\right)\right]$. Flows are gradually increased in spring and typically are maintained through September. Between peak flow periods, flows typically are maintained at about $14.0 \mathrm{~m}^{3} / \mathrm{s}\left(500 \mathrm{ft}^{3} / \mathrm{s}\right)$ or less; however, drought conditions prompted managers to decrease flows to nearly zero during 2004 to 2010 (Tetra Tech, 2012).

\section{Geology and Hydrogeology}

Previous investigations have described the geology and occurrence of groundwater within the study area (Darton, 1898, 1905; Lugn and Wenzel, 1938; Waite and others, 1949; Peckenpaugh and Dugan, 1983; Goeke and others, 1992). Condon (2005) described the geologic history of the Platte River Basin, which includes the study area. Cannia and others (2006) created a hydrostratigraphic framework and characterized underlying aquifers of the CPNRD and surrounding areas that was used in recently published COHYST groundwaterflow models (Carney, 2008; Peterson, 2007), which include all or parts of the study area.

The study area overlies the High Plains aquifer system, which consists of hydraulically connected deposits of Quaternary and Tertiary age (Gutentag and others, 1984). The Tertiary-age deposits in the study area consist of the Ogallala Group (hereinafter referred to as the Ogallala) and may include the upper part of the White River Group. Quaternary-aged deposits within the Platte River valley primarily are alluvium, which includes flood-plain deposits, but also include windblown deposits of loess and eolian sand. In the study area, the High Plains aquifer system is underlain by the regional confining units composed of the Brule Formation of the White River Group, the Cretaceous-age Pierre Shale, and the Niobrara Formation of the Colorado Group.
The Ogallala is a poorly sorted mixture of sand, silt, clay, and gravel (Condra and Reed, 1943). The Ogallala generally is unconsolidated or weakly consolidated but can contain layers of sandstone cemented by calcium carbonate. The Ogallala reaches a maximum thickness in the study area of more than $120 \mathrm{~m}$ in western Dawson County (Irons and others, 2012). Multiwell, 96-hour aquifer tests conducted in Dawson County showed that the hydraulic conductivity of the Ogallala in Dawson County was about $3.5 \times 10^{-5}$ to $3.9 \times 10^{-5}$ meters per second $(\mathrm{m} / \mathrm{s})$ (Irons and others, 2012).

The near-surface geology of the uplands consists of windblown deposits of loess or eolian sand that overlie localized alluvium or directly in contact with the Ogallala. Depths to groundwater in the upland areas can vary from less than $10 \mathrm{~m}$ in isolated small sand-and-gravel pockets to more than $50 \mathrm{~m}$ (Irons and others, 2012). In the lowlands, the near-surface geology consists of Quaternary-age deposits of alluvial sand and gravel with discontinuous lenses of silt and clay and floodplain deposits. Groundwater typically is present throughout the alluvium and can vary in depth from less than $1 \mathrm{~m}$ near the major rivers to more than $10 \mathrm{~m}$ near the walls of the Platte River valley.

Where sufficient saturated deposits are present in the central Platte River valley, the Quaternary alluvium forms the primary aquifer because of their widespread distribution, shallow depths, and their ability to yield sufficient groundwater supplies to high-capacity wells. Quaternary-age deposits often overlie deposits of Pliocene-age sand and gravel, which cover much of the study area (Condon, 2005). These older fluvial deposits exist locally beneath some of the upland deposits but have not been extensively mapped. Multiwell, 96-hour aquifer tests indicate the hydraulic conductivity of the alluvium is roughly an order of magnitude greater than the Ogallala at $8.5 \times 10^{-4} \mathrm{~m} / \mathrm{s}$ to $1.0 \times 10^{-3} \mathrm{~m} / \mathrm{s}$ (Irons and others, 2012). Wells completed in the alluvial aquifer underlying the Platte River valley sustain yields ranging from about 3,000 to 5,700 liters per minute $(\mathrm{L} / \mathrm{min})$ (800 to 1,500 gallons per minute) (Waite and others, 1949). 


\section{Methods of Investigation}

\section{Overview of Resistivity Method}

Resistivity is an intrinsic material property that is defined by resistance to the flow of electric current in that material. Measurements of this property are made by injecting a known current into the subsurface using two current electrodes and measuring the resulting voltage difference between two potential electrodes. Based on Ohm's Law, the resistance is computed by taking the ratio of the measured voltage and the transmitted current. The apparent resistivity of the material, expressed in ohm-meters (ohm-m), can then be determined by multiplying each resistance value by the corresponding geometric factor, which is based on the electrode geometry and spacing.

The main factors that affect the resistivity of a material are the amount of interconnected pore water present, the water quality [level of total dissolved solids (TDS)], and the amount of mineralogical clay present. In the unsaturated zone, if no mineralogical clay is present, a fine-grained material (for example, silt or fine sand) generally will retain more interconnected pore water because of capillary forces than does a coarse-grained material (for example, coarse sand or gravel). The fine-grained material will therefore have a lower resistivity compared to coarser-grained materials. Water quality is an important factor because the concentration of ions in the water affects its ability to conduct electricity. Materials containing water with high TDS will have a lower resistivity compared to materials containing water with low TDS. The presence of even a small amount of clay minerals can dramatically decrease the overall bulk resistivity of a material because current is conducted both through the pore fluids (electrolytically) as well as through cation exchange (electronically). Because of the relations among grain size, clay content, and resistivity, the resistivity method can be a useful tool in differentiating lithologies, and thereby enables one to predict relative rates of recharge to an unconfined, alluvial aquifer. Butler (2005), Reynolds (1997), and Sharma (1997) provide more detailed descriptions of the resistivity method and resistivity values for common geologic materials.

\section{Capacitively Coupled Resistivity Methods}

\section{Data Acquisition}

All CC resistivity datasets were acquired in spring 2012 before the onset of water delivery for Cozad, Thirty-Mile, Orchard-Alfalfa, and Kearney Canals, with one exception: the eastern end of Thirty-Mile Canal was surveyed in spring 2013 (fig. 2). With the exception of reaches of Cozad Canal and Outlet Canal, all CC resistivity data were collected when the canals were dry. For the excepted reaches, $\mathrm{CC}$ resistivity data were collected on top of the canal embankment. In the spring of 2012, CC resistivity data at Outlet Canal were collected along a 5-km reach near the seep at Outlet Canal MP 15.55 (fig. $3 A$ ). Two passes were collected along the north and south edges of the north access road along the canal and a third pass was collected along the toe of the north bank of Outlet Canal (fig. $3 B$ ).

The CC resistivity data were acquired with the Geometrics OhmMapper TR5 (Geometrics, Inc., San Jose, Calif.) towed behind an all-terrain vehicle (ATV). This dipole-dipole array system comprised five receiver dipoles, equivalent to five potential electrode pairs, and one transmitter dipole, equivalent to a current electrode pair (fig. 4). Each dipole consisted of a 5-m cable attached to each end of an electronics unit, yielding dipole lengths of $10 \mathrm{~m}$. The resultant towed array length was on the order of $50 \mathrm{~m}$.

The transmitter, located at the rear of the array, was attached to the receivers by a nonconductive rope $(5 \mathrm{~m}$ long for this survey), and transmitted an alternating current at a frequency of 16.5 kilohertz $(\mathrm{kHz})$. Current was transmitted into the ground through the use of capacitance, which negates the need for the electrodes to be in direct contact with the ground and thus allows for more efficient and faster data acquisition. With the wire in each dipole cable and the ground acting as the opposing conductor "plates" of a capacitor, the insulating sheath enclosing the wire and the air space between the dipole cable and the ground functioned as the insulator between the plates (Geometrics, 2001).

Each receiver dipole sampled the subsurface to a particular depth based on its length and distance from the transmitter dipole. To attain the survey objective, the survey was designed for the optimal compromise between vertical and horizontal resolution and maximum depth of investigation by varying the geometry (dipole and rope lengths) of the array. The CC resistivity and differential global positioning system (DGPS) data were acquired at a rate of 1 hertz $(\mathrm{Hz})$ with the ATV traveling from 3 to 5 kilometers per hour. For further details on the CC resistivity method and acquisition system, refer to Ball and others (2006), Geometrics (2001), Lucius and others (2008), and Timofeev and others (1994).

All CC resistivity data were acquired using an integrated DGPS. All DGPS data were collected with a Trimble DSM 232 (Trimble Navigation Ltd., Sunnyvale, Calif.) with the OmniSTAR (OmniSTAR, Inc., Houston, Texas) High Precision (HP) subscription service. The vertical and horizontal accuracies provided by the HP service typically are less than \pm 15 centimeters $(\mathrm{cm})$ and $\pm 10 \mathrm{~cm}$, respectively (OmniSTAR, 2005).

There were several obstacles to acquiring continuous data along canals. For data acquired from the bed surface within the canals (as opposed to from the top of the canal bank), the obstacles included concrete check structures (removable dams used to manage water levels in the canals) and weirs, low or impassible bridges, fences, underground siphons (located where canals cross surface-drainage features), and extended sections of rough or sharp concrete blocks or trash that could cause damage to the system. If these obstacles were so frequent that efficient acquisition of data was impeded 


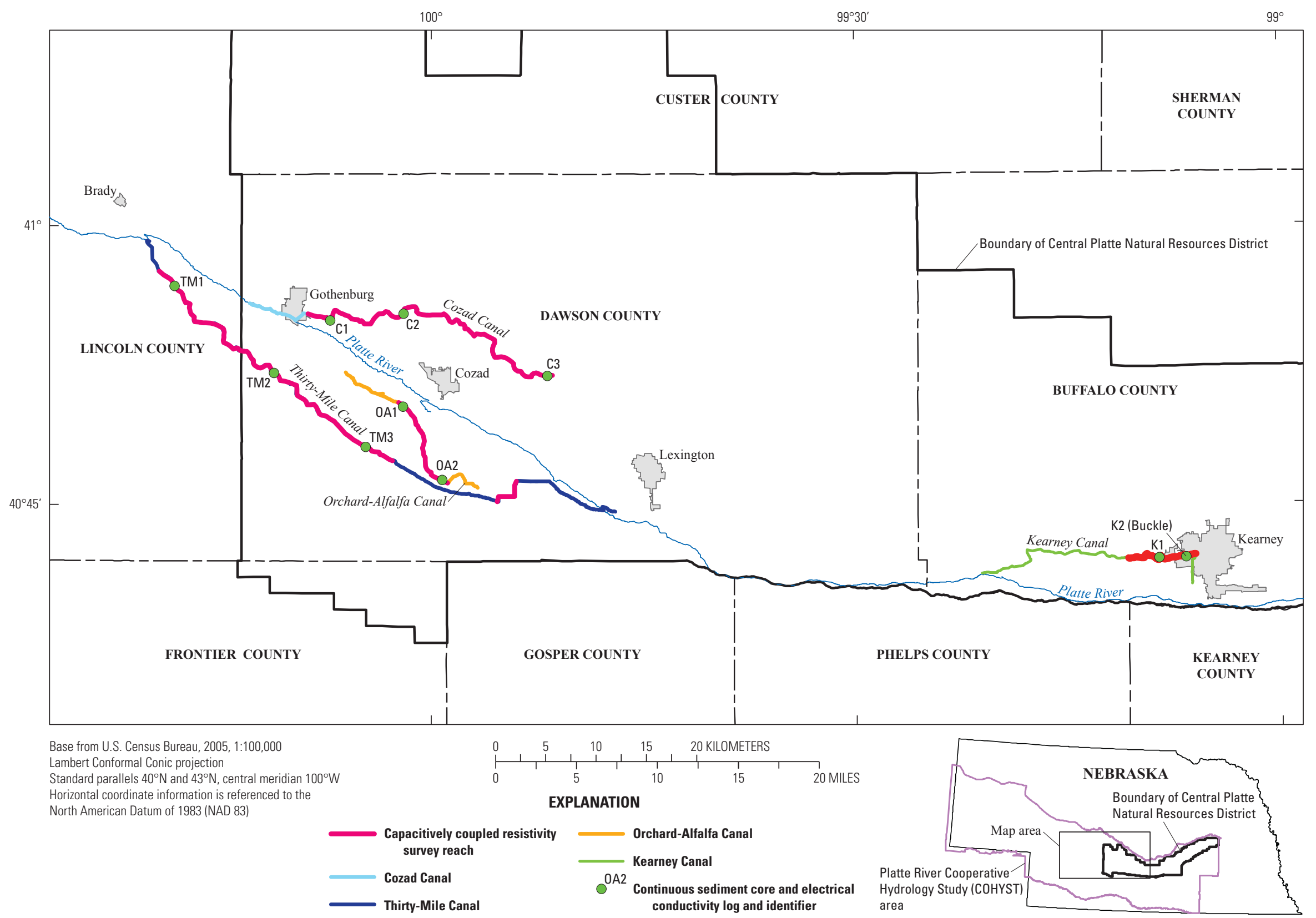

Figure 2. Location of continuous sediment cores and canal reaches surveyed with capacitively coupled resistivity methods in Dawson and Buffalo Counties, Nebraska. 


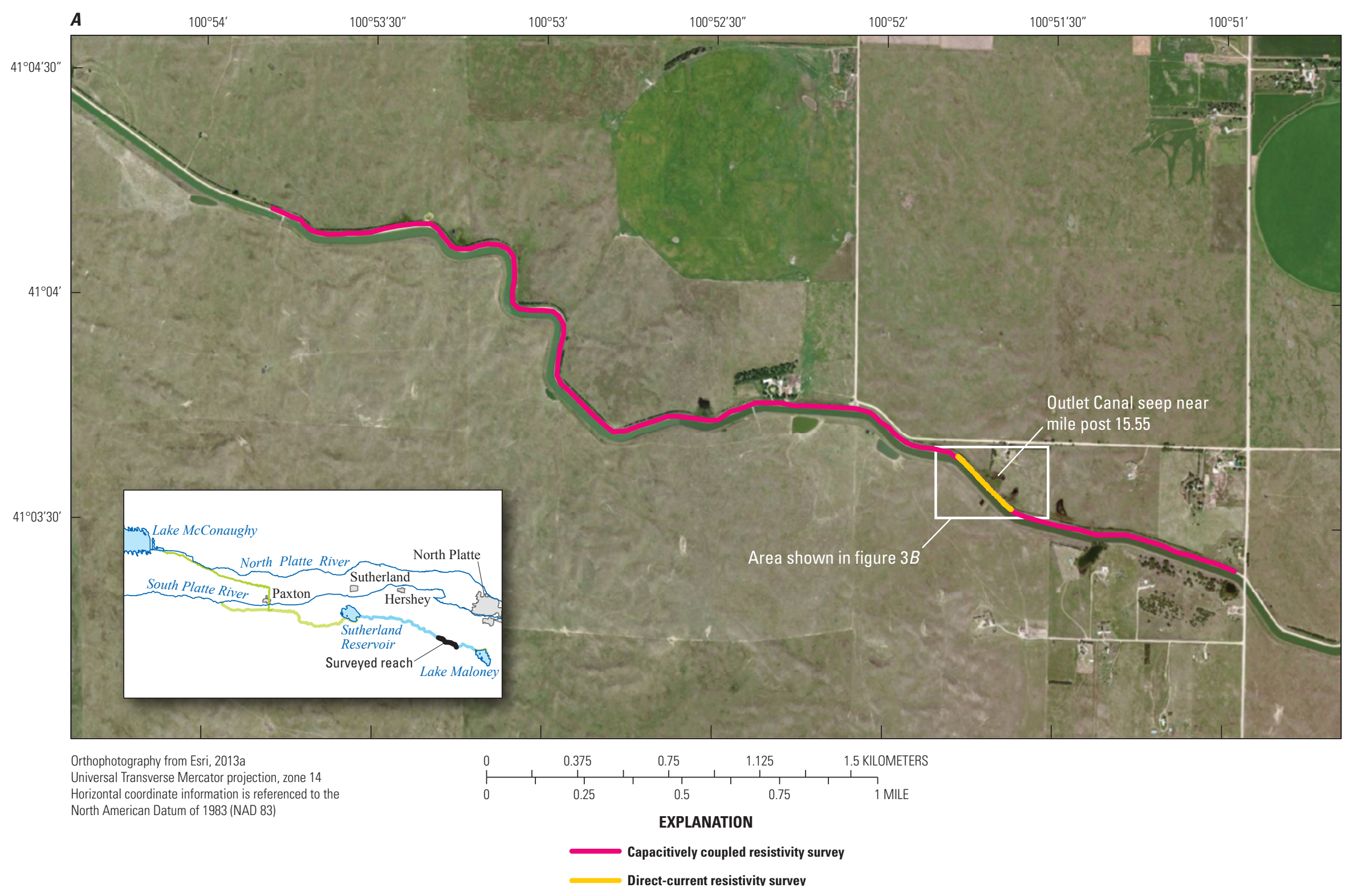

Figure 3. Location of $A$, capacitively coupled and direct-current resistivity surveys and $B$, continuous sediment cores and five direct-current resistivity lines collected on the north side of Outlet Canal near a seep near Outlet Canal mile post 15.55. 


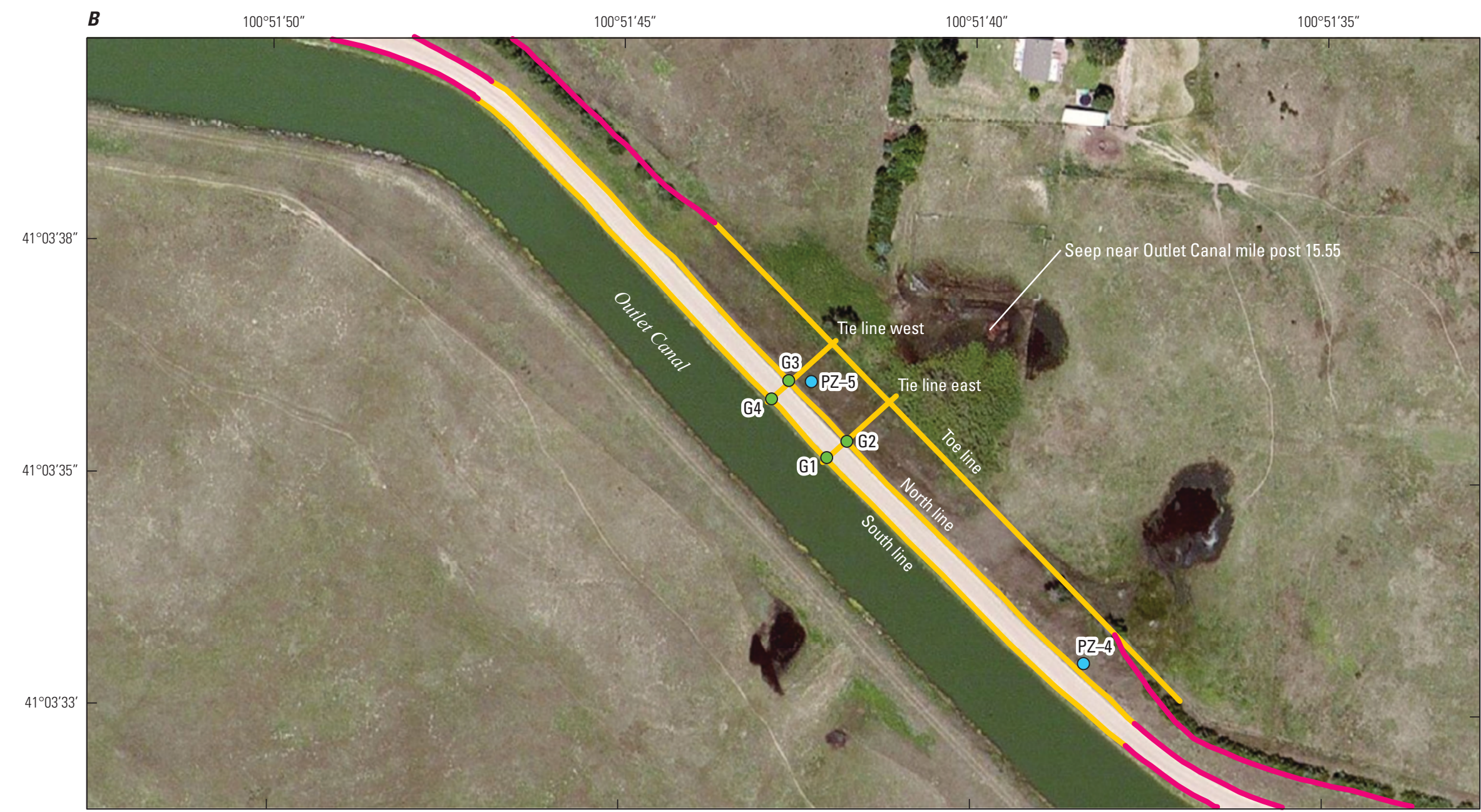

Orthophotography from Esri World Imagery, 2013 Universal Transverse Mercator projection, zone 14 Horizontal coordinate information is referenced to the North American Datum of 1983 (NAD 83)

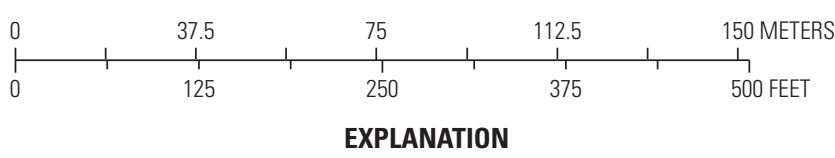

Figure 3. Map showing ILocation of $A$, capacitively coupled and direct-current resistivity surveys and $B$, continuous sediment cores and five direct-current resistivity lines collected on the north side of Outlet Canal near a seep near Outlet Canal mile post 15.55.—Continued

\section{$\mathrm{O}^{\mathrm{G} 1}$ Continuous sediment core and electrica PZ-4 conductivity log and identifier $\mathrm{O}^{\text {Piezometer and identifier }}$}

$\begin{array}{cl}\text { Capacitively coupled resistivity survey } & \mathrm{O}^{\mathrm{G} 1} \text { Continuous sediment core and electrical } \\ \text { Direct-current resistivity survey } & \mathrm{PZ}-4 \text { conductivity log and identifier } \\ & \bigcirc\end{array}$




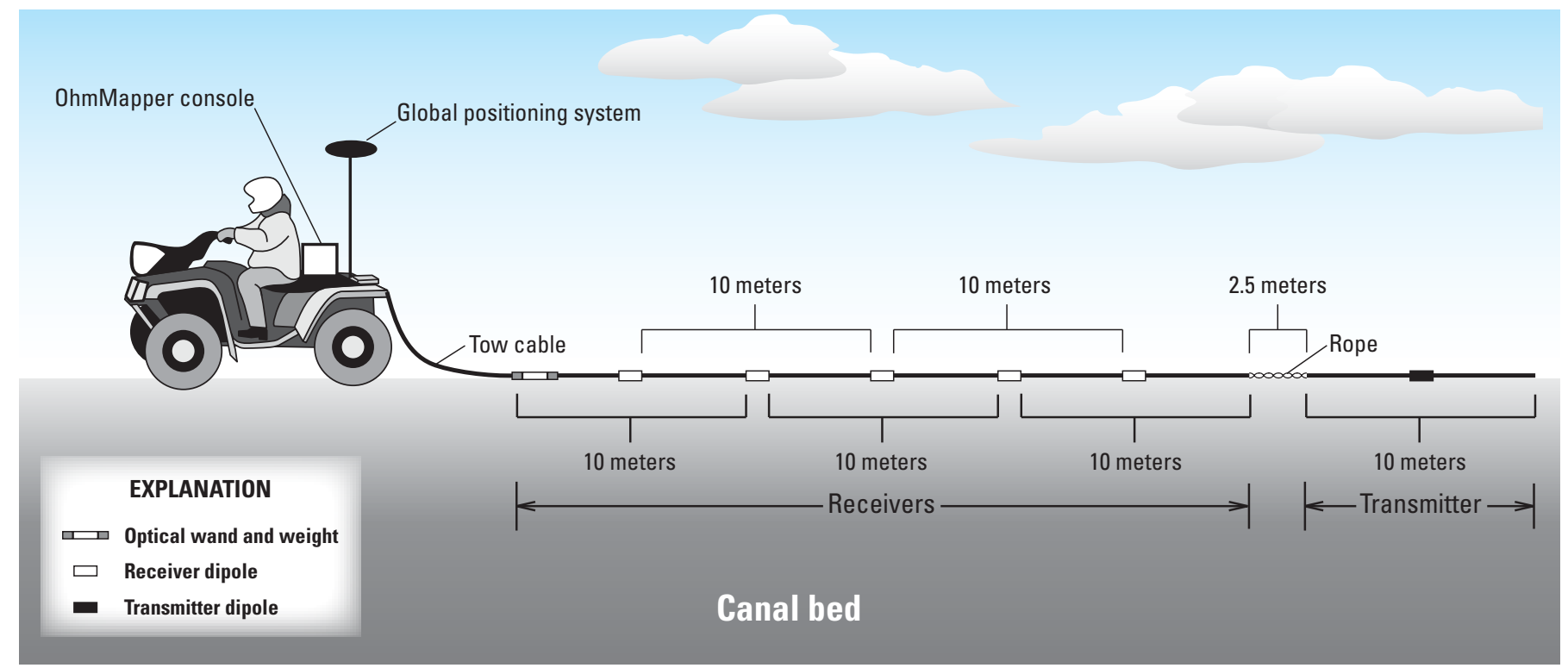

Not to scale

Figure 4. Capacitively coupled resistivity-system setup and geometry (modified from Ball and others, 2006).

along an area within the canal, then small sections of the canal were bypassed. Standard operating procedures for concrete checks, weirs, and extended areas where it would be unsafe for the towed array to be pulled over (that is, instances where it was not necessary to winch the ATV completely out of the canal channel) were to reel the array onto the back of the ATV, drive the ATV across the obstacle, and lay out the array on the other side. At each siphon, the section between the intake and outflow was bypassed. For surveys along the top of the canal bank, coverage gaps exist because of county road or highway crossings.

\section{Data Processing and Inversion}

The raw binary data files were downloaded from the OhmMapper instrument using Geometrics Magmap2000 software, version 4.94 (Geometrics, 2013). The binary files were imported into a pair of unpublished USGS GPS and OhmMapper data-processing software programs (GPSpathtool and OhmBin, respectively; Joseph Vrabel, written commun., 2012). Upon initial import of a raw binary file, GPSpathtool allowed the user to enter the GPS antenna height, to define the nature of the survey (for example, a single pass with a single geometry or multiple passes over the same line with multiple geometries), and to edit the array geometry (for example, GPS-array offset, dipole lengths, or rope length). The geographic coordinates in the binary file automatically are projected to the appropriate Universal Transverse Mercator (UTM) zone in North American Datum of 1983 (NAD 83) meters, and the position and elevation of the center of each transmitter-receiver pair for every measurement is interpolated and extrapolated from the DGPS data stream. Bad locational data were rejected based on the GPS quality factor and by graphically selecting data points. A single path was then fitted to the accepted GPS data. The discrete points were mapped, or projected, to the path fit. The typical processing procedure used was to remove data with a GPS quality factor of zero (indicative of complete loss of signal lock because of overhead obstructions such as tree cover and bridges) and selective removal of data with a GPS quality factor of two (indicative that DGPS location had not converged to a horizontal accuracy less than $30 \mathrm{~cm}$ ) based on position relative to the general path trend. A quality factor of 4 is the optimal GPS quality factor, indicating that horizontal accuracy ranges from 5 to $30 \mathrm{~cm}$.

Outputs from GPSpathtool were imported into the OhmBin program, where the resistivity data were viewed and processed. Within the OhmBin program, all data can be viewed as either horizontal, down-distance line plots for each receiver or as contoured pseudosections of the apparent resistivity, measured voltage, calculated resistance (millivolts per milliamp), and transmitted current levels. The data were processed by (1) automatically removing data spikes using a single data-point-spike width and factor of 1.5 (defined below), (2) manually removing obvious data spikes in the voltage and resistance data, and (3) binning (or averaging) the data to a 5-m horizontal bin size. A single data-point-spike factor is defined as the ratio of a data point with its neighboring points. If a preset threshold is exceeded, then the point is removed. A single data-point-spike width and factor of 1.5 was chosen based on the high-frequency noise characteristics observed in the data. These parameters essentially created a low-pass filter that allowed for removal of the higher-frequency noise 
created by the movement of the system during acquisition and by nearby electromagnetic interferences (for example, electric fences). The 5-m bin size was chosen as a good compromise between the lateral heterogeneity expected in the subsurface in the survey area and the practical lateral resolution of CC resistivity measurements acquired with a 5-m half-dipole length.

The binned data were exported in a RES2DINV (Loke, 2009) file format that also can be read into the EarthImager 2D (Advanced Geosciences, Inc., 2008) inversion program. All CC resistivity data were inverted using the robust, finiteelement inversion method in EarthImager 2D (version 2.4.0, build 617; Advanced Geosciences, Inc., 2008). The robust method is based on the assumption of exponentially distributed errors and minimizes the combination of the data misfit and model instability (L1-norm parameter). The method typically works well on noisy datasets, which were common in this study because of cultural features such as electric fences and overhead powerlines. This method also resolves abrupt changes in resistivity (lithology) (Advanced Geosciences, Inc., 2008), which are common in alluvial systems. The inverted resistivity sections were then imported into Encom Profile Analyst (Pitney Bowes Software, North Sydney, Australia, http://www.encom.com.au/template2.asp? pageid $=16$ ), along with the lithologic and EC logs, for analysis and interpretation.

\section{Direct-Current Resistivity}

As part of a more detailed geophysical investigation, DCresistivity surveys were completed near the seep near Outlet Canal MP 15.55 in the spring of 2012. DC-resistivity measurements were collected along five profiles near Outlet Canal (fig. $3 B$ ). Three longitudinal profiles are parallel to the canal road, one on the south side of the road, one on the north side of the road, and one at the toe of the north embankment. Two transverse profiles were collected perpendicular to the canal to tie together the first three profiles. The two roadside profiles are about $300 \mathrm{~m}$ long, the toe profile is about $210 \mathrm{~m}$ long, and the two transverse profiles (each crossing three other profiles) are about $30 \mathrm{~m}$ long. The longitudinal profiles had electrodes at 1-m spacing, and the two transverse profiles had electrodes at 0.5 -m spacing.

The SuperSting R8 (Advanced Geosciences, Inc., Austin, Tex.) is a galvanically coupled, direct-current resistivity system with a digital data-collection system. Electrodes are driven about $20 \mathrm{~cm}$ into the ground with a constant distance separating the electrodes along a relatively straight line.

Electric current is applied to two of these electrodes, which produces an electric field in the earth. The potential of the electric field is measured between one or more pairs of other electrodes. Increasing the electrode spacing achieves a greater depth of investigation, but at a reduced resolution (Lucius and others, 2007). The Wenner-Schlumberger electrode configuration was used, with the longitudinal profiles having 112 electrodes and the transverse profiles about 64 electrodes. For parts of the longitudinal profiles extending beyond the available 112 electrodes, 28 electrodes were "rolled" (picked up from the trailing end of the line of electrodes and moved to the advancing end). The same control-unit acquisition settings were used for all five profiles.

The five profiles were topographically surveyed using a real-time kinematic (RTK) Leica System 1200 GPS system (Leica Geosystems, Norcross, Georgia). The first and last electrode of each line were surveyed, and additional electrode locations were surveyed along the line to capture horizontal trend and vertical relief. In addition to the electrode locations, other relevant features such as piezometer locations, watersurface elevations, and seeps also were surveyed. The GPS latitude and longitude coordinates were projected into UTM, zone 14N (NAD 83), as meters and into Nebraska State Plane Coordinate System (NAD 83) as U.S. survey feet. Elevations were tied to NPPD Outlet Canal Reference Monument no. 3, which uses the NPPD datum [which is offset $0.264 \mathrm{~m}$ above the North American Vertical Datum of 1988 (NAVD 88)]. Complications with GPS base-station configuration limited the achieved horizontal and vertical accuracies to $\pm 10 \mathrm{~cm}$.

The same version of EarthImager 2D (as used for $\mathrm{CC}$ resistivity data inversion) was used to process the SuperSting R8 measurements and the positional coordinates along the profiles to produce inversion models, which are estimates of the two-dimensional (2-D) distribution of subsurface electrical resistivity beneath the profile lines. The same inversion settings were used for all five DC-resistivity profiles. The unpublished USGS software ConvertToPA (Jeffrey Lucius, written commun., 2012) assigned Nebraska State Plane Coordinate System coordinates, in U.S. survey feet referenced to NAD 83, to the inversion model data. As was done with the CC-resistivity datasets, the inverted DC-resistivity sections were then imported into Encom Profile Analyst for analysis together with the CC resistivity, lithology, and EC logs.

\section{Continuous Sediment Cores and Direct-Push Electrical Conductivity Logging}

Fourteen continuous sediment cores were collected for ground-truthing and quality-assurance purposes using a tractor-mounted Geoprobe coring rig (Model 54TR, Geoprobe Systems, Salina, Kans.) (figs. 2 and $3 B$ ). Safety considerations led to core collection at the top of the canal bank rather than at the canal bed. Horizontal offsets (distance between the core and CC resistivity data) typically were less than $10 \mathrm{~m}$, and vertical offsets ranged from 0.5 to $3.5 \mathrm{~m}$. All cores were collected to the maximum depth, or refusal depth, of approximately $8 \mathrm{~m}$ below land surface (at the location where the core was collected). Coring locations were selected on the basis of trends or anomalies observed in the CC-resistivity sections to capture variability along each canal. Because the $\mathrm{CC}$ resistivity data were used as a reconnaissance tool, the cores were located in a more logical, strategic manner rather than a random sampling. A strategic coring plan ensured that the lateral variability observed in the resistivity profiles could be verified at core 
locations and interpreted accordingly; moreover, areas of concern were more properly sampled and visually characterized. Cores were collected, labeled, and later visually inspected and lithologically described. Detailed lithologic descriptions were later categorized into broader classifications using the Unified Soil Classification System (ASTM International, 2011) to facilitate the visual comparison of results. Differential laser leveling was completed to determine the elevation offset between the land surface on top of the canal bank (core location) and the canal bed.

After each core was collected, a direct-push electrical conductivity log was acquired in an undisturbed area near the core location using the Direct Image ${ }^{\circledR}$ EC system (Geoprobe Systems, Salina, Kans.) attached to the Model 54TR Geoprobe. The EC logging tool measured subsurface conductivity and probing speed simultaneously. A sensor was attached to the end of a steel drive rod, which was driven into the subsurface using a percussion hammer and a hydraulic slide. The deployed sensor consisted of a four-electrode Wenner array configuration with a total array length of 76 millimeters $(\mathrm{mm})$. The vertical resolution was $2 \mathrm{~cm}$ with a $20-\mathrm{Hz}$ sampling rate (Kejr, Inc., 2009). For graphical display in this report, vertical profiles collected as EC logs were converted from conductivity to resistivity units.

Before the collection of each EC log, a standard qualitycontrol test was performed on the field computer and the EC probe, consisting of an instrument calibration test and probe continuity and isolation tests. Before and after each test hole, an EC load test was completed using a test jig that simulates three different soil electrical conductivity values. The threshold limit for a successful test, indicating the EC system was functioning properly, was \pm 5 percent of each tested load value.

\section{Capacitively Coupled and Direct- Current Resistivity}

Results of the CC data collected for Cozad, Thirty-Mile, Orchard-Alfalfa, Kearney, and Outlet Canals are presented as inverted resistivity sections near sediment coring locations in figures 5 through 16. All CC-resistivity data, including the 5-m binned and vertically averaged data sets are available electronically with this report at http://pubs.usgs.gov/of/2014/1007/ downloads/. Inverted CC and DC data collected near Outlet Canal are presented in the Outlet Canal section of this report.

Maps of the vertically averaged resistivity (from CC resistivity surveys) are presented for Cozad, Thirty-Mile, and Orchard-Alfalfa Canals in figure 17A, and for Kearney Canal in figure $17 B$. The vertical average includes all resistivity data in the surveyed section, including the partial section extending from the top of the canal bank to the elevation of the canal bed, as well as the lower partial section beneath the canal-bed elevation. Maps of the vertically averaged resistivity can be used to interpret the relative leakage potential along the canals. Low leakage potential tends to be correlated with low average resistivity because it is often associated with finer grained materials (such as clay and silt), which have lower hydraulic conductivities. Highly resistive materials, on the other hand, are considered to have high leakage potential because higher resistivity tends to be associated with coarse-grained materials, such as coarse sand, that have higher hydraulic conductivities.

The results for all lithology and EC logs (displayed as resistivity) are shown alongside the corresponding CC resistivity data in figures 5 through 16 . The detailed lithologic descriptions for all 14 cores are presented in table 2. The detailed lithologic descriptions were combined into broader categories for display in figures 5 through 16 to aid in the visual comparison with and interpretation of the $\mathrm{CC}$ resistivity and $\mathrm{EC} \log$ results. The broader lithological categories were coded using the Universal Soil Classification System (ASTM International, 2011) and follow a similar classification scheme that was used in Ball and others (2006) and Burton and others (2009). The CC resistivity data, when compared to the EC logs (presented as resistivity), typically were well-correlated. In general, the EC logs show greater detail than the CC resistivity data can depict because the EC logs recorded data at depth increments of $2 \mathrm{~cm}$. Conversely, the $\mathrm{CC}$ resistivity data comprise five data points over an 8-m depth range, and because of the 5-m bin size, each data point is a lateral average across $5 \mathrm{~m}$. This relatively coarse sampling has a "smearing" effect on the positioning of the resistivity boundaries.

Since the data collection and processing variables used in this report match those used by Burton and others (2009) for canals surveyed in western Nebraska, comparisons of resistivity and therefore leakage potential can be made across the study areas. Common variables include the $\mathrm{CC}$ resistivity data-collection geometry and the 5-m horizontal bin size. The vertically averaged resistivity data, using a common resistivity scale that enables the direct comparison of the resistivity values, and an assessment of the relative leakage potential for all surveyed canals are shown in figures $17 A$ and $17 B$. In general, the alluvial sediments underlying canals in central Nebraska are finer-grained compared to western Nebraska, and therefore have a lower resistivity.

Generally, the highest measured resistivities in this report were recorded at the extreme upstream reaches of the canals where flood-plain deposits of silt and clay mantle coarser alluvial deposits of sand and gravel. The finer grained deposits gradually thicken as canals continue eastward and move further away from the Platte River. Across many surveyed reaches, the thickness of these finer grained deposits exceeded the 8 -m depth of investigation. 
A C1 Lithology and electrical conductivity-derived resistivity log

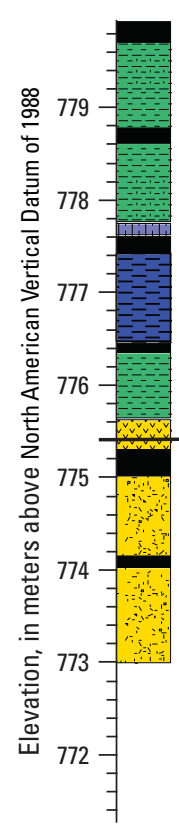


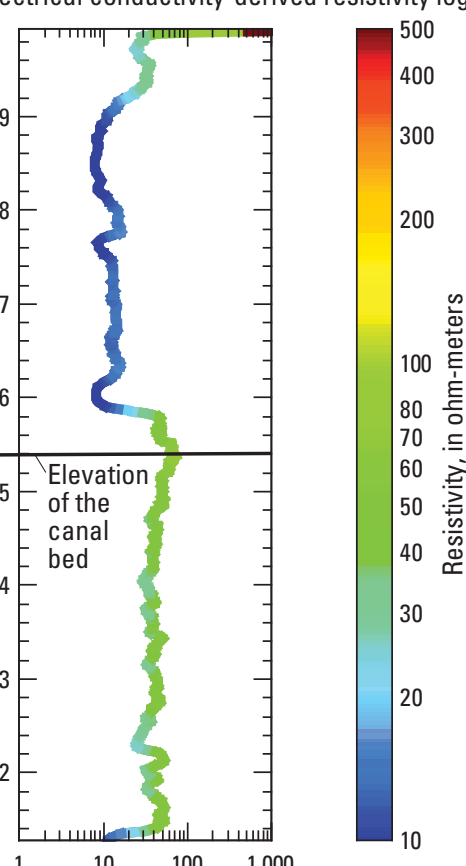

\begin{tabular}{|l|l|}
\hline \multicolumn{2}{|c|}{ EXPLANATION } \\
Lithology \\
Label & Description \\
NS & No sample \\
OL & Organic silty clay-clayey silt \\
CL & Clay-silty clay \\
ML & Sandy silt \\
SP & Sand, well sorted \\
SW & Sand, poorly sorted \\
& Canal location \\
Surveyed section of canal \\
Displayed section of canal \\
Continuous sediment core and \\
electrical conductivity log \\
and identifier
\end{tabular}

$\boldsymbol{B}$

Cozad Canal Easting, in meters

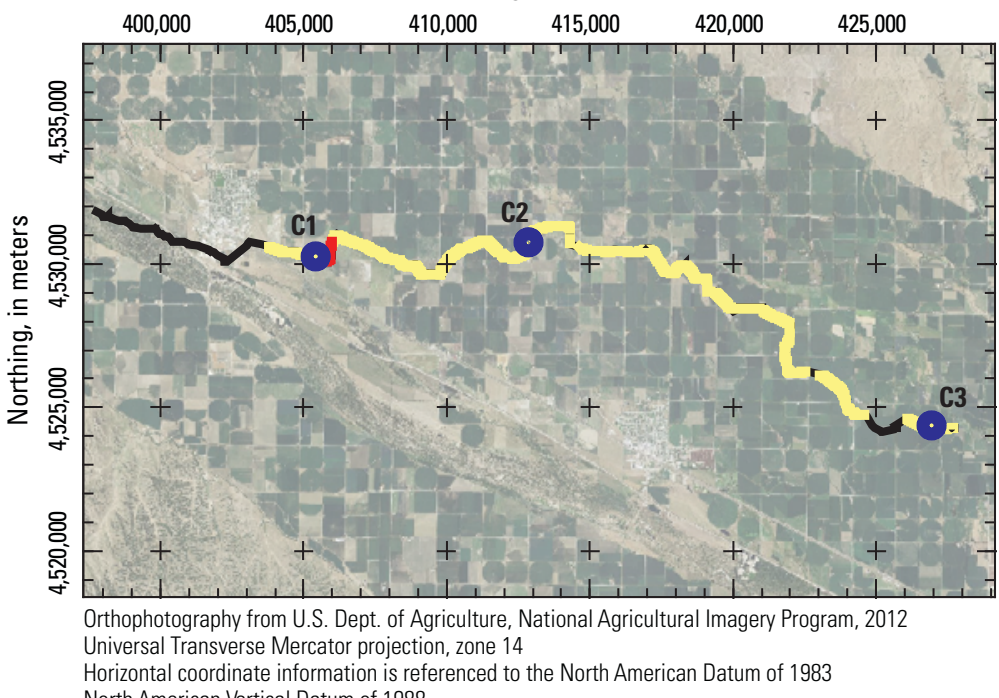
North American Vertical Datum of 1988

C Inverted capacitively coupled resistivity section

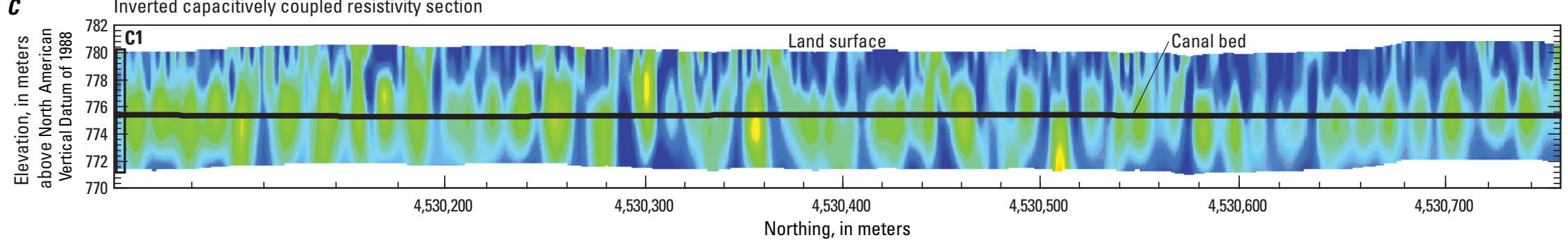

Northing, in meters

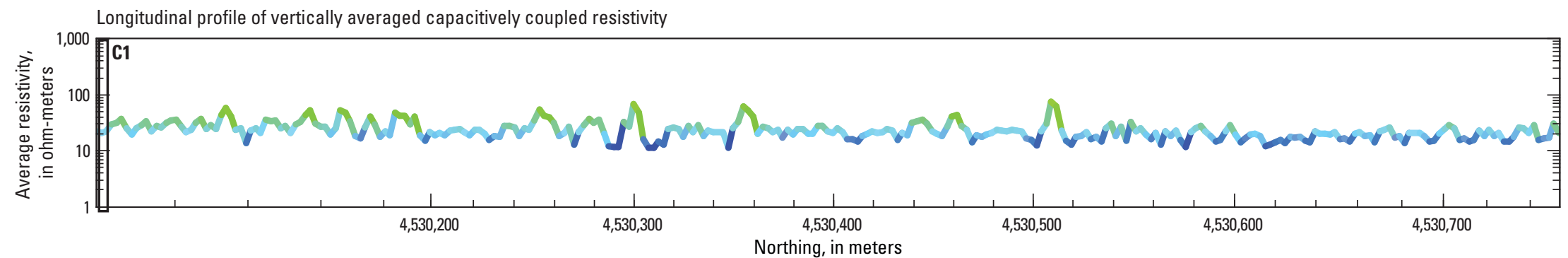

Figure 5. Comparison of capacitively coupled resistivity section and lithologic and electrical conductivity (EC) data from core C1. Survey results showing $(A)$ vertical profiles of lithologic and EC log data from core $C 1$ collected on the canal bank near Cozad Canal; $(B)$ location of canal, surveyed reaches, and displayed results; and $(C)$ inverted capacitively coupled resistivity section and vertically averaged resistivity profile. 
A C2 Lithology and electrical conductivity-derived resistivity log

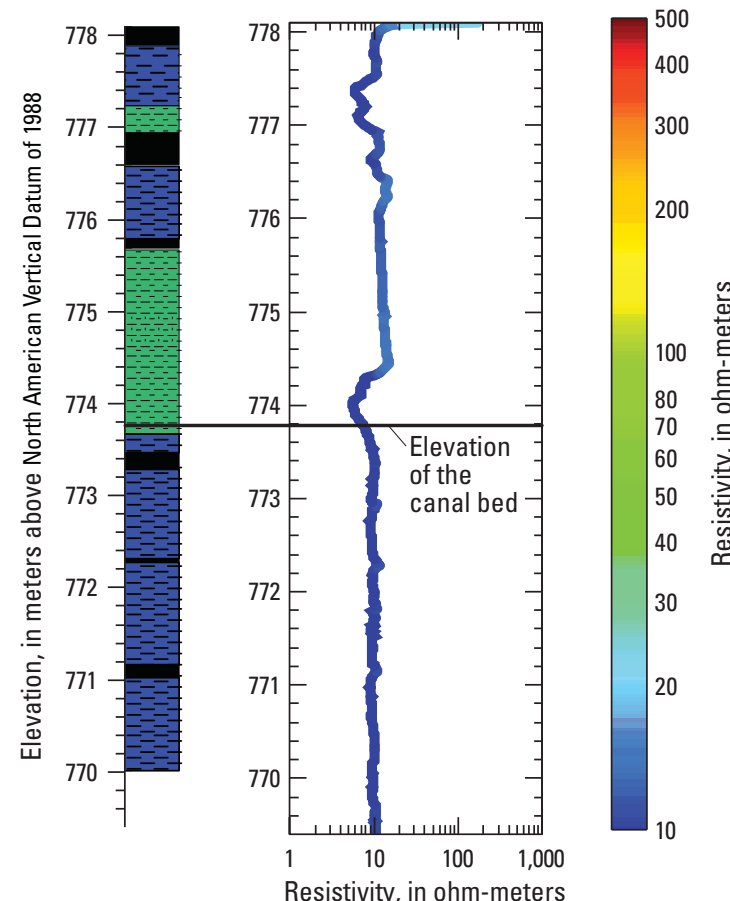

C

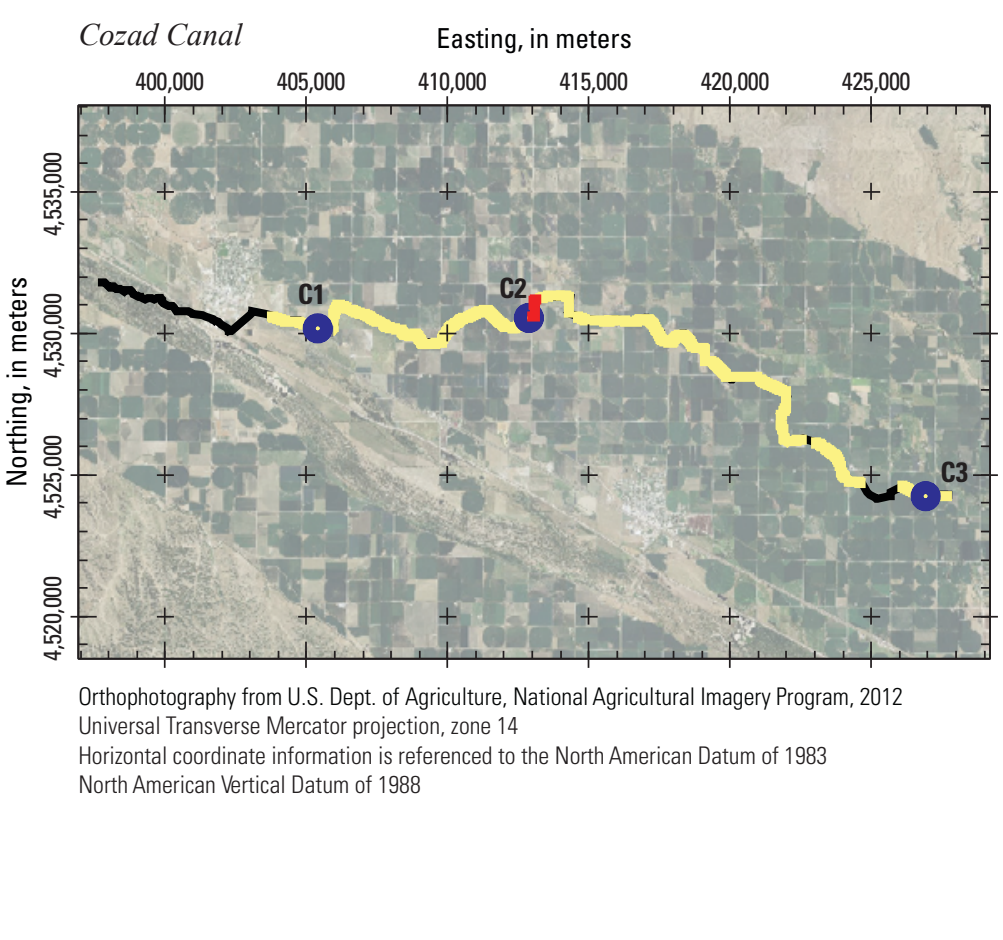

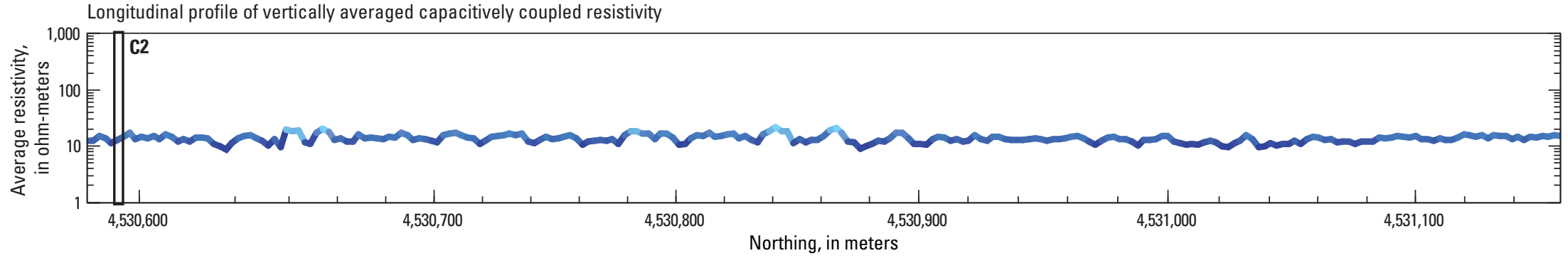

Figure 6. Comparison of capacitively coupled resistivity section and lithologic and electrical conductivity (EC) data from core C2. Survey results showing $(A)$ vertical profiles of lithologic and EC log data from core C2 collected on the canal bank near Cozad Canal; $(B)$ location of canal, surveyed reaches, and displayed results; and $(C)$ inverted capacitively coupled resistivity section and vertically averaged resistivity profile. 
A C3 Lithology and electrical conductivity-derived resistivity log
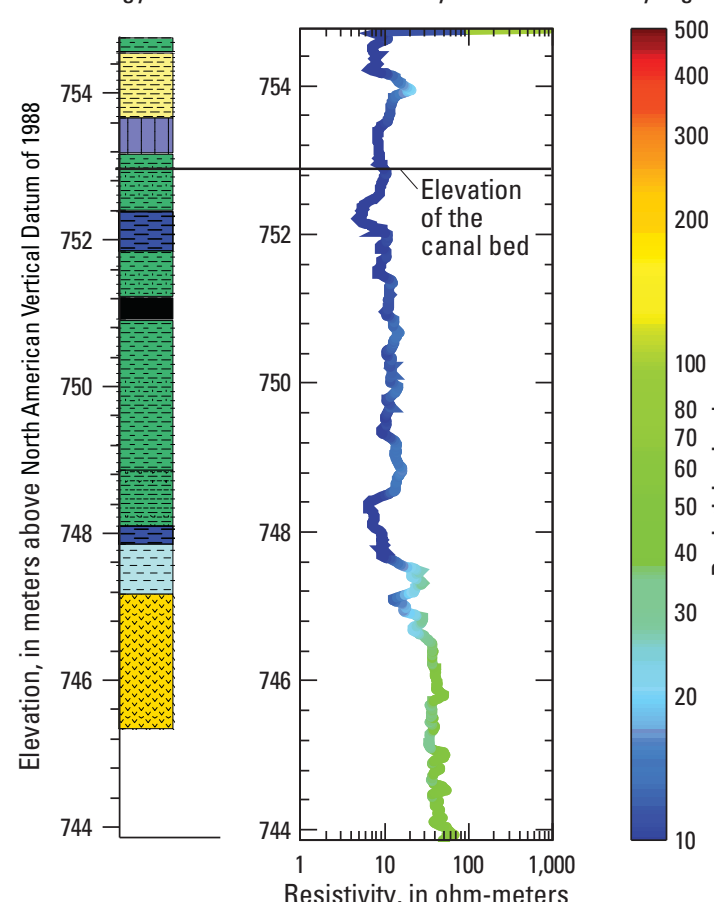

$\boldsymbol{B}$

\begin{tabular}{|c|c|c|}
\hline \multicolumn{3}{|c|}{ EXPLANATION } \\
\hline \multicolumn{3}{|c|}{ Lithology } \\
\hline & Label & Description \\
\hline & NS & No sample \\
\hline एाँ & $\mathrm{OH}$ & Organic clayey silt \\
\hline$E=$ & $\mathrm{CL}$ & Clay-silty clay \\
\hline-1 & CL-ML & Silty clay-clayey silt \\
\hline & ML & Sandy silt \\
\hline & ML-SM & Sandy silt-silty sand \\
\hline$E^{2}$ & & Silty sand \\
\hline 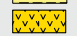 & & Sand, well sorted \\
\hline \multicolumn{3}{|c|}{ Canal location } \\
\hline & \multicolumn{2}{|c|}{ Surveyed section of canal } \\
\hline & \multicolumn{2}{|c|}{ Displayed section of canal } \\
\hline & \multicolumn{2}{|c|}{$\begin{array}{l}\text { Continuous sediment core and } \\
\text { electrical conductivity log } \\
\text { and identifier }\end{array}$} \\
\hline
\end{tabular}

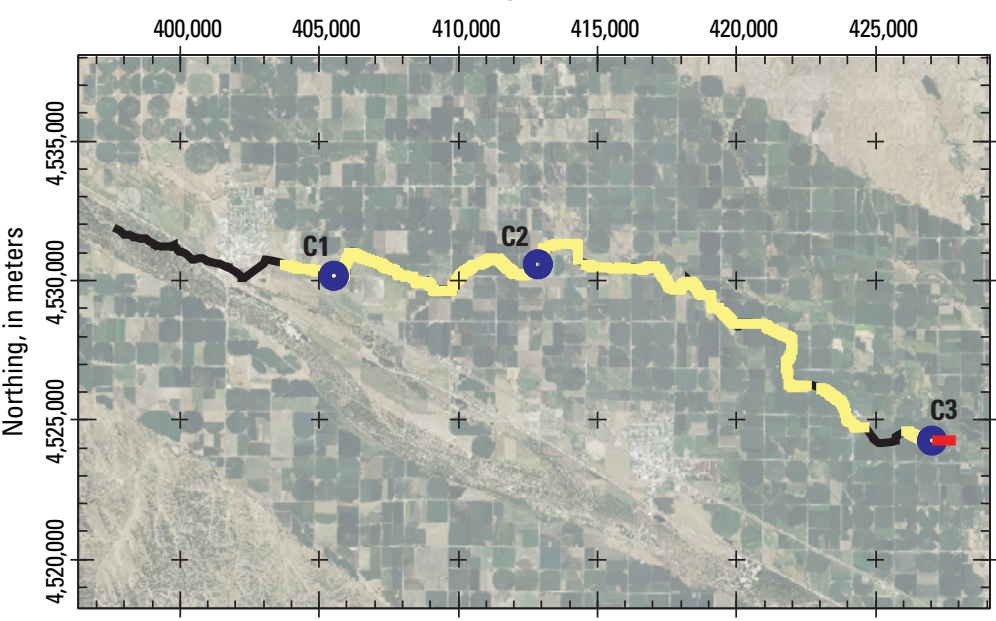

Orthophotography from U.S. Dept. of Agriculture, National Agricultural Imagery Program, 2012 Universal Transverse Mercator projection, zone 14

Horizontal coordinate information is referenced to the North American Datum of 1983

North American Vertical Datum of 1988

C

Inverted capacitively coupled resistivity section

Canal bed
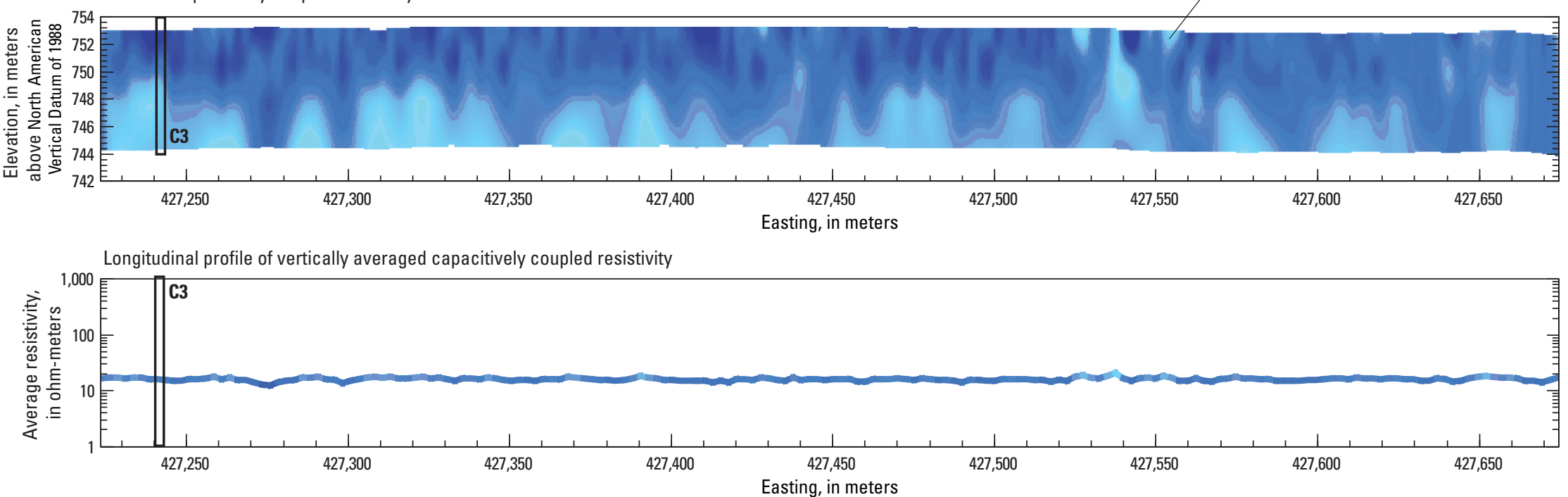

Figure 7. Comparison of capacitively coupled resistivity section and lithologic and electrical conductivity (EC) data from core C3. Survey results showing $(A)$ vertical profiles of lithologic and EC log data from core C3 collected on the canal bank near Cozad Canal; $(B)$ location of canal, surveyed reaches, and displayed results; and $(C)$ inverted capacitively coupled resistivity section and vertically averaged resistivity profile. 
A TM1 Lithology and electrical conductivity-derived resistivity log

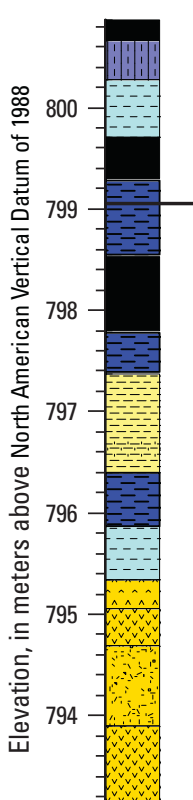

793

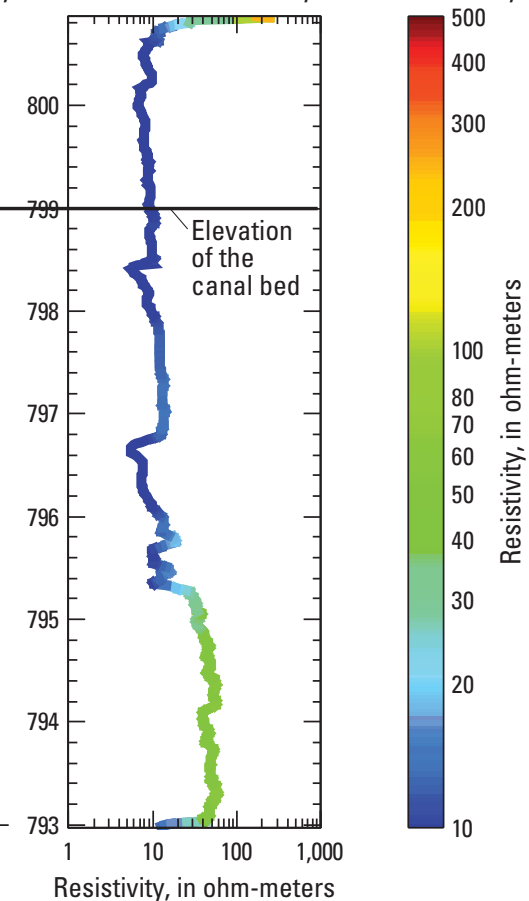

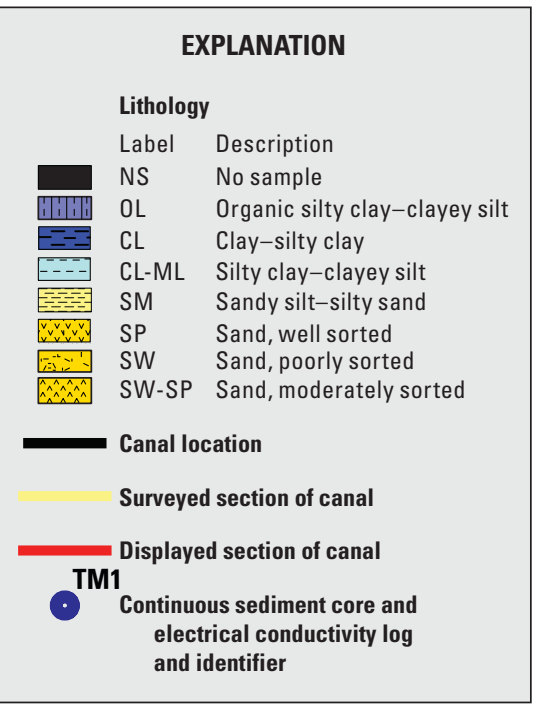

Thirty-Mile Canal Easting, in meters

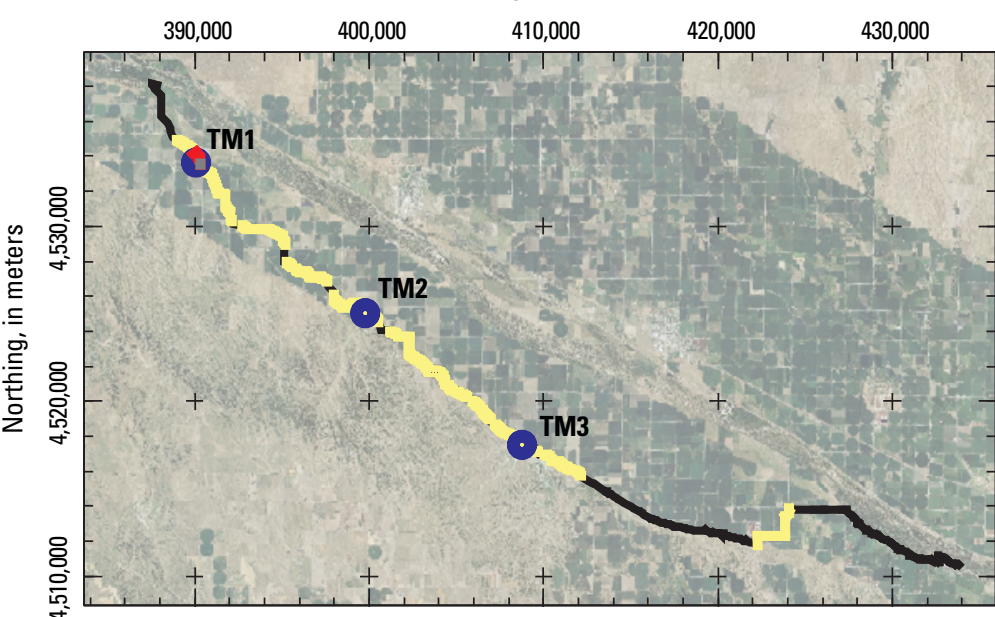

Orthophotography from U.S. Dept. of Agriculture, National Agricultural Imagery Program, 2012 Orthophotography from U.S. Dept. of Agriculture,
Universal Transverse Mercator projection, zone 14

Universal Transverse Mercator projection, zone 14 North American Vertical Datum of 1988

C

verted capacitively coupled resistivity section
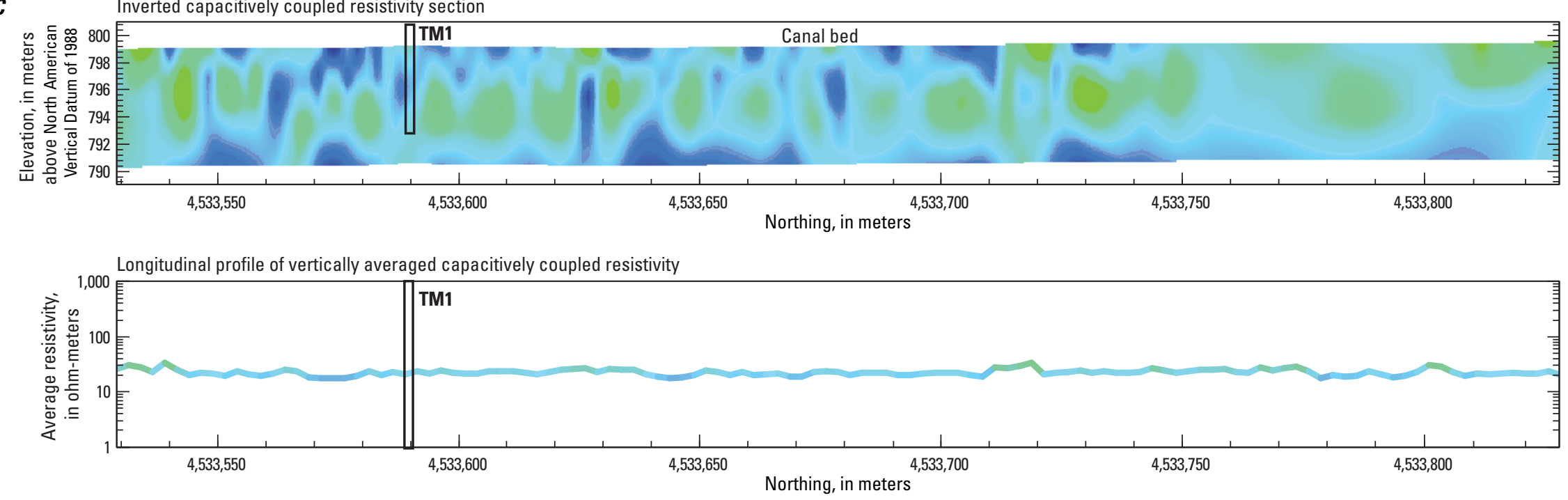

Figure 8. Comparison of capacitively coupled resistivity section and lithologic and electrical conductivity (EC) data from core TM1. Survey results showing ( $A$ ) vertical profiles of lithologic and EC log data from core TM1 collected on the canal bank near Thirty-Mile Canal; $(B)$ location of canal, surveyed reaches, and displayed results; and $(C)$ inverted capacitively coupled resistivity section and vertically averaged resistivity profile. 
A TM2 Lithology and electrical conductivity-derived resistivity log

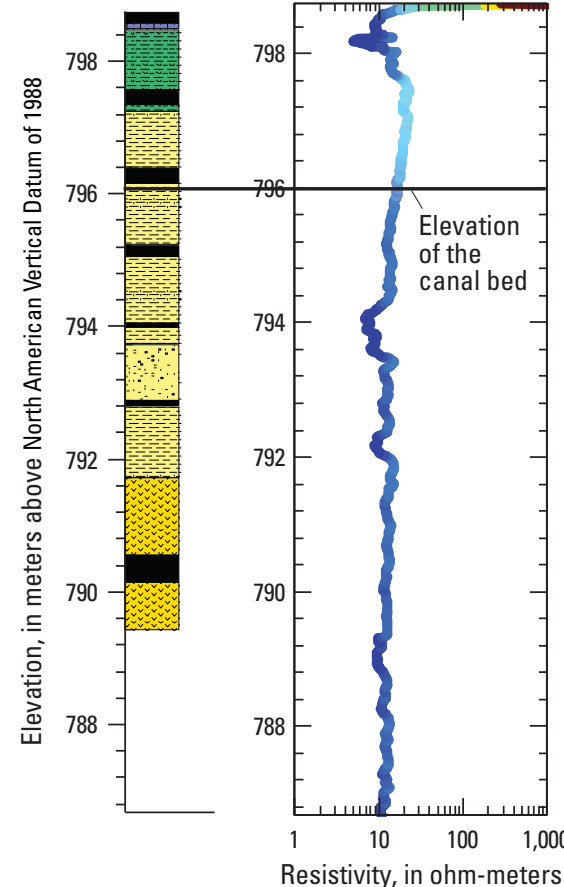

$\boldsymbol{B}$

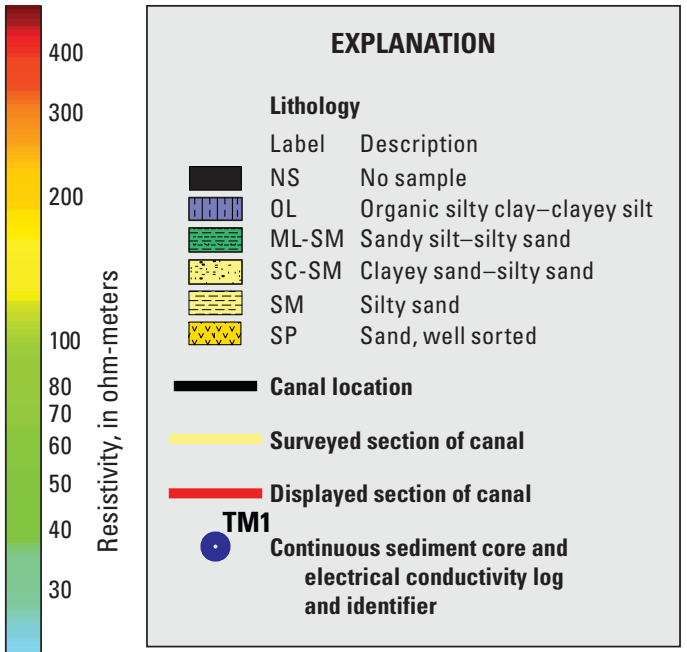

Thirty-Mile Canal Easting, in meters

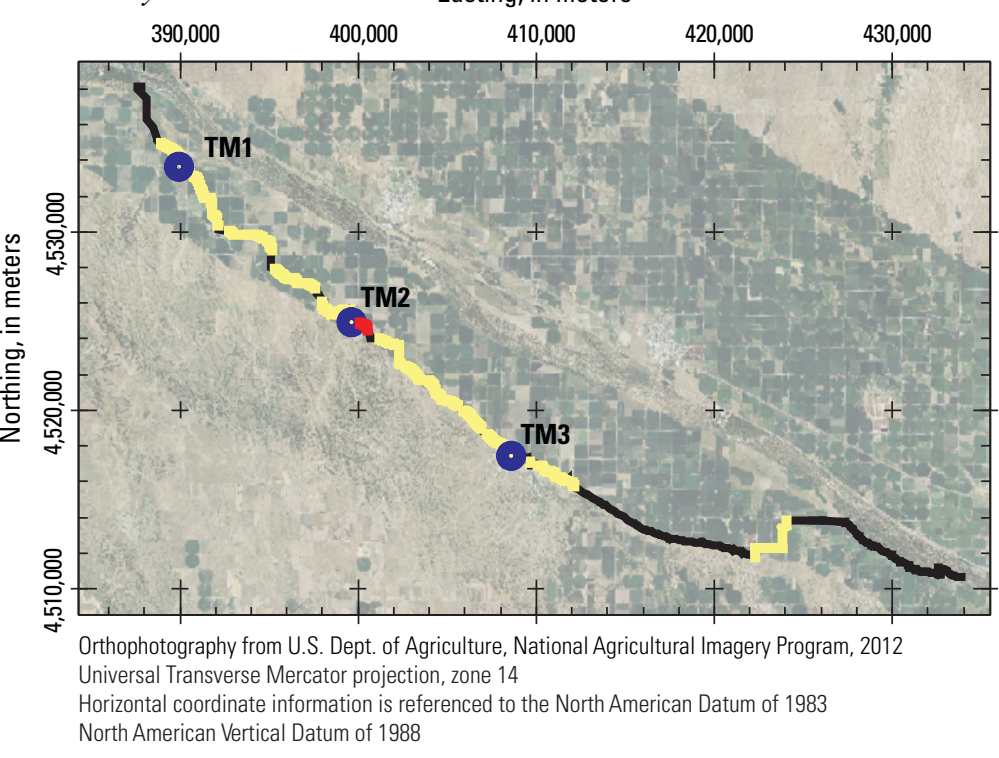

C Inverted capacitively coupled resistivity section
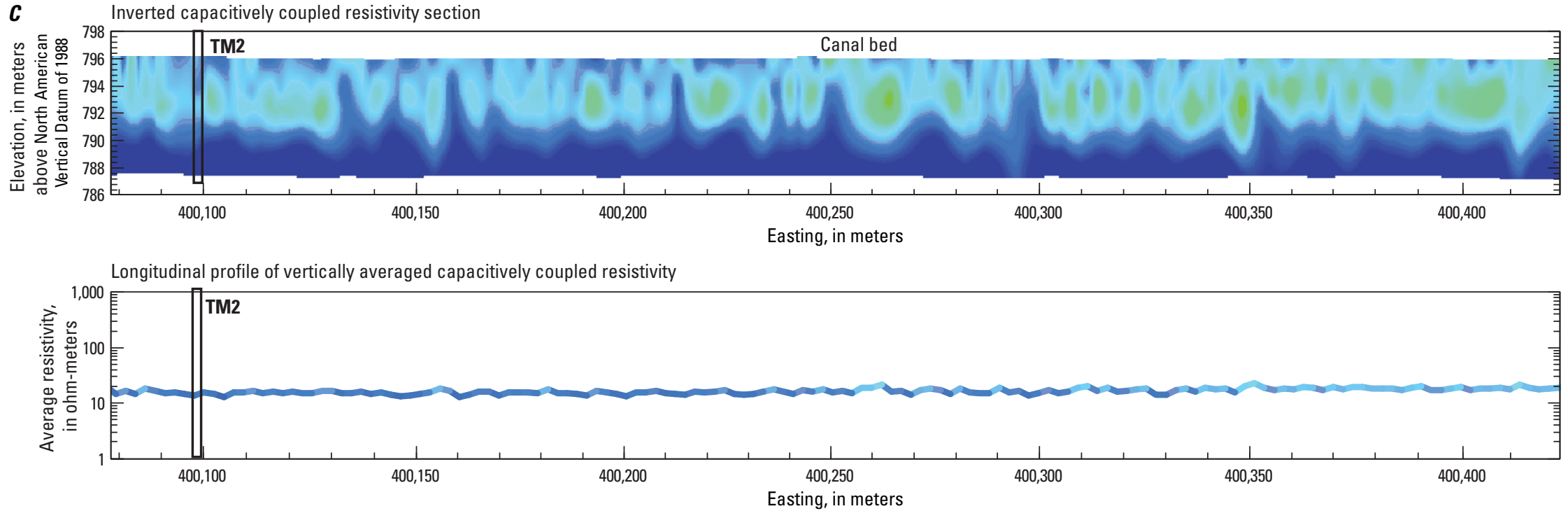

Figure 9. Comparison of capacitively coupled resistivity section and lithologic and electrical conductivity (EC) data from core TM2. Survey results showing ( $A$ ) vertical profiles of lithologic and EC log data from core TM2 collected on the canal bank near Thirty-Mile Canal; $(B)$ location of canal, surveyed reaches, and displayed results; and $(C)$ inverted capacitively coupled resistivity section and vertically averaged resistivity profile. 
A TM3 Lithology and electrical conductivity-derived resistivity log

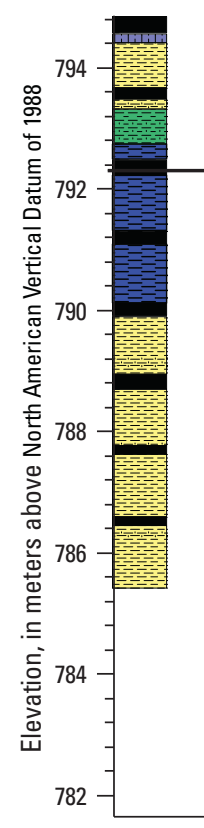

$\boldsymbol{B}$

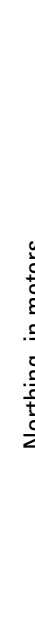

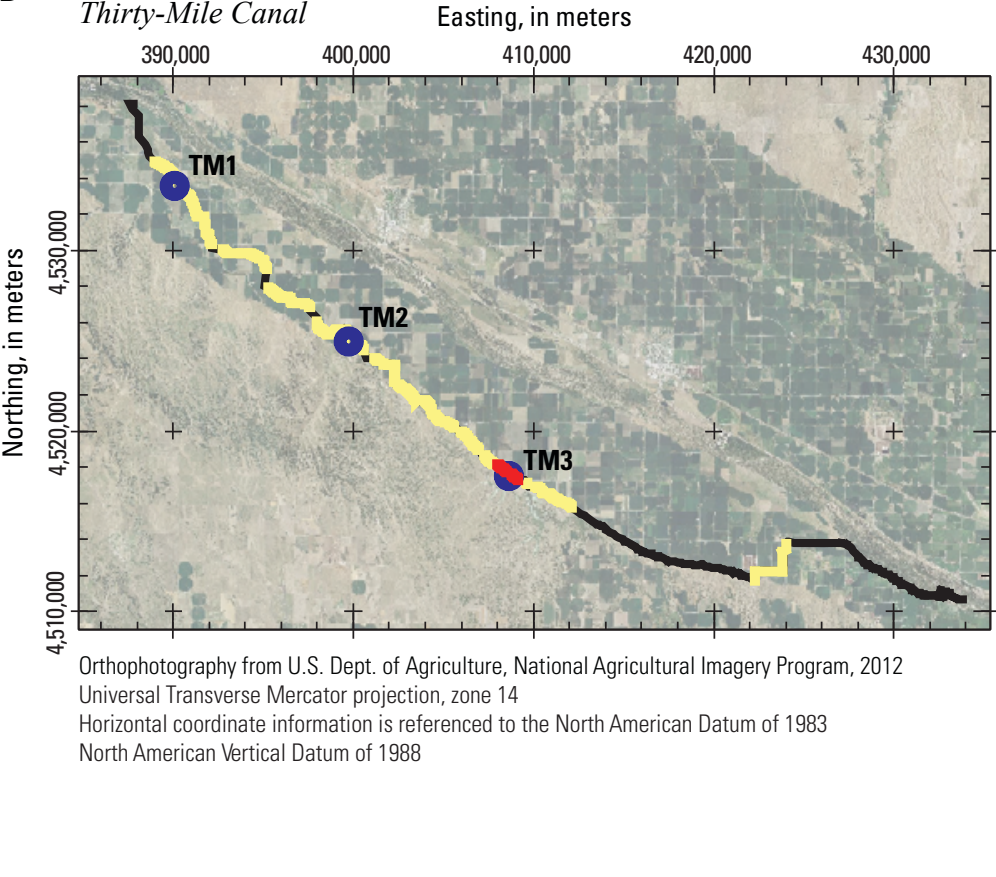
$\begin{array}{cccc}1 & 10 & 100 & 1,000\end{array}$

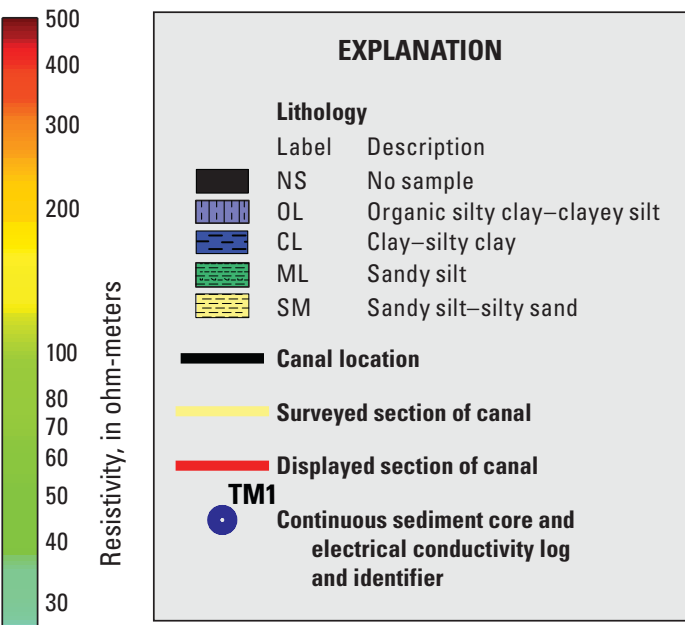

20

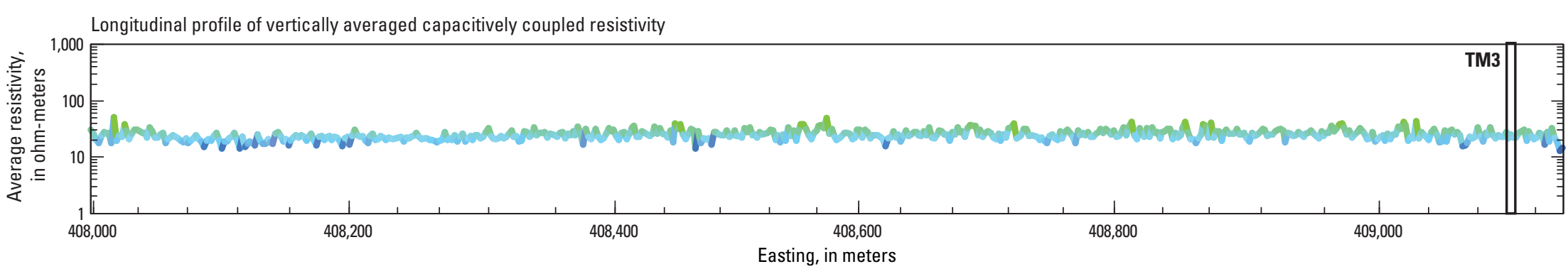

Figure 10. Comparison of capacitively coupled resistivity section and lithologic and electrical conductivity (EC) data from core TM3. Survey results showing $(A)$ vertical profiles of lithologic and EC log data from core TM3 collected on the canal bank near Thirty-Mile Canal; $(B)$ location of canal, surveyed reaches, and displayed results; and $(C)$ inverted capacitively coupled resistivity section and vertically averaged resistivity profile. 
A OA1 Lithology and electrical conductivity-derived resistivity log
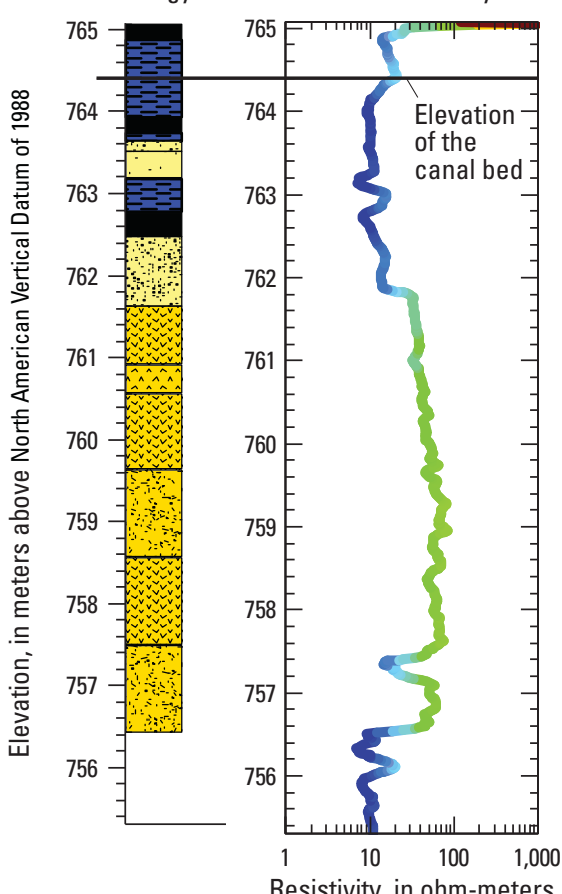
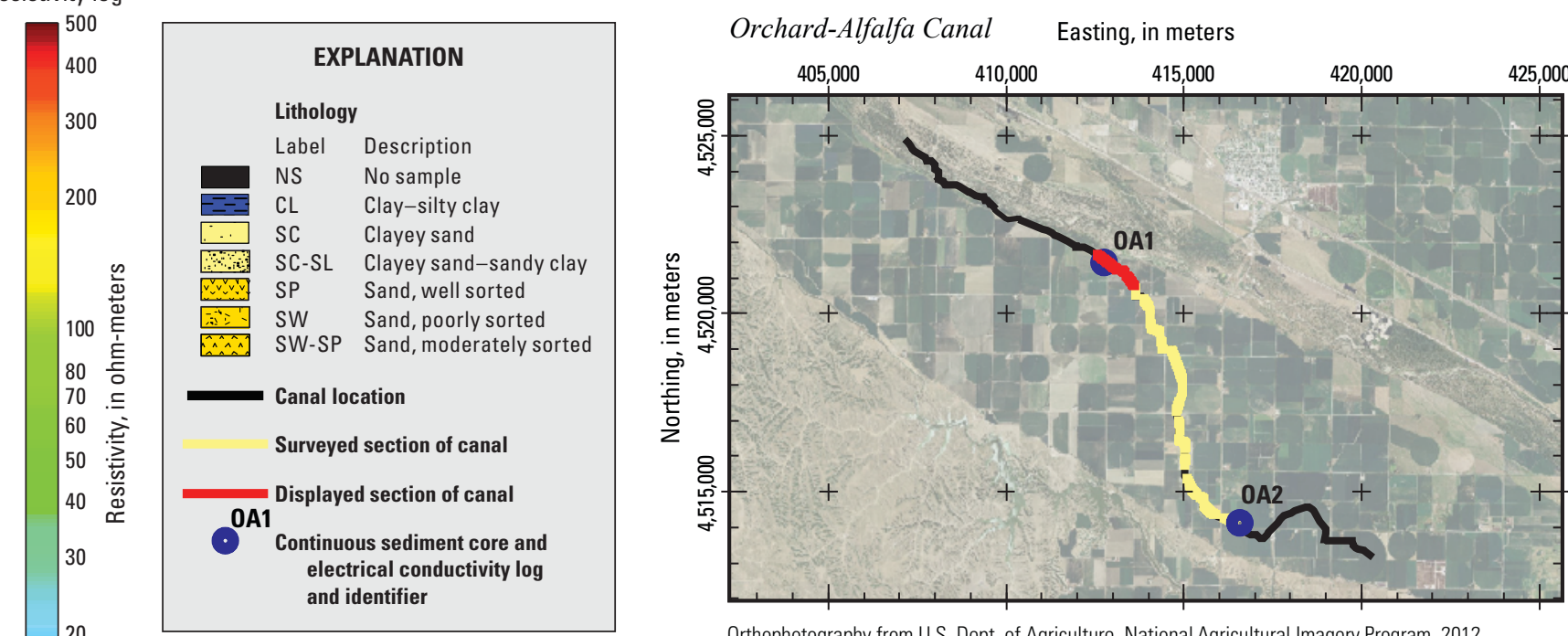

Orthophotography from U.S. Dept. of Agriculture, National Agricultural Imagery Program, 2012 Universal Transverse Mercator projection, zone 14

Horizontal coordinate information is referenced to the North American Datum of 1983 North American Vertical Datum of 1988

C Inverted capacitively coupled resistivity section

0A1
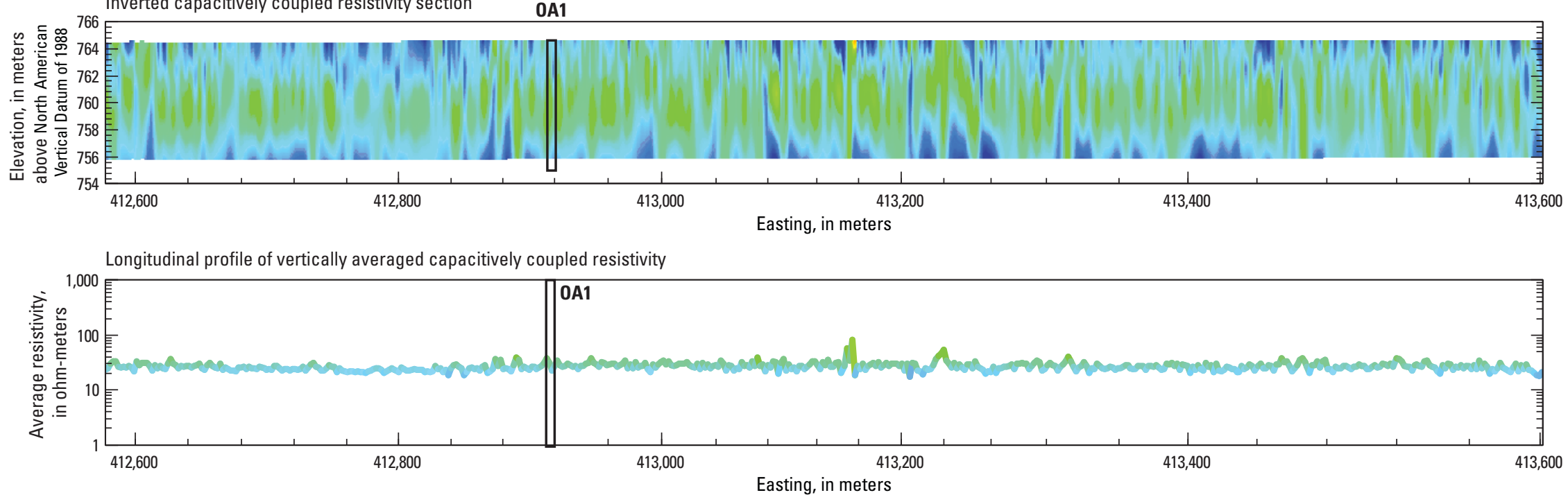

Figure 11. Comparison of capacitively coupled resistivity section and lithologic and electrical conductivity (EC) data from core $0 A 1$. Survey results showing $(A)$ vertical profiles of lithologic and EC log data from core OA1 collected on the canal bank near Orchard-Alfalfa Canal; $(B)$ location of canal, surveyed reaches, and displayed results; and $(C)$ inverted capacitively coupled resistivity section and vertically averaged resistivity profile. 
A OA2 Lithology and electrical conductivity-derived resistivity log

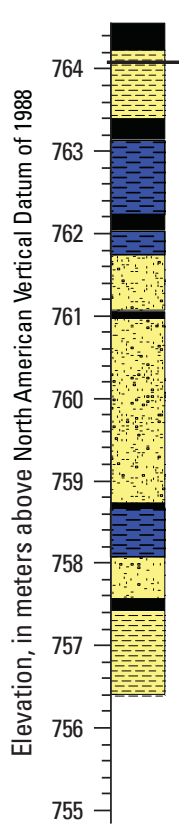

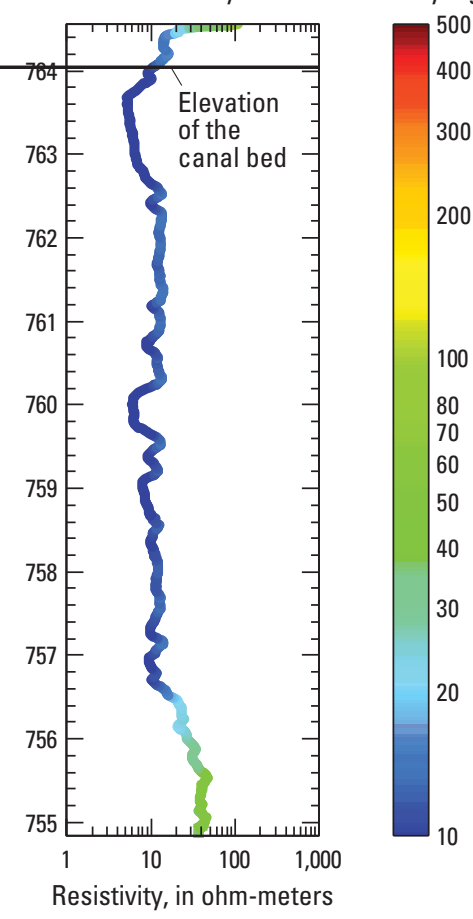

B

\begin{tabular}{|l|l|}
\multicolumn{2}{|c|}{ EXPLANATION } \\
Lithology \\
Label $\quad$ Description \\
NS $\quad$ No sample \\
CL $\quad$ Clay-silty clay \\
SC-SM & Clayey sand-silty clay \\
SC-CL & Clayey sand-sandy clay \\
SM $\quad$ Sandy silt-silty sand \\
Canal location \\
Surveyed section of canal \\
Displayed section of canal \\
Continuous sediment core and \\
electrical conductivity log \\
and identifier
\end{tabular}

Orchard-Alfalfa Canal Easting, in meters

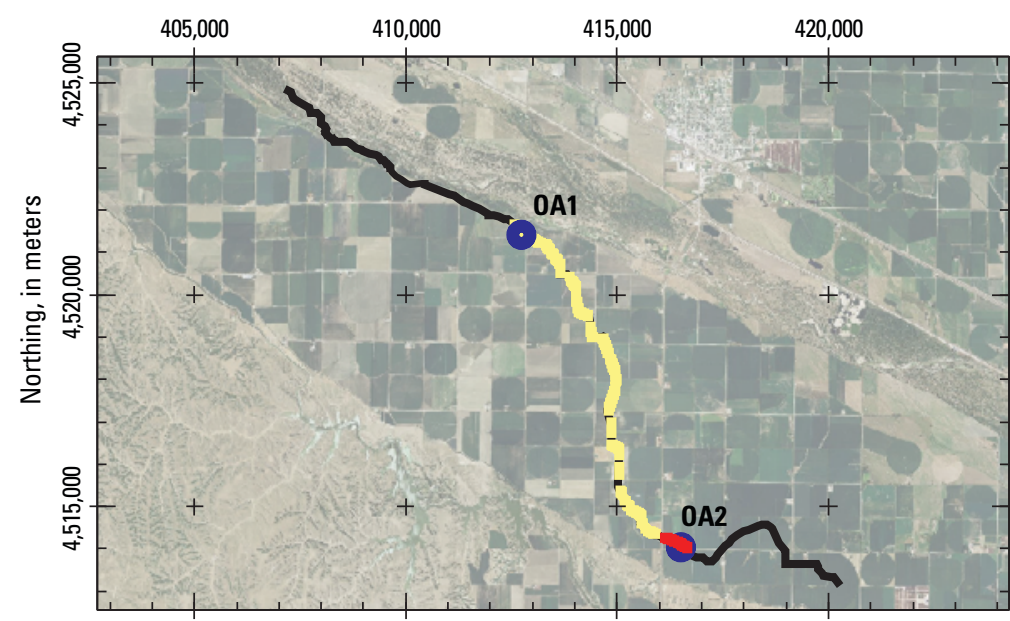

Orthophotography from U.S. Dept. of Agriculture, National Agricultural Imagery Program, 2012 Universal Transverse Mercator projection, zone 14

Horizontal coordinate information is referenced to the North American Datum of 1983 North American Vertical Datum of 1988

C Inverted capacitively coupled resistivity section
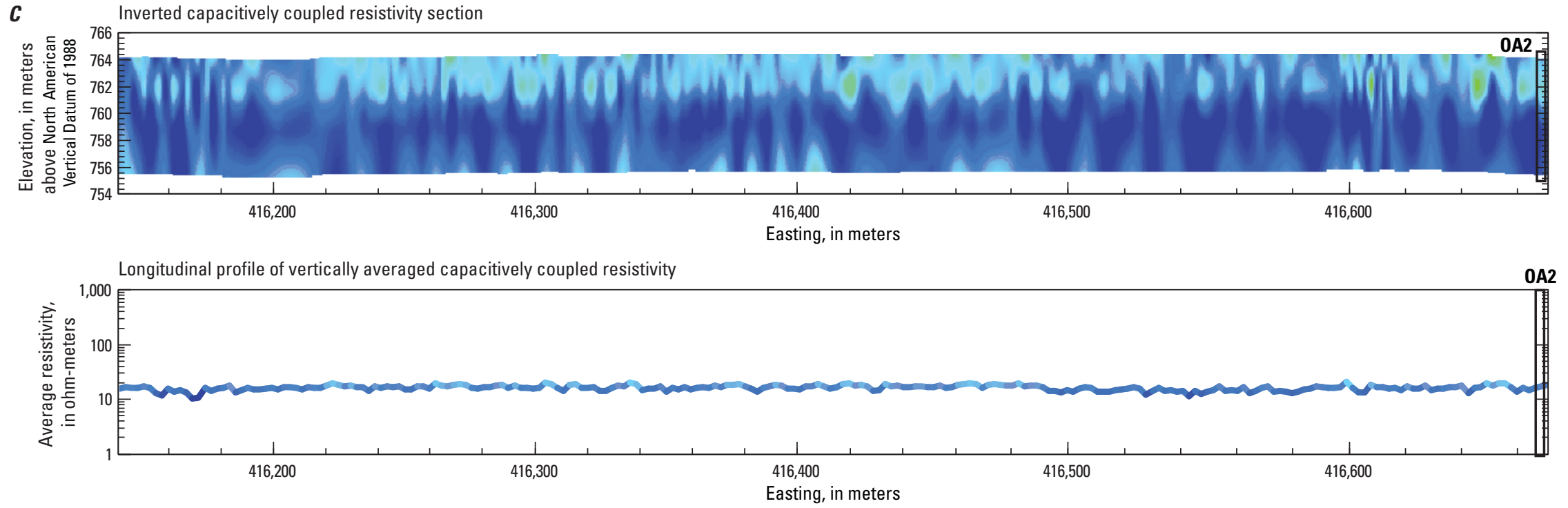

Figure 12. Comparison of capacitively coupled resistivity section and lithologic and electrical conductivity (EC) data from core $0 A 2$. Survey results showing $(A)$ vertical profiles of lithologic and EC log data from core OA2 collected on the canal bank near Orchard-Alfalfa Canal; $(B)$ location of canal, surveyed reaches, and displayed results; and ( $C$ ) inverted capacitively coupled resistivity section and vertically averaged resistivity profile. 
A K2 (Buckle) Lithology and electrical conductivity-derived resistivity log

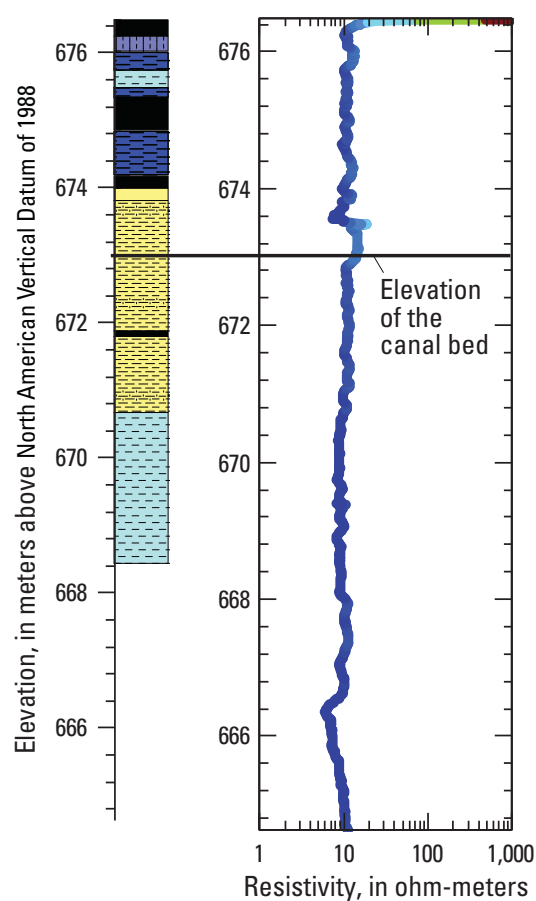

$\boldsymbol{B}$

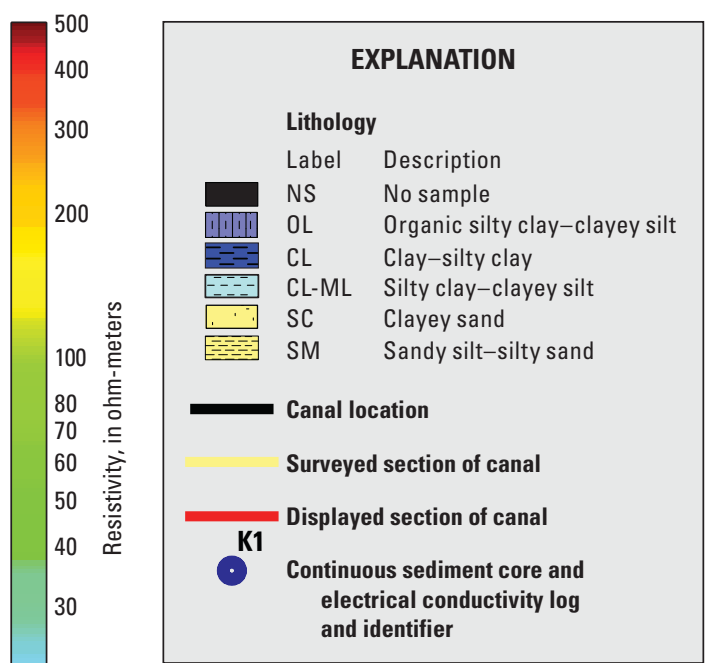

Kearney Canal Easting, in meters

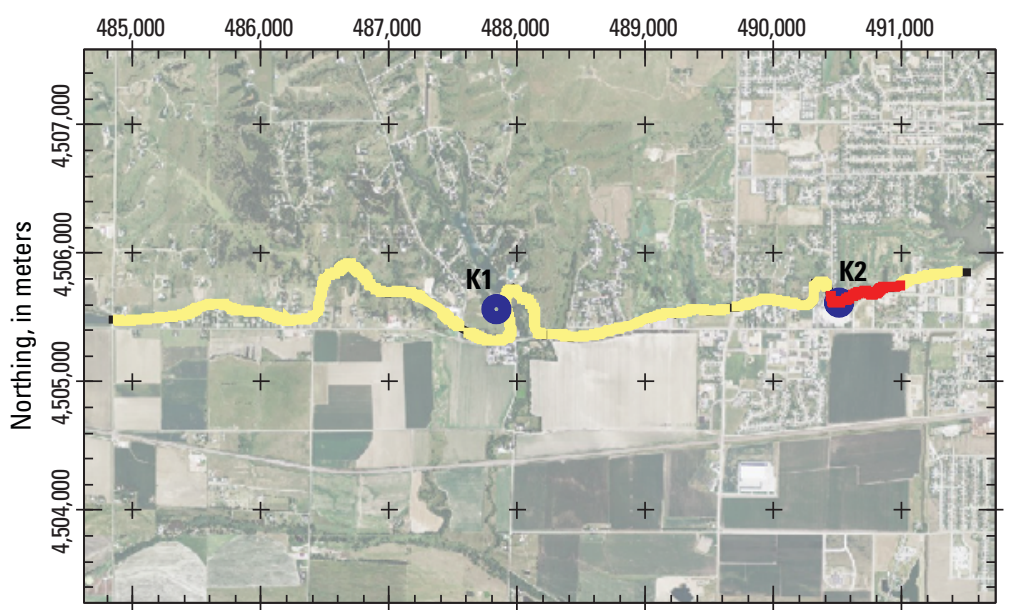

Orthophotography from U.S. Dept. of Agriculture, National Agricultural Imagery Program, 2012 Universal Transverse Mercator projection, zone 14

Horizontal coordinate information is referenced to the North American Datum of 1983 North American Vertical Datum of 1988

$c$

Inverted capacitively coupled resistivity section
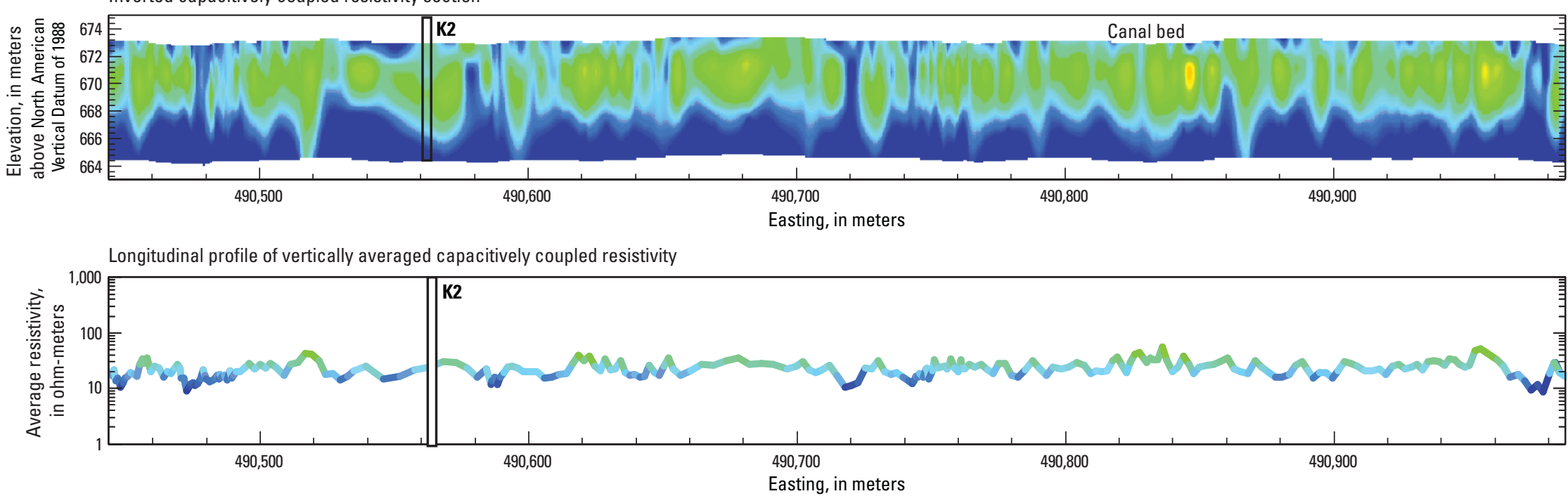

Figure 13. Comparison of capacitively coupled resistivity section and lithologic and electrical conductivity (EC) data from core K2 (Buckle). Survey results showing $(A)$ vertica profiles of lithologic and EC log data from core K2 (Buckle) collected on the canal bank near Kearney Canal; $(B)$ location of canal, surveyed reaches, and displayed results; and $(C)$ inverted capacitively coupled resistivity section and vertically averaged resistivity profile. 
A K1 Lithology and electrical conductivity-derived resistivity log

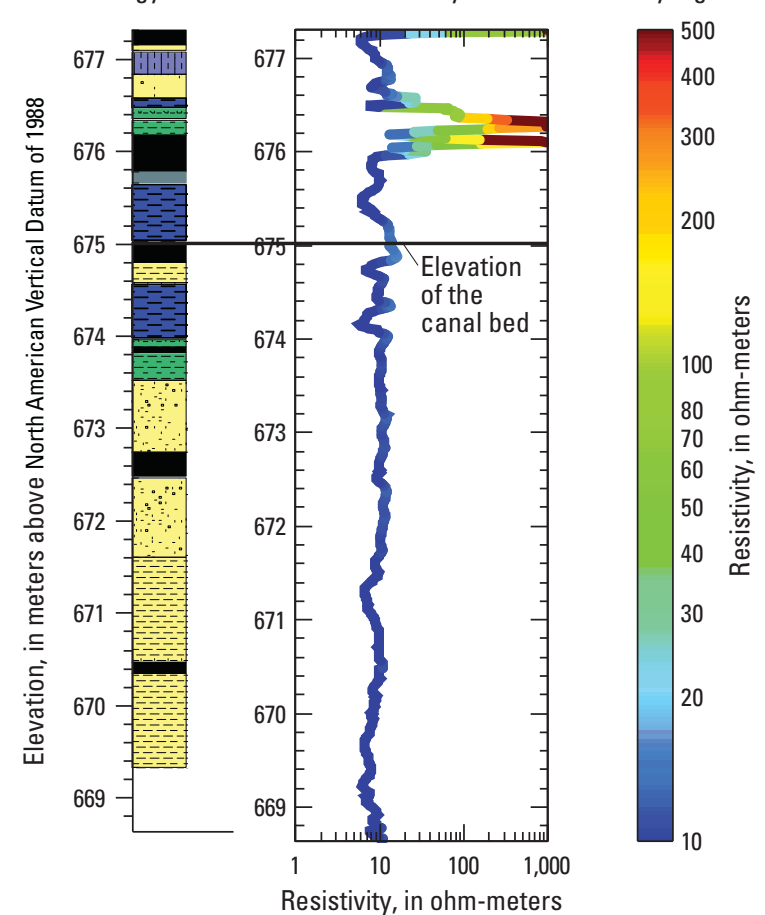

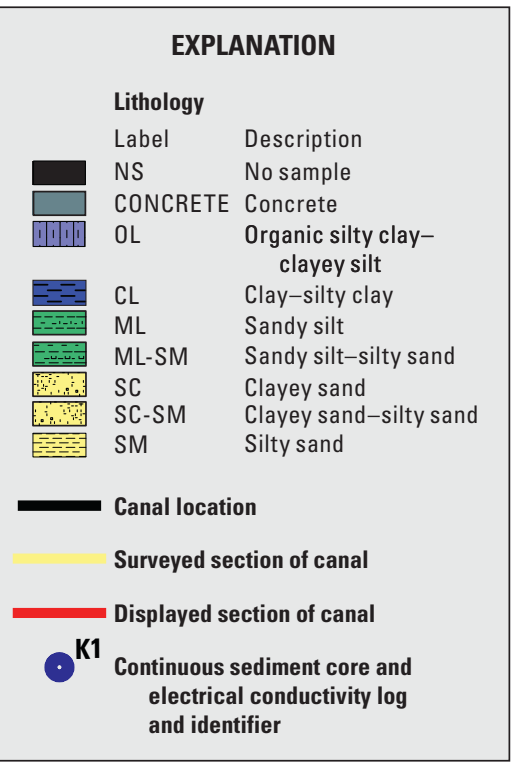

Kearney Canal Easting, in meters

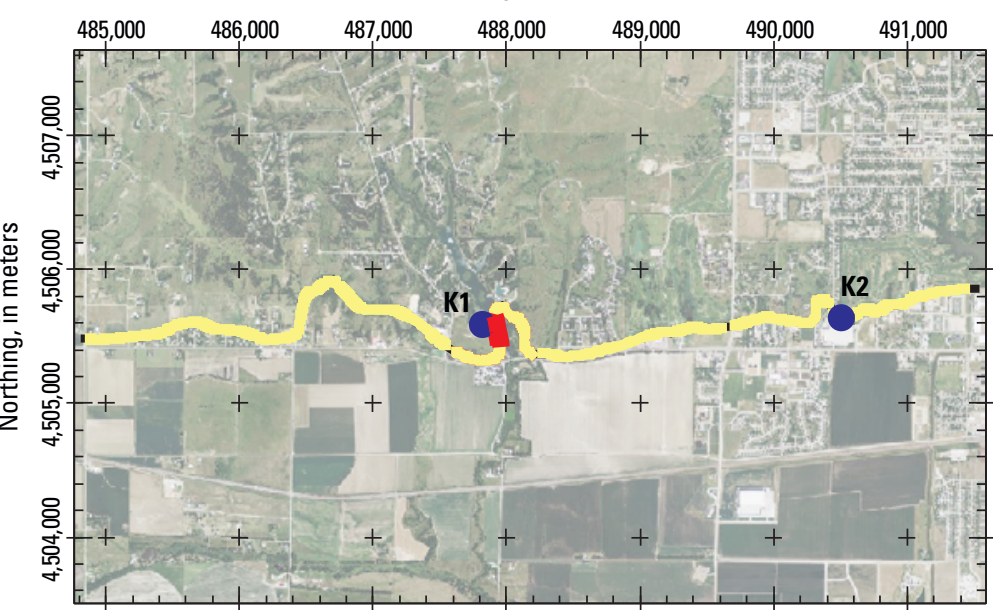

Orthophotography from U.S. Dept. of Agriculture, National Agricultural Imagery Program, 2012 Universal Transverse Mercator projection, zone 14

Horizontal coordinate information is referenced to the North American Datum of 1983 North American Vertical Datum of 1988

C Inverted capacitively coupled resistivity section
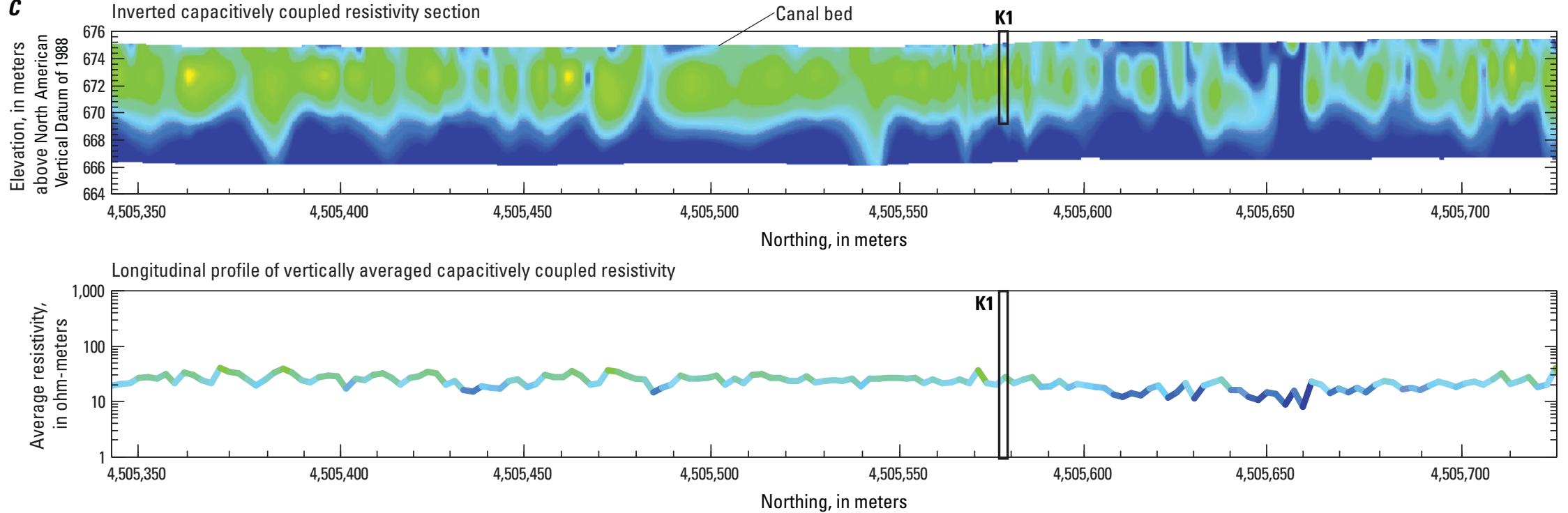

Figure 14. Comparison of capacitively coupled resistivity section and lithologic and electrical conductivity (EC) data from core K1. Survey results showing $(A)$ vertical profiles of lithologic and EC log data from core K1 collected on the canal bank near Kearney Canal; $(B)$ location of canal, surveyed reaches, and displayed results; and $(C)$ inverted capacitively coupled resistivity section and vertically averaged resistivity profile. 
A G4 Lithology and electrical conductivity-derived resistivity log

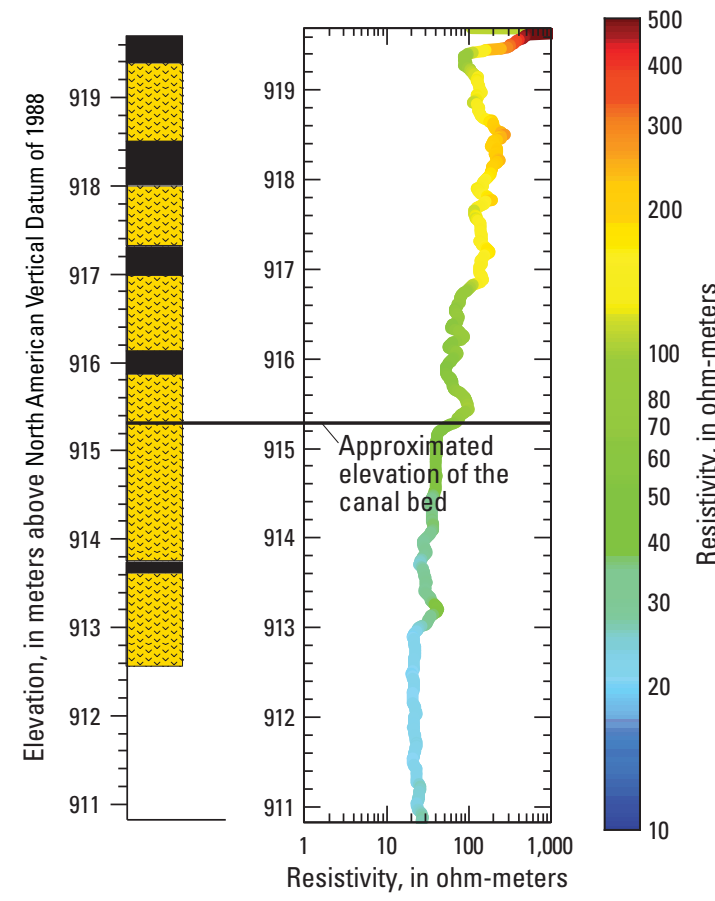

C

Inverted capacitively coupled resistivity section
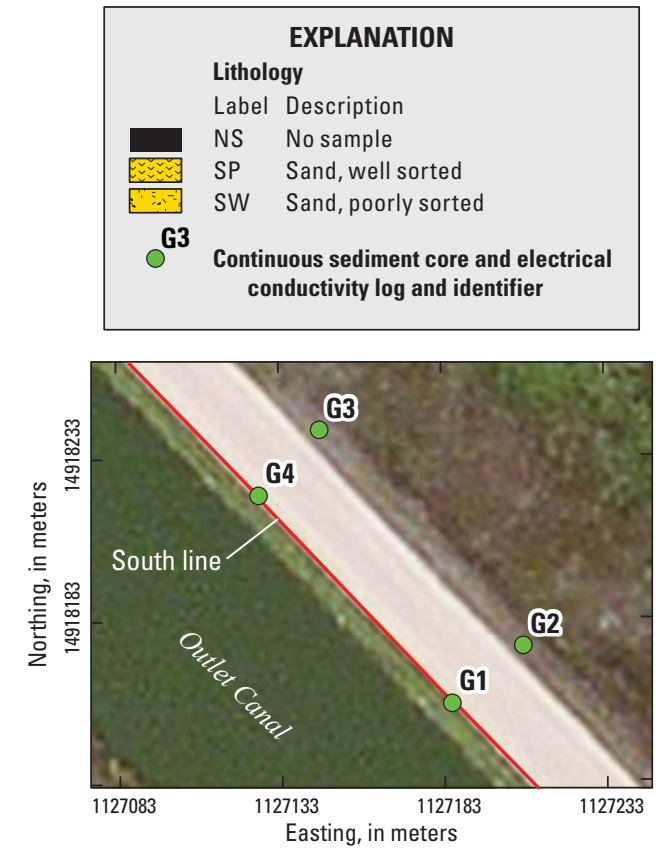

Orthophotography from Esi wolding Orthophotography from Esri World Imagery, 2011 Horizontal coordinate information is referenced to the North American Datum of 1983 North Amercian Vertical Datum of 198
B G1 Lithology and electrical conductivity-derived resistivity log

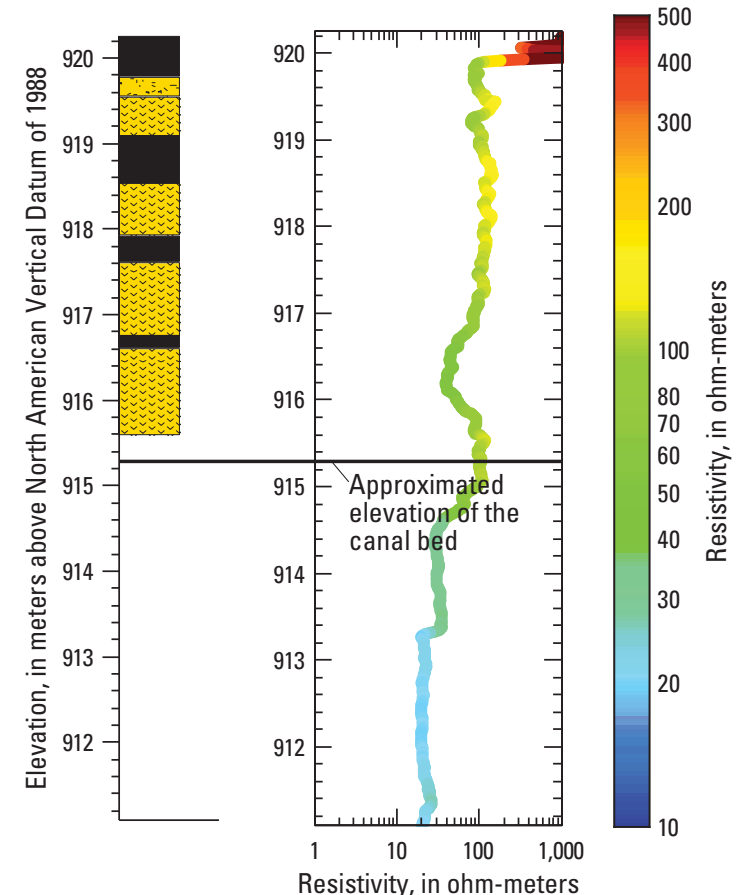

G4 G1

Figure 15. Comparison of capacitively coupled resistivity section and lithologic and electrical conductivity (EC) data from cores G4 and G1. Survey results showing vertica profiles of lithologic and EC log data from $(A)$ core $\mathrm{G} 4$ and $(B)$ core $\mathrm{G} 1$ collected on the south line along the north access road of Outlet Canal; and $(C)$ inverted capacitively coupled resistivity section and vertically averaged resistivity profile. 
A G3 Lithology and electrical conductivity-derived resistivity log

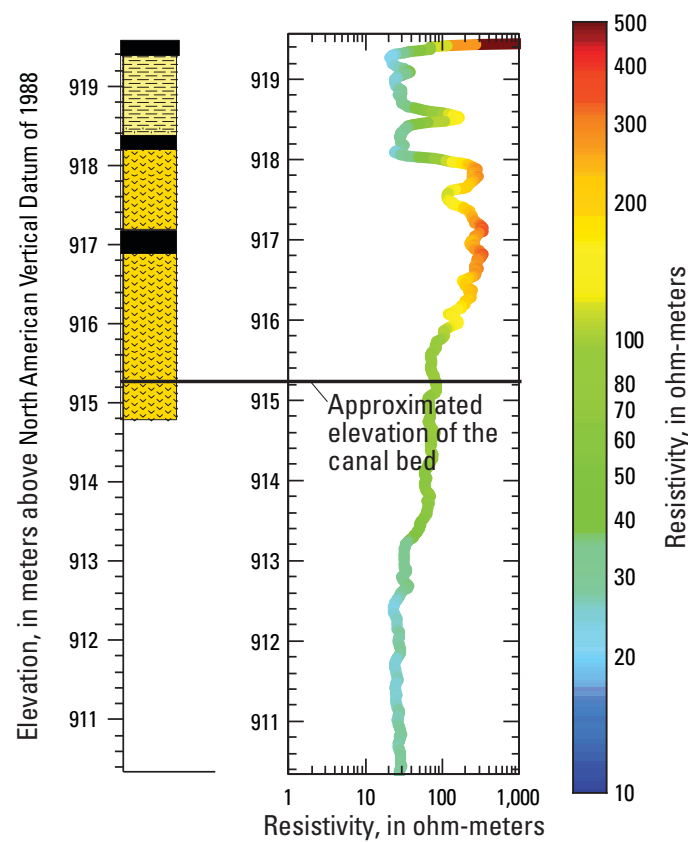

C

Inverted capacitively coupled resistivity section
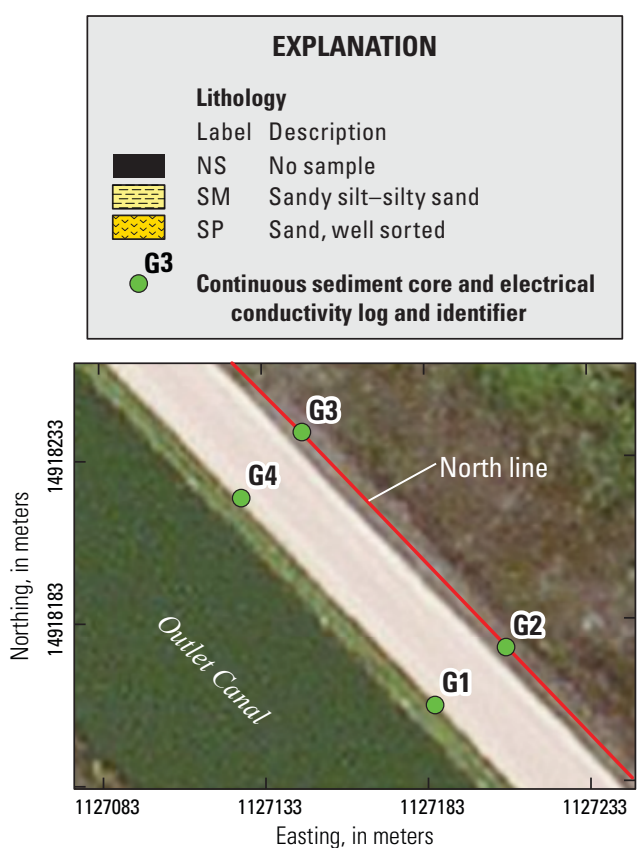

Orthophotography from Esri World Imagery, 2011

Univeral Transverse Mercator projection, zone 14

Horizontal coordinate information is referenced to

Worth Amercinn Vertion
B G2 Lithology and electrical conductivity-derived resistivity log
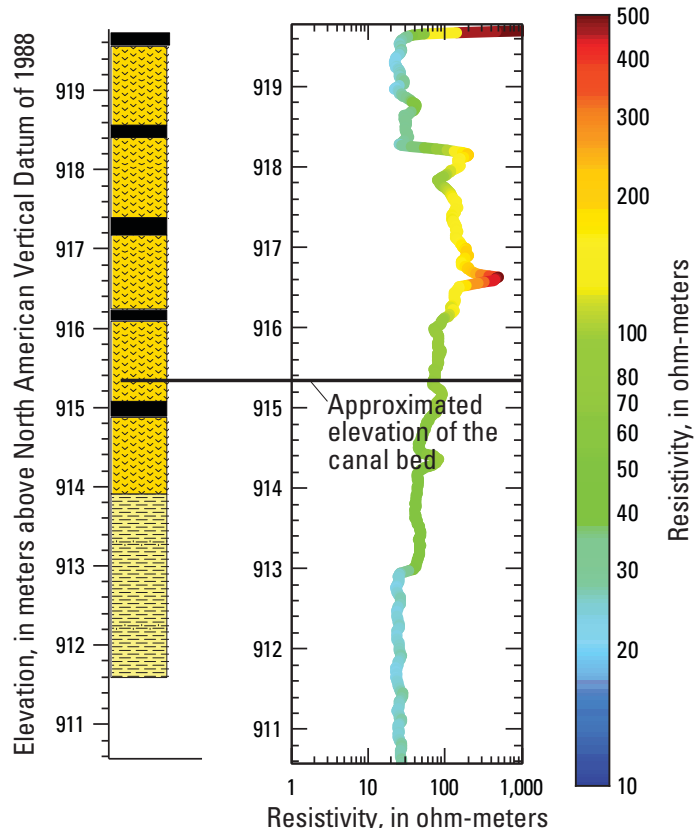

Figure 16. Comparison of capacitively coupled resistivity section and lithologic and electrical conductivity (EC) data from cores G3 and G2. Survey results showing vertical profiles of lithologic and EC log data from $(A)$ core $\mathrm{G} 3$ and $(B)$ core $\mathrm{G} 2$ collected on the north line along the north access road of Outlet Canal; and $(C)$ inverted capacitively coupled resistivity section and vertically averaged resistivity profile. 


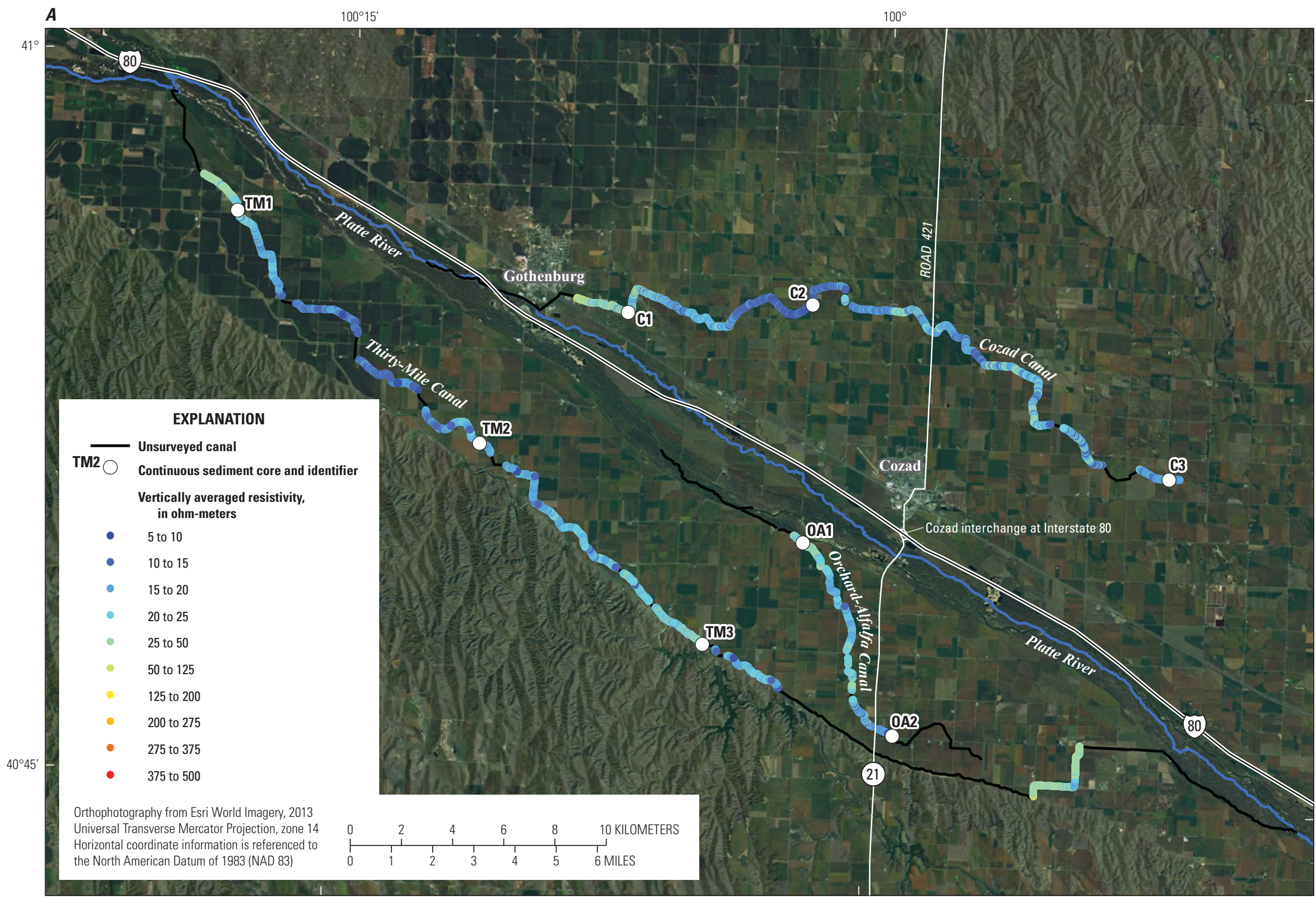

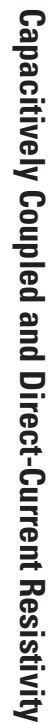

Figure 17. Vertically averaged resistivity and location of sediment cores for $(A)$ Cozad, Thirty-Mile, and Orchard-Alfalfa Canals, and $(B)$ Kearney Canal. 


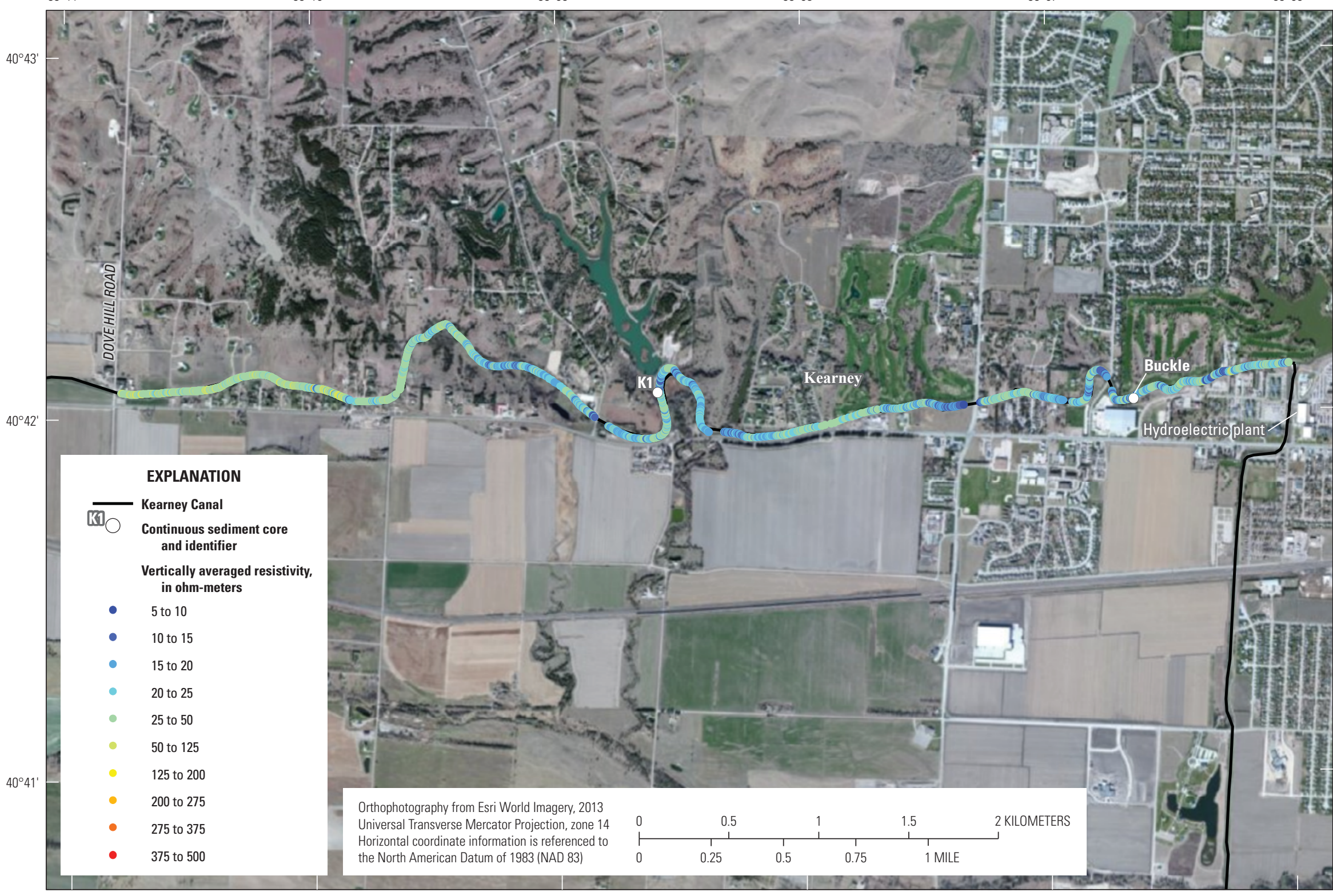


Table 2. Detailed lithologic descriptions from continuous sediment cores.

[Munsell color classification codes are explained in Munsell Color (1992). For example, 2.5Y 4/2 gives the hue, value, and chroma of each color; where 2.5Y is the hue, 4 is the value, and 2 is the chroma. Elevation in meters above North American Vertical Datum of 1988 (NAVD 88); horizontal coordinate information referenced to Universal Transverse Mercator projection zone 14; m, meter; E., easting; N., northing; --, no data; \%, percent; cm, centimeter]

\begin{tabular}{|c|c|c|}
\hline $\begin{array}{l}\text { Depth below land } \\
\text { surface (in meters) }\end{array}$ & Lithology & Munsell color \\
\hline \multicolumn{3}{|c|}{ Continuous sediment core C1; 405,783 m E.; 4,530,094 m N.; $779.94 \mathrm{~m}$ above NAVD 88} \\
\hline $0-0.22$ & No sample & -- \\
\hline $0.22-0.63$ & Sandy silt,very fine, soft, roots, small calcareous nodules, slightly calcareous & $2.5 \mathrm{Y} 4 / 2$ \\
\hline $0.63-1.16$ & Sandy silt, very fine, soft, small roots, slightly to moderately calcareous & $2.5 \mathrm{Y} 3 / 3$ \\
\hline $1.16-1.31$ & No sample & -- \\
\hline $1.31-1.88$ & Silt,very fine, soft, slightly calcareous & $2.5 \mathrm{Y} 4 / 2$ \\
\hline $1.88-2.18$ & Silt,very fine, sticky, calcareous nodules, darker than above & $2.5 \mathrm{Y} 3 / 2$ \\
\hline $2.18-2.32$ & Silty clay, soft, with organic matter, very dark in areas, slightly calcareous & $2.5 Y 2.5 / 1$ \\
\hline $2.32-2.51$ & No sample & -- \\
\hline $2.51-3.48$ & Silty clay, soft, slightly calcareous & $2.5 \mathrm{Y} 5 / 3$ \\
\hline $3.48-3.59$ & No sample & -- \\
\hline $3.59-3.97$ & Clayey silt, very fine, soft, slightly calcareous & $2.5 \mathrm{Y} 5 / 3$ \\
\hline $3.97-4.31$ & Clayey silt, minor silt content, soft & $2.5 \mathrm{Y} 4 / 2$ \\
\hline $4.31-4.64$ & $\begin{array}{l}\text { Sand, medium, moderately to well sorted, well rounded to subrounded, coarse towards the bot- } \\
\text { tom, with occasional fine to medium gravel (subrounded), } 80 \% \text { quartz, } 15 \% \text { feldspar, } 5 \% \text { maf- } \\
\text { ics }\end{array}$ & $2.5 \mathrm{Y} 5 / 4$ \\
\hline $4.64-4.93$ & No sample & -- \\
\hline $4.93-5.80$ & $\begin{array}{l}\text { Sand, medium to coarse, poorly sorted, rounded to subrounded, interbedded medium to coarse } \\
\text { gravel (subrounded), } 75 \% \text { quartz, } 15-20 \% \text { feldspar, } 5 \% \text { mafics }\end{array}$ & $2.5 Y 5 / 4-5 / 3$ \\
\hline $5.80-5.92$ & No sample & -- \\
\hline $5.92-6.96$ & $\begin{array}{l}\text { Sand, medium to coarse, poorly sorted, subrounded to rounded, pebble at bottom (about } 5 \mathrm{~cm} \text {, } \\
\text { subangular), } 75 \% \text { quartz, } 20 \% \text { feldspar, } 5 \% \text { mafics }\end{array}$ & $2.5 \mathrm{Y} 6 / 3$ \\
\hline \multicolumn{3}{|c|}{ Continuous sediment core C2; 413,022 m E.; 4,530,594 m N.; 778.09 m above NAVD 88} \\
\hline $0-0.21$ & No sample & -- \\
\hline $0.21-0.64$ & Clayey silt, stiff, very fine, organics, dark, roots, slightly calcareous & $2.5 \mathrm{Y} 3 / 1$ \\
\hline $0.64-1.16$ & Silt, soft, very fine, slight clay content, small amounts of organics varying in color $(2.5 \mathrm{Y} 3 / 1)$ & $2.5 \mathrm{Y} 5 / 3$ \\
\hline $1.16-1.51$ & No sample & -- \\
\hline $1.51-2.32$ & Clay, minor silt, very fine, soft, sticky, saturated at 1.81 , very pliable & $2.5 \mathrm{Y} 4 / 3$ \\
\hline $2.32-2.42$ & No sample & -- \\
\hline $2.42-3.48$ & Silt, very fine, soft, saturated, slightly calcareous & $2.5 \mathrm{Y} 5 / 3$ \\
\hline $3.48-4.16$ & Silt, very fine, soft, saturated, slightly calcareous & $2.5 \mathrm{Y} 4 / 4$ \\
\hline $4.16-4.44$ & Clayey silt, fine, with minor mudstone fragments, soft to stiff, very pliable, sticky & $2.5 \mathrm{Y} 4 / 2-3 / 2$ \\
\hline $4.44-4.64$ & Silty clay, soft, fine, very pliable & 2.5 Y $5 / 3$ \\
\hline $4.64-4.83$ & No sample & -- \\
\hline $4.83-5.10$ & Silty clay, soft, fine, high silt content, very pliable, calcareous nodules, sticky & $2.5 Y 5 / 3$ \\
\hline $5.10-5.80$ & Silty clay, stiff, very fine, iron staining, a little darker than above, slightly calcareous & $2.5 Y 5 / 3-4 / 3$ \\
\hline $5.80-5.84$ & No sample & -- \\
\hline $5.84-6.67$ & $\begin{array}{l}\text { Silty clay, soft to medium stiffness, very fine, frequent iron staining, interbedded calcareous } \\
\text { deposits (uncommon but present towards top), trace shells }\end{array}$ & $2.5 \mathrm{Y} 5 / 3$ \\
\hline $6.67-6.96$ & Silty clay to clay, soft, very pliable, iron staining & $2.5 \mathrm{Y} 5 / 3$ \\
\hline $6.96-7.09$ & No sample & -- \\
\hline $7.09-8.12$ & Silty clay to clay, occasional calcareous nodules, trace shells, soft, pliable, frequent iron staining & $5 \mathrm{Y} 5 / 2$ \\
\hline
\end{tabular}


Table 2. Detailed lithologic descriptions from continuous sediment cores.-Continued

[Munsell color classification codes are explained in Munsell Color (1992). For example, 2.5Y 4/2 gives the hue, value, and chroma of each color; where 2.5Y is the hue, 4 is the value, and 2 is the chroma. Elevation in meters above North American Vertical Datum of 1988 (NAVD 88); horizontal coordinate information referenced to Universal Transverse Mercator projection zone 14; m, meter; E., easting; N., northing; --, no data; \%, percent; cm, centimeter]

\begin{tabular}{|c|c|c|}
\hline $\begin{array}{l}\text { Depth below land } \\
\text { surface (in meters) }\end{array}$ & Lithology & Munsell color \\
\hline \multicolumn{3}{|c|}{ Continuous sediment core C3; 427,241 m E.; 4,524,262 m N.; 754.77 m above NAVD 88} \\
\hline $0-0.19$ & $\begin{array}{l}\text { Sandy silt, very fine, well sorted, well rounded, organic, roots, silty clay lens }(2.5 \mathrm{Y} 4 / 2-4 / 3) \text {, } \\
\text { slightly calcareous }\end{array}$ & 10YR 2/1 \\
\hline $0.19-0.52$ & $\begin{array}{l}\text { Silty sand, very fine to fine, well sorted, well rounded, small amounts of interbedded roots, soft, } \\
\text { mostly quartz, moderately calcareous }\end{array}$ & $2.5 Y 5 / 4-4 / 4$ \\
\hline $1.07-1.16$ & Slightly clayey silt, very fine, organic, black in color, hard, small interbedded roots & 7.5YR 2.5/1 \\
\hline $1.16-1.55$ & Silty clay, soft, very fine, minor amounts of plant material, organic & $7.5 \mathrm{YR} 3 / 1$ \\
\hline $1.55-2.16$ & Clayey silt, soft, very pliable, rolls easy & $2.5 \mathrm{Y} 5 / 3$ \\
\hline $2.16-2.32$ & Silt, soft, very fine, slight clay content & $2.5 \mathrm{Y} 5 / 3$ \\
\hline $3.78-4.64$ & $\begin{array}{l}\text { Sandy silt, very fine, soft, sand content increases towards bottom, very fine, mostly quartz, satu- } \\
\text { rated, slightly calcareous }\end{array}$ & $2.5 Y 5 / 3$ \\
\hline $4.64-5.39$ & Sandy silt, very fine, soft, saturated, slightly calcareous & $2.5 \mathrm{Y} 5 / 3$ \\
\hline $5.39-5.80$ & $\begin{array}{l}\text { Silt, very fine, soft, slight sand content, very fine, small siltstone fragments, friable, sticky, satu- } \\
\text { rated }\end{array}$ & $2.5 Y 5 / 3$ \\
\hline $5.80-6.55$ & $\begin{array}{l}\text { Sandy silt to silty sand, very fine, soft, saturated, mostly quartz, silty clay lens at bottom } \\
6.47-6.55 \mathrm{~m}(2.5 \mathrm{Y} 3 / 3) \text {, slightly calcareous }\end{array}$ & $2.5 Y 5 / 3$ \\
\hline $6.55-6.80$ & Silty clay, soft, moderately friable, slightly to moderately calcareous & $2.5 \mathrm{Y} 5 / 3$ \\
\hline $6.80-7.47$ & Clayey silt to silty clay, soft to stiff, iron staining & $2.5 Y 5 / 3$ \\
\hline $7.47-8.12$ & $\begin{array}{l}\text { Sand, fine, well sorted, well rounded, iron staining, possible organics near bottom, at bottom } \\
\text { interbedded medium to coarse gravel (rounded to subrounded), } 85 \% \text { quartz, } 10 \% \text { feldspar, and } \\
5 \% \text { mafics }\end{array}$ & $2.5 \mathrm{Y} 5 / 3$ \\
\hline $0.20-0.35$ & $\begin{array}{l}\text { Organic sandy silt, very fine, interbedded very fine sand, rich in organic material, roots frequent, } \\
\text { very dark grayish brown, soft-medium stiffness }\end{array}$ & $2.5 Y 3 / 2-2.5 / 1$ \\
\hline $0.35-0.59$ & Same as above, darker, slight clay content & $2.5 \mathrm{Y} 5 / 3$ \\
\hline $0.59-0.66$ & $\begin{array}{l}\text { Clayey silt to silty clay, very fine, interbedded very fine sand, roots, light olive brown, minor clay } \\
\text { content }\end{array}$ & $2.5 \mathrm{Y} 5 / 3$ \\
\hline $0.66-1.16$ & $\begin{array}{l}\text { Clayey silt to silty clay, soft, very fine, roots, slightly calcareous, slightly lighter in color than } \\
\text { above, moist towards bottom, moderate clay content, occasional calcareous nodules }\end{array}$ & $2.5 \mathrm{Y} 5 / 3$ \\
\hline $1.16-1.57$ & No sample & -- \\
\hline $1.57-2.32$ & $\begin{array}{l}\text { Silty clay, minor silt content, very slightly to slightly calcareous, calcareous nodules, soft, moist, } \\
\text { pliable, roots, very fine, dark grayish brown, more calcareous towards bottom }\end{array}$ & $2.5 \mathrm{Y} 4 / 3$ \\
\hline $2.32-3.07$ & No sample & -- \\
\hline $3.07-3.48$ & $\begin{array}{l}\text { Silty clay, high silt content, soft, saturated, very fine, medium to coarse gravel sized calcareous } \\
\text { nodules, sticky, slightly calcareous, very fine sand (mostly quartz) at } 3.43-3.48 \mathrm{~m}\end{array}$ & $2.5 \mathrm{Y} 5 / 3-4 / 3$ \\
\hline $3.48-4.46$ & $\begin{array}{l}\text { Silty sand, very fine, minor silt content, } 10 \% \text { mafics, } 5 \% \text { feldspar, } 85 \% \text { quartz, soft, saturated, } \\
\text { well sorted, in parts slightly calcareous }\end{array}$ & $2.5 \mathrm{Y} 5 / 3$ \\
\hline
\end{tabular}


Table 2. Detailed lithologic descriptions from continuous sediment cores.-Continued

[Munsell color classification codes are explained in Munsell Color (1992). For example, 2.5Y 4/2 gives the hue, value, and chroma of each color; where 2.5Y is the hue, 4 is the value, and 2 is the chroma. Elevation in meters above North American Vertical Datum of 1988 (NAVD 88); horizontal coordinate information referenced to Universal Transverse Mercator projection zone 14; m, meter; E., easting; N., northing; --, no data; \%, percent; cm, centimeter]

\begin{tabular}{|c|c|c|}
\hline $\begin{array}{l}\text { Depth below land } \\
\text { surface (in meters) }\end{array}$ & Lithology & Munsell color \\
\hline \multicolumn{3}{|c|}{ Continuous sediment core TM1; 390,318 m E.; 4,533,589 m N.; 800.86 m above NAVD 88-Continued } \\
\hline $4.46-4.64$ & Silty clay, soft, very fine, moderately sorted, pliable, moist, slightly calcareous in parts & $2.5 \mathrm{Y} 4 / 2$ \\
\hline $4.64-4.99$ & $\begin{array}{l}\text { Silty clay, soft, very fine, moderately sorted, pliable, moist, slightly calcareous in parts, interbed- } \\
\text { ded medium to fine sand at bottom, } 15 \% \text { feldspar, } 85 \% \text { quartz, darker color towards bottom } \\
(2.5 \mathrm{Y} 3 / 2) \text {, subrounded to rounded }\end{array}$ & $2.5 \mathrm{Y} 4 / 2$ \\
\hline $5.52-5.66$ & $\begin{array}{l}\text { Sand, fine to medium, moderately well sorted, } 90 \% \text { quartz, } 5 \% \text { feldspar, } 5 \% \text { mafics, gray clay at } \\
5.65 \text { to } 5.66 \mathrm{~m}\end{array}$ & $2.5 \mathrm{Y} 5 / 2$ \\
\hline $5.66-5.80$ & $\begin{array}{l}\text { Sand, fine to medium, poorly sorted, } 90 \% \text { quartz, } 5 \% \text { feldspar, } 5 \% \text { mafics, interbedded, subround- } \\
\text { ed coarse sand ( } 85 \% \text { quartz, } 15 \% \text { feldspar), very slight clay content }\end{array}$ & $2.5 Y 6 / 4-6 / 6$ \\
\hline $6.96-8.12$ & $\begin{array}{l}\text { Sand, medium to coarse, } 5 \% \text { mafics, } 10-15 \% \text { feldspar, mostly quartz, well sorted, some very } \\
\text { fine sand content, subrounded to rounded, interbedded fine gravel occasionally (subrounded- } \\
\text { rounded) }\end{array}$ & $2.5 \mathrm{Y} 6 / 4-6 / 3$ \\
\hline $8.12-8.94$ & No sample & -- \\
\hline $8.94-9.09$ & $\begin{array}{l}\text { Sand, very fine, well sorted, } 85 \% \text { quartz, } 10 \% \text { mafics, } 5 \% \text { feldspar, small sandstone pieces, } \\
\text { saturated }\end{array}$ & $2.5 \mathrm{Y} 5 / 3$ \\
\hline $9.09-9.28$ & $\begin{array}{l}\text { Very fine sand, interbedded with fine to coarse gravel sized sandstone chunks, angular, mostly } \\
\text { quartz }\end{array}$ & $2.5 \mathrm{Y} 5 / 3$ \\
\hline \multicolumn{3}{|c|}{ Continuous sediment core TM2; 400,104 m E.; 4,524,870 m N.; 798.68 m above NAVD 88} \\
\hline $0.16-0.25$ & $\begin{array}{l}\text { Organic silt with very fine sand, medium stiffness, friable, interbedded coarse sand grains, suban- } \\
\text { gular to subrounded, roots, very dark grayish brown, slight clay content, very fine sand mostly } \\
\text { quartz, coarse grains, } 70 \% \text { quartz, } 30 \% \text { feldspar }\end{array}$ & $2.5 Y 3 / 2$ \\
\hline $0.25-1.16$ & $\begin{array}{l}\text { Silty sand to sandy silt, very fine, well sorted, mostly quartz, moist, very slight clay content, soft, } \\
\text { slightly lighter than above in color, roots }\end{array}$ & $2.5 \mathrm{Y} 3 / 2$ \\
\hline $1.16-1.38$ & No sample & -- \\
\hline $1.38-1.47$ & $\begin{array}{l}\text { Silty sand to sandy silt, very fine, well sorted, mostly quartz, moist, very slight clay content, soft, } \\
\text { slightly lighter than above in color, roots }\end{array}$ & $2.5 \mathrm{Y} 3 / 2$ \\
\hline $1.47-2.17$ & $\begin{array}{l}\text { Silty sand, soft, well sorted, slightly calcareous, moist, very fine, mostly quartz, dark grayish } \\
\text { brown }\end{array}$ & $2.5 \mathrm{Y} 4 / 2$ \\
\hline $2.17-2.32$ & $\begin{array}{l}\text { Silty sand, soft, well sorted, slightly calcareous, moist, very fine, mostly quartz, dark grayish } \\
\text { brown }\end{array}$ & $2.5 \mathrm{Y} 4 / 3$ \\
\hline $2.32-2.55$ & No sample & -- \\
\hline $2.55-3.48$ & $\begin{array}{l}\text { Silty sand, soft, well sorted, very fine, mostly quartz, moderately calcareous, olive brown to light } \\
\text { olive brown, trace roots, moist }\end{array}$ & $2.5 Y 5 / 4-4 / 4$ \\
\hline $3.48-3.65$ & No sample & -- \\
\hline $3.65-4.64$ & $\begin{array}{l}\text { Silty sand, soft, well sorted, very fine, mostly quartz, moderately calcareous, olive brown to light } \\
\text { olive brown, moist }\end{array}$ & $2.5 Y 5 / 4-4 / 4$ \\
\hline $4.64-4.70$ & No sample & -- \\
\hline $4.70-4.96$ & $\begin{array}{l}\text { Silty sand, soft, well sorted, very fine, mostly quartz, moderately calcareous, olive brown to light } \\
\text { olive brown, moist }\end{array}$ & $2.5 Y 5 / 4-4 / 4$ \\
\hline
\end{tabular}


Table 2. Detailed lithologic descriptions from continuous sediment cores.-Continued

[Munsell color classification codes are explained in Munsell Color (1992). For example, 2.5Y 4/2 gives the hue, value, and chroma of each color; where 2.5Y is the hue, 4 is the value, and 2 is the chroma. Elevation in meters above North American Vertical Datum of 1988 (NAVD 88); horizontal coordinate information referenced to Universal Transverse Mercator projection zone 14; m, meter; E., easting; N., northing; --, no data; \%, percent; cm, centimeter]

\begin{tabular}{|c|c|c|}
\hline $\begin{array}{l}\text { Depth below land } \\
\text { surface (in meters) }\end{array}$ & Lithology & Munsell color \\
\hline & Continuous sediment core TM2; 400,104 m E.; 4,524,870 m N.; $798.68 \mathrm{~m}$ above NAVD 88—Continued & \\
\hline $5.80-5.89$ & No sample & -- \\
\hline $5.89-6.74$ & $\begin{array}{l}\text { Silty sand, very fine, soft, slightly calcareous, mostly quartz, moist to near saturated, slight clay } \\
\text { content, well sorted }\end{array}$ & $2.5 Y 5 / 4-4 / 4$ \\
\hline $6.74-6.96$ & $\begin{array}{l}\text { Silty sand, very fine, medium stiff, mostly quartz, slightly calcareous, saturated, slight clay } \\
\text { content }\end{array}$ & $2.5 Y 5 / 4-4 / 4$ \\
\hline $6.96-8.12$ & Sand, very fine, $85 \%$ quartz, $10 \%$ mafics, $5 \%$ feldspar, soft, saturated, well sorted & $2.5 Y 5 / 4-4 / 4$ \\
\hline $8.12-8.52$ & No sample & -- \\
\hline $8.52-9.24$ & $\begin{array}{l}\text { Sand, very fine, } 85 \% \text { quartz, } 10 \% \text { mafics, } 5 \% \text { feldspar, soft, saturated, well sorted, some black silt } \\
\text { streaks }\end{array}$ & $2.5 Y 5 / 4-4 / 4$ \\
\hline $0.27-0.42$ & Organic clayey silt, medium stiffness, roots, trace very fine sand, very dark grayish brown & $2.5 \mathrm{Y} 3 / 2$ \\
\hline $0.42-0.93$ & $\begin{array}{l}\text { Silty sand, silt is moderately to very stiff, friable, various colors }(2.5 \mathrm{Y} 5 / 3-4 / 3) \text { calcareous nod- } \\
\text { ules common, roots, slightly calcareous, } 90 \% \text { quartz, } 7 \% \text { feldspar, } 3 \% \text { mafics }\end{array}$ & $2.5 Y 5 / 3-4 / 3$ \\
\hline $0.93-1.16$ & $\begin{array}{l}\text { Silty sand, soft, more moist than above, moderately calcareous, well-sorted, } 90 \% \text { quartz, } \\
7 \% \text { feldspar, } 3 \% \text { mafics, roots, trace calcareous nodules }\end{array}$ & $2.5 Y 5 / 4$ \\
\hline $1.16-1.34$ & No sample & -- \\
\hline $1.34-1.50$ & $\begin{array}{l}\text { Silty sand, very fine, medium stiffness, trace clay, mostly quartz, moderately sorted, occasional } \\
\text { roots }\end{array}$ & $2.5 Y 5 / 3-4 / 3$ \\
\hline $1.50-2.07$ & Clayey silt, very dark brown, very fine, trace clay, friable, possible organic material & $2.5 Y 3 / 2$ \\
\hline $2.07-2.32$ & Silty clay, dry, olive brown, sticky and moderately pliable when wet & $2.5 \mathrm{Y} 4 / 4$ \\
\hline $4.64-4.86$ & No sample & -- \\
\hline $4.86-5.80$ & $\begin{array}{l}\text { Silty sand, very fine, } 85 \% \text { quartz, } 10 \% \text { mafics, } 5 \% \text { feldspar, well sorted, moderately calcareous, } \\
\text { soft to medium stiffness, slightly moist, trace clay }\end{array}$ & $2.5 \mathrm{Y} 5 / 3$ \\
\hline $5.80-6.04$ & No sample & -- \\
\hline $6.04-6.96$ & $\begin{array}{l}\text { Silty sand, very fine, soft, mostly quartz, well sorted, moist, trace clay, moderately calcareous, } \\
\text { light olive brown }\end{array}$ & $2.5 Y 5 / 3$ \\
\hline $6.96-7.10$ & No sample & -- \\
\hline $7.10-8.12$ & $\begin{array}{l}\text { Silty sand, very fine, soft, mostly quartz, more moist towards bottom, slightly to moderately } \\
\text { calcareous, well sorted, light olive brown, trace clay, trace calcareous nodules }\end{array}$ & $2.5 \mathrm{Y} 5 / 3$ \\
\hline $8.12-8.25$ & No sample & -- \\
\hline $8.25-8.37$ & $\begin{array}{l}\text { Silty sand, very fine, soft, mostly quartz, more moist towards bottom, slightly to moderately } \\
\text { calcareous, well sorted, light olive brown, trace clay, trace calcareous nodules }\end{array}$ & $2.5 Y 5 / 3$ \\
\hline $8.37-9.28$ & $\begin{array}{l}\text { Silty sand, very fine, soft, well sorted, mostly quartz, trace clay, moist, slightly calcareous, } \\
\text { slightly darker than above }\end{array}$ & $2.5 \mathrm{Y} 5 / 3$ \\
\hline
\end{tabular}


Table 2. Detailed lithologic descriptions from continuous sediment cores.-Continued

[Munsell color classification codes are explained in Munsell Color (1992). For example, 2.5Y 4/2 gives the hue, value, and chroma of each color; where 2.5Y is the hue, 4 is the value, and 2 is the chroma. Elevation in meters above North American Vertical Datum of 1988 (NAVD 88); horizontal coordinate information referenced to Universal Transverse Mercator projection zone 14; m, meter; E., easting; N., northing; --, no data; \%, percent; cm, centimeter]

\begin{tabular}{|c|c|c|}
\hline $\begin{array}{l}\text { Depth below land } \\
\text { surface (in meters) }\end{array}$ & Lithology & Munsell color \\
\hline \multicolumn{3}{|c|}{ Continuous sediment core 0A1; 412,917 m E.; 4,521,392 m N.; $765.08 \mathrm{~m}$ above NAVD 88} \\
\hline $0-0.19$ & No sample & -- \\
\hline $0.19-0.29$ & $\begin{array}{l}\text { Sandy clay, interbedded very fine sand, mostly quartz, low to medium stiffness, moderately pli- } \\
\text { able, black, organic, roots present }\end{array}$ & $2.5 \mathrm{Y} 2.5 / 1$ \\
\hline $0.29-1.16$ & Silty clay, soft, slightly moist, roots, moderately pliable & $2.5 \mathrm{Y} 3 / 1-3 / 2$ \\
\hline $1.34-1.44$ & Clay to silty clay, soft, moist, slightly calcareous at bottom, possible small roots, pliable & $2.5 \mathrm{Y} 4 / 2$ \\
\hline $1.44-1.57$ & $\begin{array}{l}\text { Clayey sand to sandy clay, trace silt, moderately pliable, moist, soft, very fine quartz sand, well } \\
\text { sorted, trace calcareous nodules }\end{array}$ & $2.5 \mathrm{Y} 4 / 2$ \\
\hline $1.57-1.90$ & $\begin{array}{l}\text { Clayey sand, very fine sand, soft, pliable, saturated, mostly quartz, calcareous nodules, roots, well } \\
\text { sorted, slightly calcareous, trace silt }\end{array}$ & $2.5 Y 5 / 3-5 / 4$ \\
\hline $2.32-2.62$ & No sample & -- \\
\hline $2.62-3.08$ & $\begin{array}{l}\text { Clayey sand to sandy clay, soft, pliable, sand is very fine and well sorted, mostly quartz, moist, } \\
\text { roots, trace calcareous nodules }\end{array}$ & $2.5 \mathrm{Y} 5 / 3$ \\
\hline $3.08-3.48$ & $\begin{array}{l}\text { Clayey sand to sandy clay, soft, pliable, sand is very fine and well sorted, mostly quartz, moist, } \\
\text { roots, frequent calcareous nodules, lens of very fine to fine well sorted sand }(2.5 \mathrm{Y} 5 / 3-4 / 3) \\
\text { from } 3.44 \text { to } 3.48 \mathrm{~m}, 85 \% \text { quartz, } 10 \% \text { mafics, } 5 \% \text { feldspar }\end{array}$ & $2.5 \mathrm{Y} 5 / 3$ \\
\hline $3.48-4.20$ & $\begin{array}{l}\text { Sand, very fine, well sorted, occasional interbedded subrounded medium sand grains, } 10 \% \text { maf- } \\
\text { ics, } 5 \% \text { feldspar, } 85 \% \text { quartz }\end{array}$ & $2.5 Y 5 / 3$ \\
\hline $4.20-4.56$ & $\begin{array}{l}\text { Sand, very fine to fine, saturated, } 85 \% \text { quartz, } 10 \% \text { mafics, about } 5 \% \text { feldspar, interbedded, sub- } \\
\text { rounded coarse sand grains, moderately well sorted }\end{array}$ & $2.5 \mathrm{Y} 5 / 3$ \\
\hline $6.58-7.67$ & $\begin{array}{l}\text { Sand, fine, } 10 \% \text { mafics, } 10 \% \text { feldspar, } 80 \% \text { quartz, interbedded coarse sand subrounded, occa- } \\
\text { sional fine gravel: subrounded, well sorted }\end{array}$ & $2.5 \mathrm{Y} 6 / 3$ \\
\hline $7.67-8.75$ & $\begin{array}{l}\text { Sand, medium to coarse, rounded to subrounded, } 75 \% \text { quartz, } 10 \% \text { mafics, } 15 \% \text { feldspar, inter- } \\
\text { bedded subrounded fine gravel, } 80 \% \text { quartz, } 20 \% \text { feldspar }\end{array}$ & $2.5 \mathrm{Y} 6 / 3$ \\
\hline \multicolumn{3}{|c|}{ Continuous sediment core 0A2; 416,670 m E.; 4,514,037 m N.; $764.56 \mathrm{~m}$ above NAVD 88} \\
\hline $0-0.32$ & No sample & -- \\
\hline $0.32-0.89$ & $\begin{array}{l}\text { Silty sand, very fine, moderately to well sorted, mostly quartz, soft, lens of organic silt } \\
(2.5 \mathrm{Y} 3 / 1-3 / 2 \text {, many roots in first } 4 \mathrm{~cm})\end{array}$ & $2.5 Y 5 / 3$ \\
\hline $0.89-1.16$ & $\begin{array}{l}\text { Silty sand, very fine, well sorted, soft, mostly quartz, slightly calcareous, trace calcareous } \\
\text { nodules, lens of silty clay to clayey silt ( } 2.5 \mathrm{Y} 2.5 / 1 \text {, black, moist, low pliability, soft, slightly } \\
\text { calcareous) from } 1.12 \text { to } 1.16 \mathrm{~m}\end{array}$ & $2.5 \mathrm{Y} 4 / 4$ \\
\hline $1.16-1.41$ & No sample & -- \\
\hline $1.41-1.65$ & Silty clay, minor silt content, moist, pliable, soft to moderately stiff, very dark grayish brown & $2.5 \mathrm{Y} 3 / 2$ \\
\hline $1.65-2.09$ & $\begin{array}{l}\text { Silty clay, moderate silt content, moist, slightly pliable, soft, medium stiffness, very fine, grayish } \\
\text { brown to dark grayish brown }\end{array}$ & $2.5 Y 5 / 2-4 / 2$ \\
\hline
\end{tabular}


Table 2. Detailed lithologic descriptions from continuous sediment cores.-Continued

[Munsell color classification codes are explained in Munsell Color (1992). For example, 2.5Y 4/2 gives the hue, value, and chroma of each color; where 2.5Y is the hue, 4 is the value, and 2 is the chroma. Elevation in meters above North American Vertical Datum of 1988 (NAVD 88); horizontal coordinate information referenced to Universal Transverse Mercator projection zone 14; m, meter; E., easting; N., northing; --, no data; \%, percent; cm, centimeter]

\begin{tabular}{|c|c|c|}
\hline $\begin{array}{l}\text { Depth below land } \\
\text { surface (in meters) }\end{array}$ & Lithology & Munsell color \\
\hline \multicolumn{3}{|c|}{ Continuous sediment core 0A2; 416,670 m E.; 4,514,037 m N.; $764.56 \mathrm{~m}$ above NAVD 88-Continued } \\
\hline $2.32-2.50$ & No sample & -- \\
\hline $2.50-2.80$ & Silty clay, moderate silt content, sticky, saturated, soft, pliable, slightly calcareous & $2.5 Y 3 / 1-3 / 2$ \\
\hline $3.48-3.57$ & No sample & -- \\
\hline $3.57-4.64$ & $\begin{array}{l}\text { Sandy clay to clayey sand, soft, very fine, } 85 \% \text { quartz, } 10 \% \text { mafics, } 5 \% \text { feldspar, pliable, well to } \\
\text { moderately sorted, very moist, trace silt, saturated, slightly calcareous in parts, lens of slightly } \\
\text { calcareous from } 3.57 \text { to } 3.66 \mathrm{~m}\end{array}$ & $2.5 Y 5 / 3$ \\
\hline $5.80-5.86$ & No sample & -- \\
\hline $5.86-6.45$ & $\begin{array}{l}\text { Clay, soft, frequent calcareous nodules, some iron staining, slightly calcareous, moist, lens of clay } \\
\text { (gray, pliable, soft, moist) from } 5.86 \text { to } 5.90 \mathrm{~m}\end{array}$ & $2.5 Y 5 / 3$ \\
\hline $6.45-6.96$ & $\begin{array}{l}\text { Clayey sand to silty sand, moderately pliable, sand is very fine and predominantly quartz, moist, } \\
\text { soft, slightly calcareous, iron staining, calcareous deposits less common than above, some clay }\end{array}$ & $2.5 \mathrm{Y} 5 / 3$ \\
\hline $6.96-7.10$ & No sample & -- \\
\hline $7.10-8.12$ & $\begin{array}{l}\text { Silty sand, soft, very fine, mostly quartz, slightly to moderately calcareous, well sorted, iron } \\
\text { staining, trace clay at bottom }\end{array}$ & $2.5 \mathrm{Y} 6 / 3-5 / 3$ \\
\hline \multicolumn{3}{|c|}{ Continuous sediment core K1; 487,893 m E.; 4,505,579 m N.; $677.42 \mathrm{~m}$ above NAVD 88} \\
\hline $0-0.15$ & No sample & -- \\
\hline $0.74-0.84$ & $\begin{array}{l}\text { Clay, soft-medium stiff, pliable, very slightly calcareous, patches of very dark grayish brown } \\
(2.5 \text { Y } 3 / 2) \text {, small amount of plant matter }\end{array}$ & $2.5 \mathrm{Y} 4 / 2$ \\
\hline $0.84-0.98$ & $\begin{array}{l}\text { Sandy silt, possible organics, interbedded coarse-medium sand grains (mostly quartz, } 15 \% \text { feld- } \\
\text { spar, moderately calcareous), patches of yellowish orange staining (very slightly calcareous), } \\
\text { soft, fine silt }\end{array}$ & $2.5 \mathrm{Y} 3 / 2$ \\
\hline $0.98-1.16$ & $\begin{array}{l}\text { Clayey silts, low plasticity, soft to medium stiffness, interbedded fine gravel sized concrete clasts } \\
\text { grading to interbedded coarse-medium sand ( } 15 \% \text { feldspar, } 85 \% \text { quartz, uncommon mafics, } \\
\text { subangular to subrounded), concrete moderately calcareous }\end{array}$ & $2.5 \mathrm{Y} 3 / 2-2.5 / 1$ \\
\hline $1.16-1.56$ & No sample & -- \\
\hline $1.56-1.69$ & Concrete, coarse gravel sized, moderately calcareous & $2.5 \mathrm{Y} 5 / 2$ \\
\hline $1.69-2.32$ & Clay, very slight silt content, very pliable, high plasticity, soft, stiffer towards bottom & $2.5 Y 3 / 2$ \\
\hline $2.32-2.55$ & No sample & -- \\
\hline $2.55-2.79$ & Silty sand, very fine, saturated, mostly quartz, very soft, well sorted & $2.5 \mathrm{Y} 4 / 2$ \\
\hline
\end{tabular}


Table 2. Detailed lithologic descriptions from continuous sediment cores.-Continued

[Munsell color classification codes are explained in Munsell Color (1992). For example, 2.5Y 4/2 gives the hue, value, and chroma of each color; where 2.5Y is the hue, 4 is the value, and 2 is the chroma. Elevation in meters above North American Vertical Datum of 1988 (NAVD 88); horizontal coordinate information referenced to Universal Transverse Mercator projection zone 14; m, meter; E., easting; N., northing; --, no data; \%, percent; cm, centimeter]

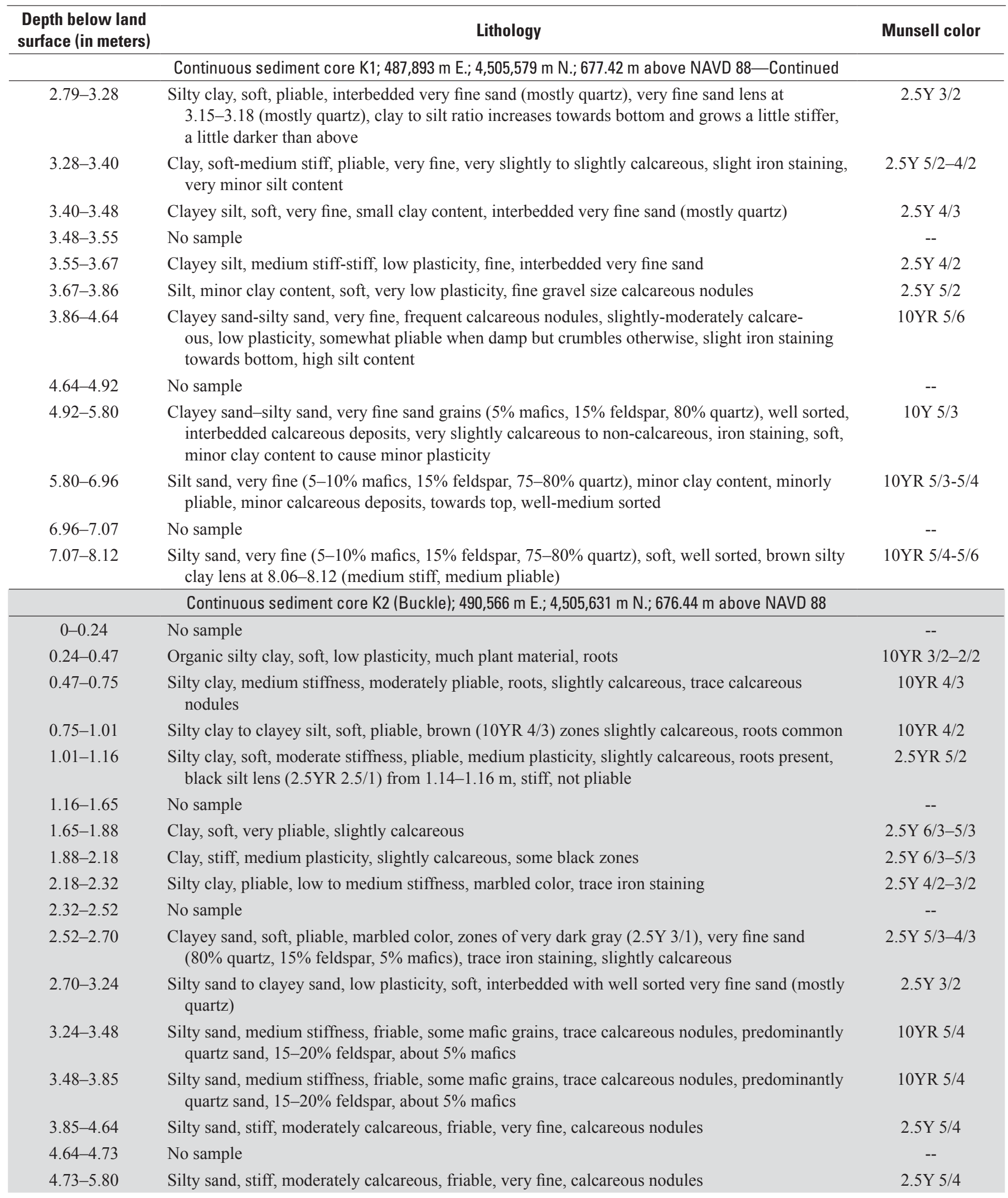


Table 2. Detailed lithologic descriptions from continuous sediment cores.-Continued

[Munsell color classification codes are explained in Munsell Color (1992). For example, 2.5Y 4/2 gives the hue, value, and chroma of each color; where 2.5Y is the hue, 4 is the value, and 2 is the chroma. Elevation in meters above North American Vertical Datum of 1988 (NAVD 88); horizontal coordinate information referenced to Universal Transverse Mercator projection zone 14; m, meter; E., easting; N., northing; --, no data; \%, percent; cm, centimeter]

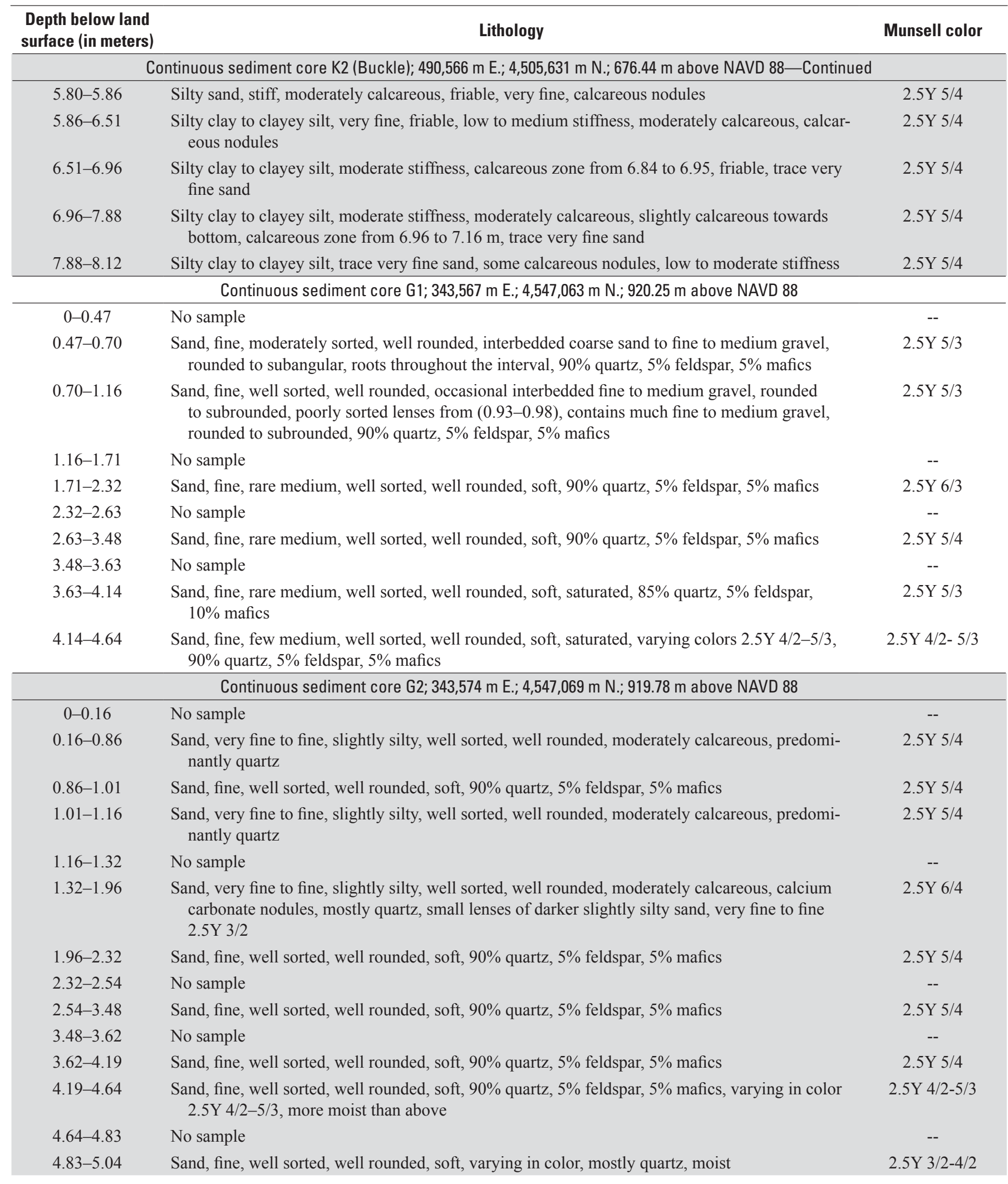


Table 2. Detailed lithologic descriptions from continuous sediment cores.-Continued

[Munsell color classification codes are explained in Munsell Color (1992). For example, 2.5Y 4/2 gives the hue, value, and chroma of each color; where 2.5Y is the hue, 4 is the value, and 2 is the chroma. Elevation in meters above North American Vertical Datum of 1988 (NAVD 88); horizontal coordinate information referenced to Universal Transverse Mercator projection zone 14; m, meter; E., easting; N., northing; --, no data; \%, percent; cm, centimeter]

\begin{tabular}{|c|c|c|}
\hline $\begin{array}{l}\text { Depth below land } \\
\text { surface (in meters) }\end{array}$ & Lithology & Munsell color \\
\hline \multicolumn{3}{|c|}{ Continuous sediment core G2; 343,574 m E.; 4,547,069 m N.; $919.78 \mathrm{~m}$ above NAVD 88-Continued } \\
\hline $5.43-5.80$ & $\begin{array}{l}\text { Sand, fine, well sorted, well rounded, soft, moist, varying in color, grades into a darker grayish } \\
\text { brown slightly silty sand toward the bottom, very fine }\end{array}$ & $2.5 Y 4 / 2-5 / 2$ \\
\hline $5.80-6.10$ & Sand, fine, well sorted, well rounded, soft, saturated, $85 \%$ quartz, $5 \%$ feldspar, $10 \%$ mafics & $2.5 \mathrm{Y} 5 / 4$ \\
\hline $6.76-6.96$ & Silty sand, very fine to fine, well rounded, well sorted, saturated, mostly quartz & $2.5 \mathrm{Y} 5 / 3$ \\
\hline $6.96-8.12$ & Silty sand, very fine, well sorted, well rounded, saturated, soft, mostly quartz & $2.5 \mathrm{Y} 6 / 3$ \\
\hline \multicolumn{3}{|c|}{ Continuous sediment core G3; 343,555 m E.; 4,547,089 m N.; $919.56 \mathrm{~m}$ above NAVD 88} \\
\hline $0-0.18$ & No sample & -- \\
\hline $1.16-1.33$ & No sample & -- \\
\hline $1.33-2.32$ & Sand, fine, well sorted, well rounded, soft, $90 \%$ quartz, $5 \%$ feldspar, $5 \%$ mafics & $2.5 \mathrm{Y} 5 / 4$ \\
\hline $2.32-2.61$ & No sample & -- \\
\hline $2.61-3.48$ & Sand, fine, well sorted, well rounded, soft, $90 \%$ quartz, $5 \%$ feldspar, $5 \%$ mafics & $2.5 \mathrm{Y} 5 / 4$ \\
\hline $3.48-4.64$ & Sand, fine, few medium, well sorted, well rounded, moist, $85 \%$ quartz, $5 \%$ feldspar, $10 \%$ mafics & $2.5 \mathrm{Y} 5 / 3$ \\
\hline \multicolumn{3}{|c|}{ Continuous sediment core G4; 343,549 m E.; 4,547,083 m N.; 919.70 m above NAVD 88} \\
\hline $0-0.30$ & No sample & -- \\
\hline $0.30-0.53$ & $\begin{array}{l}\text { Sand, fine, few medium, moderately sorted, well rounded, interbedded coarse sand to fine gravel, } \\
\text { rounded to subrounded, } 90 \% \text { quartz, } 5 \% \text { feldspar, } 5 \% \text { mafics }\end{array}$ & $2.5 \mathrm{Y} 5 / 4$ \\
\hline $0.53-1.16$ & Sand, fine, well sorted, well rounded, soft, $90 \%$ quartz, $5 \%$ feldspar, $5 \%$ mafics & $2.5 \mathrm{Y} 5 / 4$ \\
\hline $4.24-4.64$ & $\begin{array}{l}\text { Sand, fine, well sorted, well rounded, soft, moist, varying in color, } 2.5 \mathrm{Y} 4 / 2-5 / 4,90 \% \text { quartz, } \\
5 \% \text { feldspar, } 5 \% \text { mafics }\end{array}$ & $2.5 \mathrm{Y} 4 / 2-5 / 4$ \\
\hline $4.64-5.80$ & Sand, fine, well sorted, well rounded, soft, saturated, $85 \%$ quartz, $5 \%$ feldspar, $10 \%$ mafics & $2.5 \mathrm{Y} 5 / 3$ \\
\hline $5.80-5.93$ & No sample & -- \\
\hline $5.93-6.96$ & $\begin{array}{l}\text { Sand, fine, few medium, well sorted, well rounded, soft, saturated, grades to very fine sand to- } \\
\text { ward the bottom, } 85 \% \text { quartz, } 5 \% \text { feldspar, } 10 \% \text { mafics }\end{array}$ & $2.5 Y 5 / 3$ \\
\hline
\end{tabular}




\section{Cozad Canal}

$\mathrm{CC}$ resistivity data were collected from the eastern edge of Gothenburg eastward to where Cozad Canal empties into Dawson County Canal (figs. 1 and 17A). Because the canal bed remained submerged during the spring of 2012, all CC data west of the crossing at Road 421 were collected along the canal bank. All data east of the crossing at Road 421 were collected on top of the canal bed (fig. 17A). Small sections of canal were omitted because of low bridge crossings and weirs or other structures. In April 2012, before the onset of diversions into the canal, an RTK GPS survey of the elevation of the canal bed westward from the Road 421 crossing was completed. At the time of the survey the canal bed remained inundated but was wadeable.

The CC resistivity results are presented as a map of vertically averaged resistivity of materials underlying Cozad Canal (fig. 17A). For the western part of Cozad Canal, this average resistivity includes the partial section from the top of the canal bank to the elevation of the canal bed, which is typically finergrained, as well as for the remainder of the section deeper than the canal bed. It is important to note that including the upper section above the canal bed may bias the vertically averaged resistivity low for this upstream part. The authors have chosen to average the entire vertical section, as was done in Burton and others (2009), because inverted resistivity depth sections are composed of seven depth samples that are spaced at increasingly greater distances with depth. Selecting the correct upper bounding sample for the average resistivity can be problematic. Examining the inverted resistivity sections displayed in figures $5 C$ and $6 C$, the resistivity above the canal bed and below display similar resistivity patterns and values, and therefore this biasing would appear to be minimal. The upstream part of Cozad Canal was the most resistive, as exemplified near the location of core $\mathrm{C} 1$ (figs. 5 and 17A). The upper $4.3 \mathrm{~m}$ of core $\mathrm{C} 1$ was described as finer deposits of sandy silt,silty clay, and clayey silt, which overlie a mix of medium to coarse sand (fig. 5 and table 2). The elevation of the canal bed (indicated as the black horizontal line in fig. $5 \mathrm{C}$ ) roughly coincides with the top of the coarser deposits in core $\mathrm{C} 1$. In general, the zones with the highest resistivity, and therefore the coarsest deposits, were west of core $\mathrm{C} 1$ along the upper end of the surveyed reach (fig. 17A). To the east of core $\mathrm{C} 1$, the deposits mapped were fairly uniform and generally had lower resistivity compared to the reach to the west. Core $\mathrm{C} 2$ was described as a mix of silt and clay to silty clay (fig. 6 and table 2). In this middle reach, the canal courses in an easterly direction and is more distant from the modern Platte River, which courses southeast (fig. 17A). It appears that the thickness of finer, overbank deposits of silt and clay increases as distance from the Platte River lengthens. To the east of core C2, to the Road 421 crossing, the average resistivity generally remained low (less than $30 \mathrm{ohm}-\mathrm{m}$ ). East of Road 421, zones of increased resistivity were surveyed. Core $\mathrm{C} 3$ was collected $450 \mathrm{~m}$ from the eastern end of the surveyed reach (figs. 7 and 17A). The upper $7.47 \mathrm{~m}$ of core $\mathrm{C} 3$ is described as a mix of finer grained sediments, which overlie well sorted fine sand (fig. 7 and table 2 ). The zones of increased vertically averaged resistivity from the Road 421 crossing and C3 are interpreted to be zones of increased sand content.

\section{Thirty-Mile Canal}

In spring 2012, CC resistivity data were collected on top of the canal bed, beginning approximately $3.2 \mathrm{~km}$ downstream from the diversion point and extending approximately $27 \mathrm{~km}$ to the southeast (figs. 2 and 17A). Within the surveyed reach, short lengths of canal were omitted because of low bridge crossings, weirs or check structures, or short reaches of ponded water on the canal bed. An 11-km reach toward the lower end of Thirty-Mile Canal was not surveyed because the canal banks were extremely steep and high, presenting difficulty and safety concerns with lowering the ATV safely into the bottom of the canal. This reach of the canal is located against the south valley wall and is frequently crossed by siphons and check structures. Furthermore, county roads do not cross the canal as frequently, making access more difficult. At its lower end, a shorter reach of Thirty-Mile Canal turns north from the valley wall and crosses the Platte River valley. In spring 2013, $\mathrm{CC}$ resistivity data were collected along this lower reach, with surveying along the top of the canal bank because the frequency of check structures on the canal bed would have prevented a continuous dataset, and because the canal in most locations was narrower than the width of the ATV. No GPS data were collected along the canal bed of this lower reach to determine its elevation. Generally speaking, the difference in elevation between the canal bed and the top of the bank was less than 1 to $2 \mathrm{~m}$.

The $\mathrm{CC}$ resistivity results are presented as a map of vertically averaged resistivity of materials underlying ThirtyMile Canal (fig. 17A). In general, the subsurface of the upper $3 \mathrm{~km}$ of Thirty-Mile Canal was more resistive compared to that for most of the surveyed reaches to the east (fig. 17A). Core TM1 exemplifies and was collected within this more resistive zone; core lithology was described as $5.52 \mathrm{~m}$ of finer grained material overlying an interval of fine to medium sand (fig. 8 and table 2). Lower average resistivities were measured eastward beyond the initial $3 \mathrm{~km}$ until reaching the vicinity of core TM2. Vertically averaged resistivities ranged from 15 to $30 \mathrm{ohm}-\mathrm{m}$ in the area of core TM2. Core TM2 was described as $7 \mathrm{~m}$ of silty sand overlying well sorted, very fine sand (fig. 9 and table 2). East of core TM2, the reach extending to core TM3 generally had average resistivities that ranged from 10 to $40 \mathrm{ohm}-\mathrm{m}$ with the highest average values in the 1-km stretch immediately upstream from core TM3 (fig. 17A). Core TM3 was described as having $1.50 \mathrm{~m}$ of silty sand grading into about $3.2 \mathrm{~m}$ of silty clay. This sequence of finer material overlies $4.4 \mathrm{~m}$ of silty sand (fig. 10 and table 2). The 3-km reach east of core TM3 also had average resistivities ranging from 10 to $40 \mathrm{ohm}-\mathrm{m}$ (fig. 17A). Near the eastern end of the canal, the second, or lower, surveyed reach of the canal 
courses north and east from the valley wall toward the Platte River. This reach generally had higher average resistivity (up to $80 \mathrm{ohm}-\mathrm{m}$ ) than did the upper reach, despite the canal bank material contributing to the average for the lower reach.

\section{Orchard-Alfalfa Canal}

$\mathrm{CC}$ resistivity data were collected along Orchard-Alfalfa Canal, extending from the upper reach near the historical south bank of the Platte River, about $3.2 \mathrm{~km}$ west of Highway 21 downstream to a point directly south of the Cozad Interchange at Interstate 80 (fig. 17A). All data were collected on top of the canal bed. Short lengths of the canal were omitted because of low bridge crossings, weirs or check structures, or thick tree cover that limited the accuracy of the GPS data.

Generally, the vertically averaged resistivity ranged from 15 to $30 \mathrm{ohm}-\mathrm{m}$ for the surveyed reach of Orchard-Alfalfa Canal (fig. 17A). Core OA1 was collected at the upper end of the surveyed reach. The upper $3.5 \mathrm{~m}$ of core OA1 was described as clayey sand to sandy clay and had a resistivity of less than $20 \mathrm{ohm}-\mathrm{m}$ (fig. 11 and table 2). This finer-grained interval overlies fine sand that grades into coarse sand at the bottom of the cored interval. The EC log indicates low resistivity deposits just beneath this sampled interval. Measured CC resistivity data also indicate this low resistivity layer may extend laterally at a depth of approximately $8 \mathrm{~m}$ below the canal bed, though uncertainty about this layer is large, because it lies at the extreme bottom of the inverted section (fig. 11). Eastward, the vertically averaged resistivity was fairly uniform before decreasing at approximately $1.5 \mathrm{~km}$ downstream from core OA1 (fig. 17A), where the canal enters a reach of lower average resistivity (less than $20 \mathrm{ohm}-\mathrm{m}$ ) that extends to approximately $5 \mathrm{~km}$ upstream from core OA2. From core OA2, to further downstream, the average resistivity increased slightly (20 to $30 \mathrm{ohm}-\mathrm{m}$ ); this reach extends downstream $2.5 \mathrm{~km}$ before encountering less resistive bed materials. Core OA2 was collected near the end of the surveyed reach in an area with the lowest average resistivities (less than $20 \mathrm{ohm}-\mathrm{m}$ ) and at greatest distance from the Platte River (figs. 12 and 17A). Below the upper $1.4 \mathrm{~m}$ to a depth of $5.8 \mathrm{~m}$, core OA2 is composed mostly of silty and sandy clay to clayey sand with varying amounts of very fine sand (fig. 12 and table 2). Results from the EC log indicated a uniformly low resistivity (10 to $20 \mathrm{ohm}-\mathrm{m}$ ) to a depth equal to the cored interval, indicative of fine-grained deposits, which agrees well with the inverted $\mathrm{CC}$ resistivity data (fig. 12).

\section{Kearney Canal}

$\mathrm{CC}$ resistivity data were collected from the hydroelectric plant in the City of Kearney to Dove Hill Road approximately $8 \mathrm{~km}$ to the west (fig. 17B). The western $5 \mathrm{~km}$ of the surveyed reach of the Kearney Canal is situated at the north valley wall of the Platte River valley. The eastern $3 \mathrm{~km}$ of the canal was cut into Quaternary loess deposits north of the valley. For this survey, all data were collected on top of the canal bed. Short lengths of canal were omitted because of low bridge crossings, city streets, and county roads. Cultural noise from overhead power lines and buried utilities also resulted in some omitted sections, where it produced elevated noise levels in the measured data.

The purpose of this survey was to investigate the extent of a known focused seepage area. The area of focused seepage is less than $100 \mathrm{~m}$ to the west of core K2 (Buckle). CC-resistivity profiles indicated a consistent resistivity pattern: a 4- to 5-m thick section of more resistive material (50 to $90 \mathrm{ohm}-\mathrm{m}$ ) overlies 3 or $4 \mathrm{~m}$ of lower-resistivity material (less than $15 \mathrm{ohm}-\mathrm{m}$ ) (figs. 13 and 14). This trend of more highly resistive material overlying less resistive material generally continued across the entire 8-km reach, with some short interruptions (figs. 13 and 14). Slightly higher vertically averaged resistivities were indicated along the western part of the surveyed reach where the Kearney Canal lies at the north edge of the Platte River valley (fig. 17B). Given the generally consistent trend of the inverted CC-resistivity data, evidence for a focused seepage area is absent. The inverted data cannot indicate whether small, hydrologically significant features, such as macropores, may be present; such features are small and rare enough as to be unresolvable with this technique. The inconclusive results also indicate that the CC-resistivity method is more suitable for mapping general leakage trend where lithology is the primary control rather than small discrete features.

The resistivity measured with the EC logging system (10 to $20 \mathrm{ohm}-\mathrm{m}$ ) is roughly one-fifth of the resistivity values in the average inverted CC-resistivity sections near both cores along Kearney Canal (figs. 13 and 14). Sediment cores were collected on the canal bank in April 2012, after river water had been diverted into Kearney Canal. The CC-resistivity data, however, had been acquired before the diversion, when sediments are assumed to have been drier, and therefore more resistive. The difference in moisture content between the surveys could explain the discrepancy between the measured resistivity values in EC logs and inverse modeling results. The presence of water in the canal and surrounding materials would also explain the more muted resistivity structure (the resistivity features are less distinct) observed at depths lower than the canal bed in the EC logs as compared to the EC logs from the other canals. The water introduced into the system can have a sufficiently low resistivity to reduce the overall resistivity contrast between lithologic layers. A similar hypothesis also was noted in Ball and others (2006), where comparisons of dry and wet (flowing) canals were shown to affect the subsurface resistivity values, but resistivity contrasts and resistivity structures were accurately recovered in both scenarios. 


\section{Outlet Canal}

CC- and DC-resistivity data were collected at Outlet Canal along a $5-\mathrm{km}$ reach near the seep near Outlet Canal MP 15.55 (fig. 3A). Two lines of CC-resistivity data were collected, along the north and south edges of the north access road of the canal, and one line was collected at the toe of the north canal bank. DC-resistivity measurements were collected along five lines near Outlet Canal (fig. 3B).

Four continuous sediment cores were collected at the intersections of the two canal roadside lines with the two tie lines (fig. 3B). The location of the EC logs were superimposed on the canal roadside resistivity sections and profiles (figs. 15 and 16). The EC logs show good agreement with the inverted $\mathrm{CC}$-resistivity sections. For the canal roadside north model (G2 and G3; fig. 16), the general trend is lower resistivity in the top $1.5 \mathrm{~m}$, then high resistivity for the next $3 \mathrm{~m}$ or so, and a transition to lower values for the last $4.7 \mathrm{~m}$. For the canal roadside south model (G1 and G4; fig. 15), the general trend is a gradual transition from high resistivity near the surface to lower resistivity at depth. A comparison of the DC-resistivity and CC-resistivity inversion models is shown in figs. 18 and 19. Generally, both sets of inversion models agree with one another.

One of the objectives of these surveys was to ascertain the depth, and possibly the condition, of the original compacted-core bank structure. The NPPD provided a schematic diagram (Edward Dekleva Jr., written commun., 2012) showing a cross section through the embankment near piezometer PZ-5, intersecting the two surveyed canal roadside lines (fig. 20). Piezometer PZ-5 is roughly in the middle between the two tie profiles. From the schematic diagram, the depth was estimated to the northern sloping surface of the original compacted-core bank beneath the canal roadside lines. Also, the depth to the northern slope of the buried bank surface after its first modification was estimated beneath the north canal road lines. The depth to water in piezometer PZ-4 (fig. $3 B$ ), located approximately $120 \mathrm{~m}$ southeast of PZ-5 along the canal road, was measured $3.85 \mathrm{~m}$ below land surface on April 18, 2012. For display purposes this water level was superimposed on the DC-resistivity inversion models (fig. 21).

Along the canal road south line (fig. $21 E$ ), there is a transition from high resistivity at land surface to much lower resistivity near the estimated depth of the northern slope of the original compacted-core bank; however, the surveyed elevation of the water surface in the canal on April 20, 2012, also was at this elevation, about $917 \mathrm{~m}$ (NPPD datum). Currently (2013), it is unknown if the indicated change in resistivity at this elevation was the effect of saturation of the underlying sediments or caused by the compacted-core bank. If the core bank caused the detected contrast, then the lack of substantial variation in resistivity beneath the surface of the compactedcore bank suggests the compacted-core bank material was relatively homogeneous at this location.

Along the canal road north line (fig. $21 D$ ), there is a transition from high resistivity near land surface to lower resistivity at depth. Although the transition is rapid near the estimated depth of the first-modified bank slope, it is not clear that this change is related to either the original core bank structure or its later modifications. There is substantially more horizontal and vertical variation in resistivity in the north profile relative to the south inversion models.

Water-surface elevations were surveyed at the time of the resistivity survey. The water level in PZ-4 was measured as $915 \mathrm{~m}$ (NPPD datum), which is about $2 \mathrm{~m}$ lower than the surveyed water level in the canal. PZ-4 is within a meter of the north roadside line (for both CC- and DC-resistivity profiles). The water ponded at the base of the embankment has a watersurface elevation of about $913 \mathrm{~m}$ (NPPD datum).

The inverted CC-resistivity models for the two canalroadside lines on either side of the seep near Outlet Canal MP 15.55 were compared visually and evaluated (figs. 22 and 23). Resistivity features in the area of the seep at MP 15.55 do not seem substantially different than those located elsewhere in the modeled CC-resistivity sections along this reach.

The results of the surface resistivity surveys were inconclusive regarding identification of resistivity features in the embankment that are related to canal seepage at low-flow levels. Because NPPD personnel have noticed an apparent relation between seepage rates and canal flow rates, it may be advantageous to resurvey the same areas again when water level in the canal is higher. The groundwater level at the time of the surveys was similar in elevation beneath the compacted-core bank beneath the north resistivity roadside line. Furthermore, the canal water level was similar in elevation to the compacted-core bank beneath the south roadside profile. Above these elevations on both profiles, the resistivity is much higher. During times when the water-surface elevation of the canal is higher, focused seepage may occur through these areas of higher resistivity. With saturation, the resistivity therein is expected to decrease, potentially making a detectable contrast with drier areas. An additional DC-resistivity survey could identify features or zones of preferential flow within the canal bank provided the electrode spacing was short enough to resolve the vertical and horizontal extents of these preferential flow zones. 


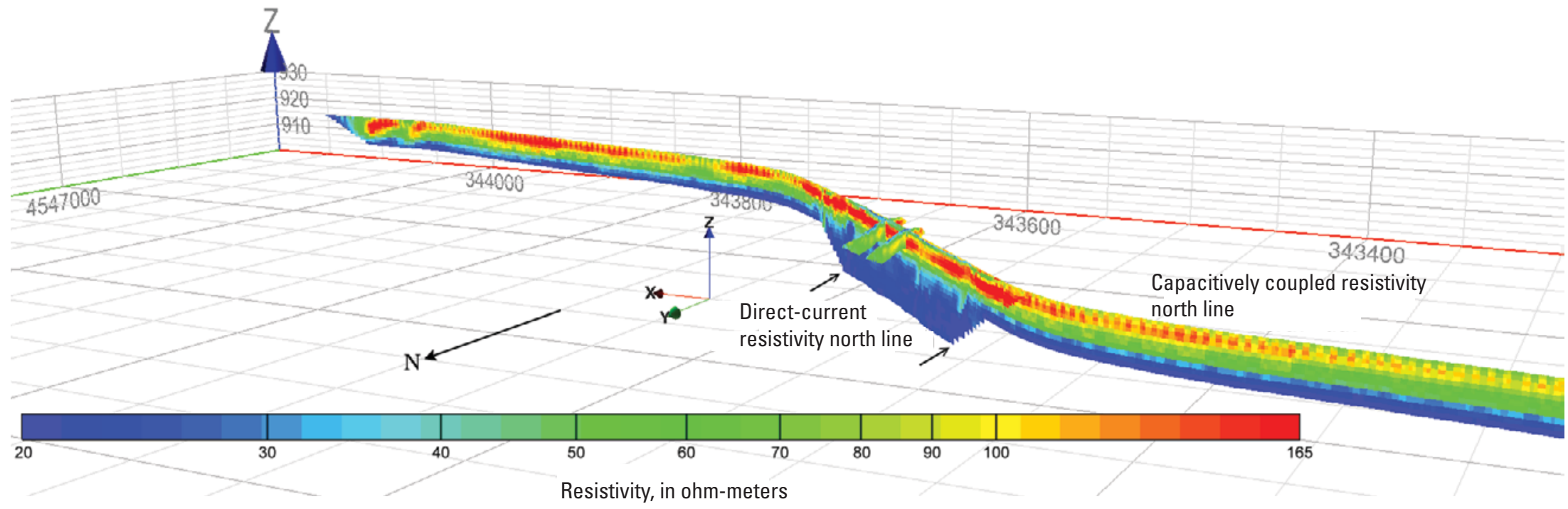

Universal Transverse Mercator projection, zone 14

Northing and Easting coordinates given in meters,

Referenced to the North American Datum of 1983

Elevation given in meters above North American Vertical Datum of 1988

Figure 18. Section showing results from an inverted capacitively coupled resistivity model and an inverted direct-current resistivity model along Outlet Canal access road north line. Small arrows indicate lower-lateral extent of the direct-current resistivity model. $X, y$, and $z$ are easting, northing, and elevation in meters. 


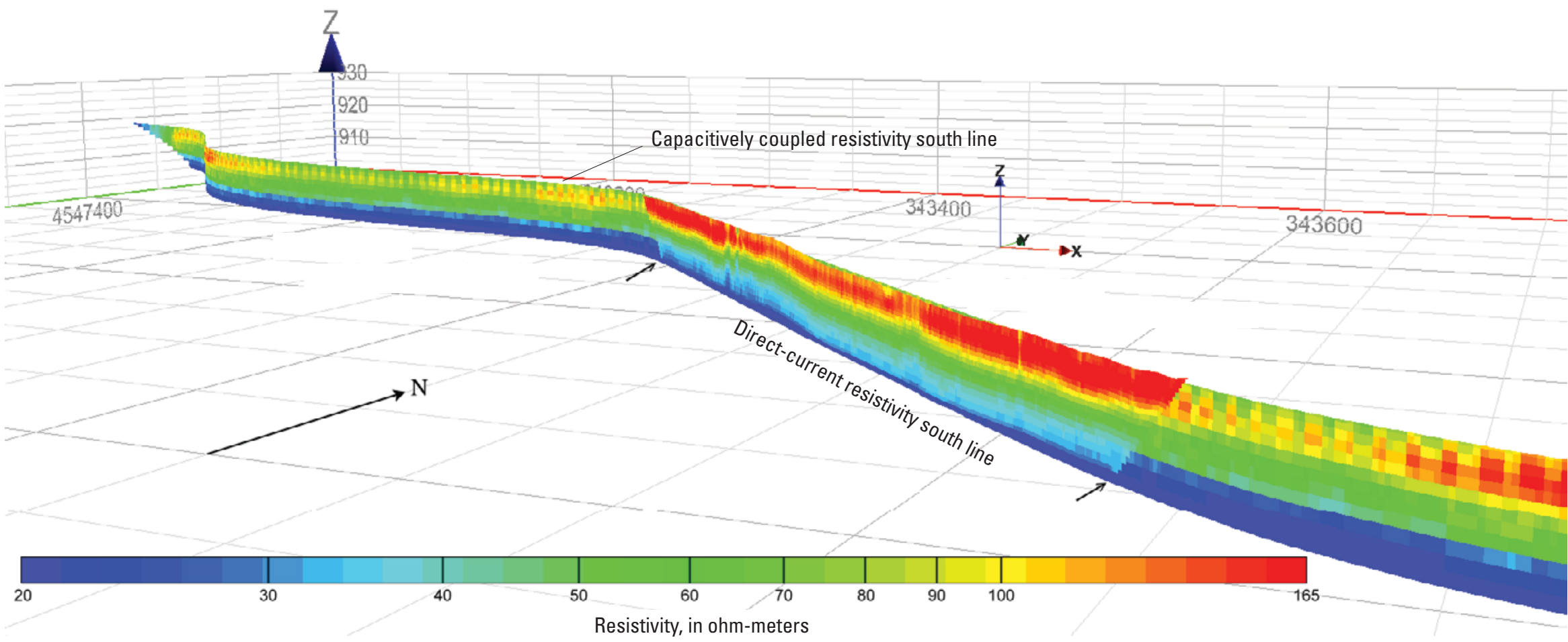

Universal Transverse Mercator projection, zone 14

Northing and Easting coordinates given in meters,

Referenced to the North American Datum of 1983

Elevation given in meters above North American Vertical Datum of 1988

Figure 19. Section showing results from an inverted capacitively coupled resistivity model and an inverted direct-current resistivity model along Outlet Canal access road south line. Small arrows indicate lower-lateral extent of the direct-current resistivity model. $X, y$, and $z$ are easting, northing, and elevation in meters. 


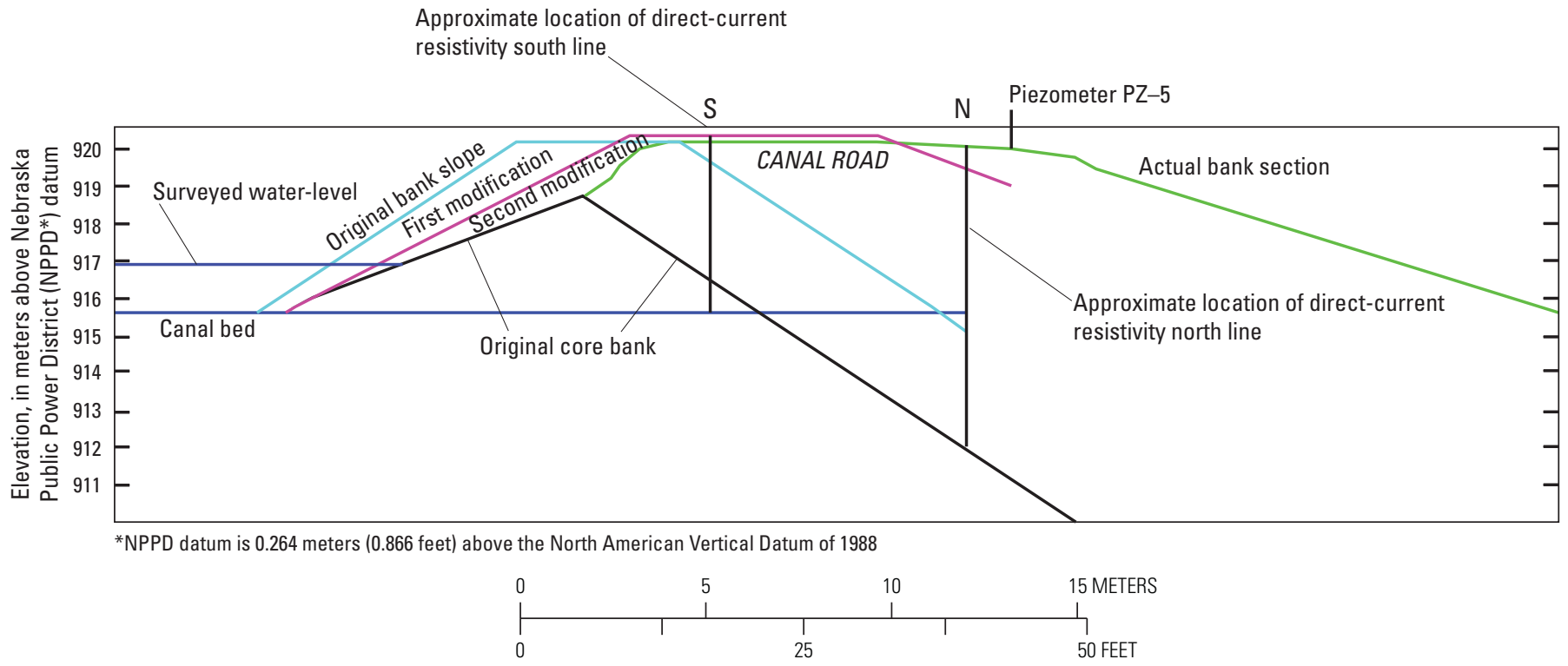

Figure 20. Schematic cross-sectional diagram of north bank of Outlet Canal near mile post 15.55 showing remnant of original compacted-core bank and its modifications with respect to location of direct-current resistivity lines along canal roadside south and north lines. Adapted from original drawing provided by Nebraska Public Power District (Edward Dekleva Jr., written commun. 2012). 

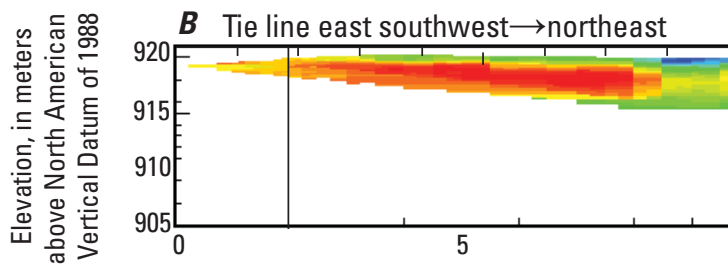

Distance (in meters)
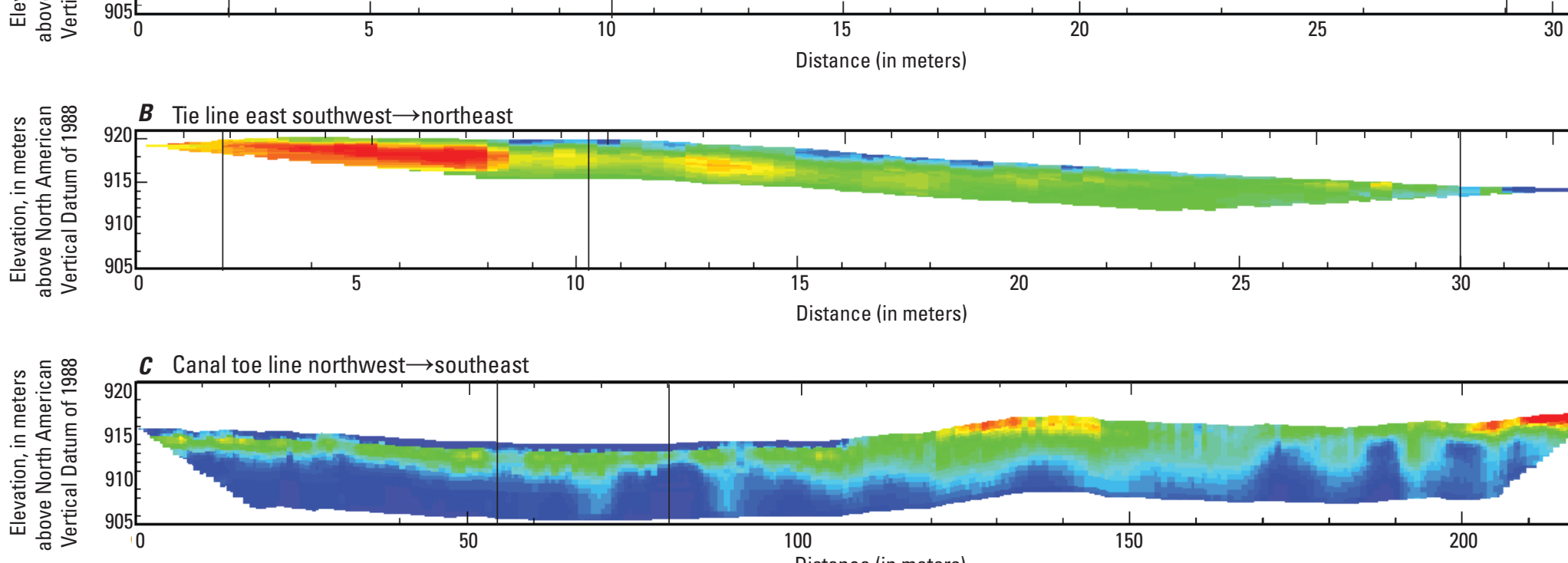

C Canal toe line northwest $\rightarrow$ southeast
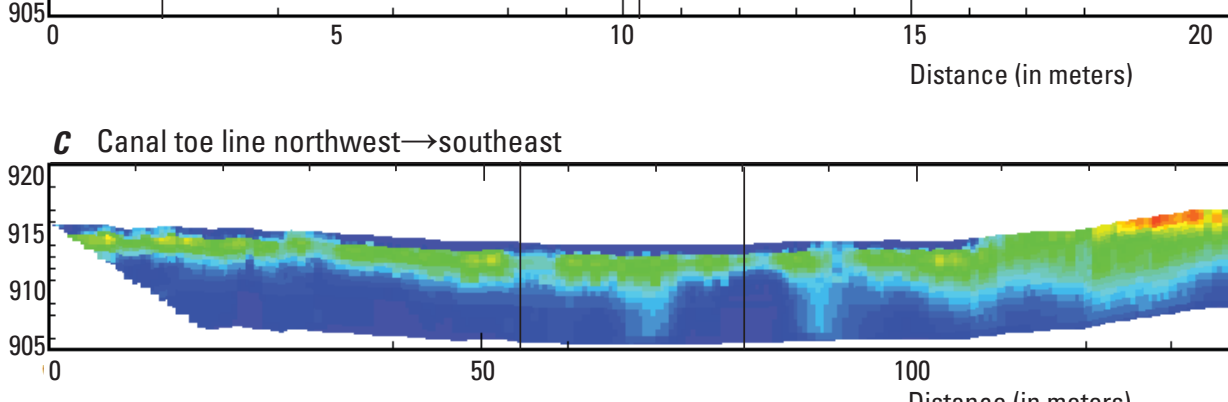

25

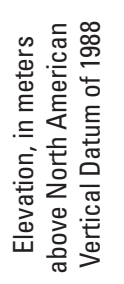

D Canal road north line northwest $\rightarrow$ southeast

Distance (in meters)

Piezometer PZ-4

_Piezometer PZ-5 Approximate groundwater level
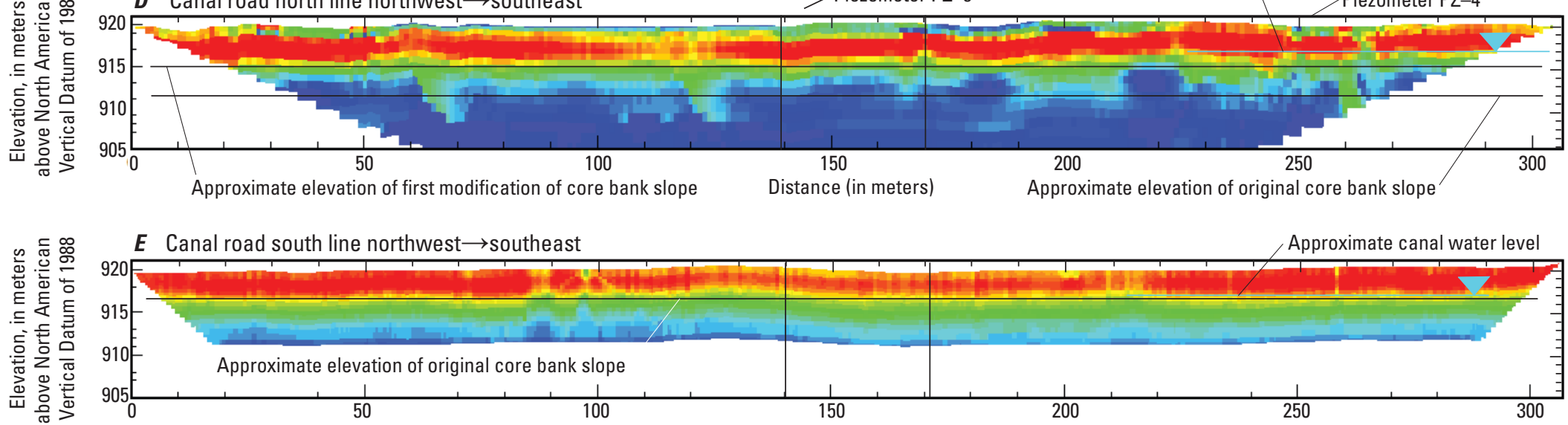

$\boldsymbol{E}$ Canal road south line northwest $\rightarrow$ southeast

Approximate canal water level

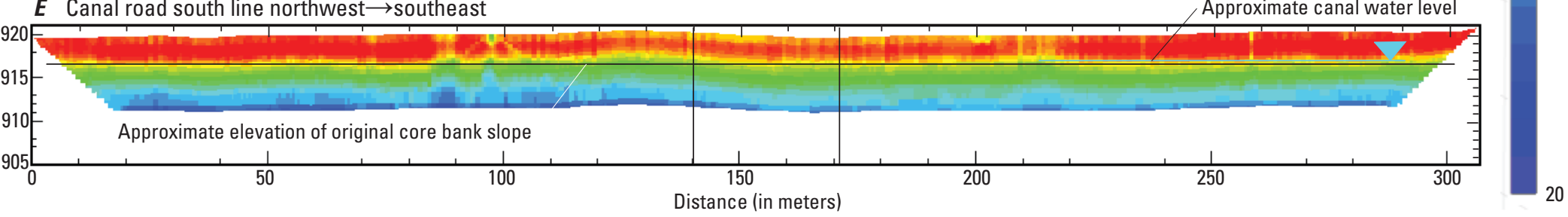

Figure 21. Inverse modeling results showing direct-current resistivity profiles at the seep near Outlet Canal mile post 15.55 along the canal access road and near piezometers PZ-4 and PZ-5. Vertical black lines indicate intersection with other survey lines. Map of direct-current resistivity lines are shown in figure 3B. Vertical exaggeration varies, but is about $5.2 x$ for $A$, tie line west and $B$, tie line east; about $0.74 x$ for $C$, canal toe line; and about $0.6 x$ for $D$, canal road north line and $E$, canal road south line. 


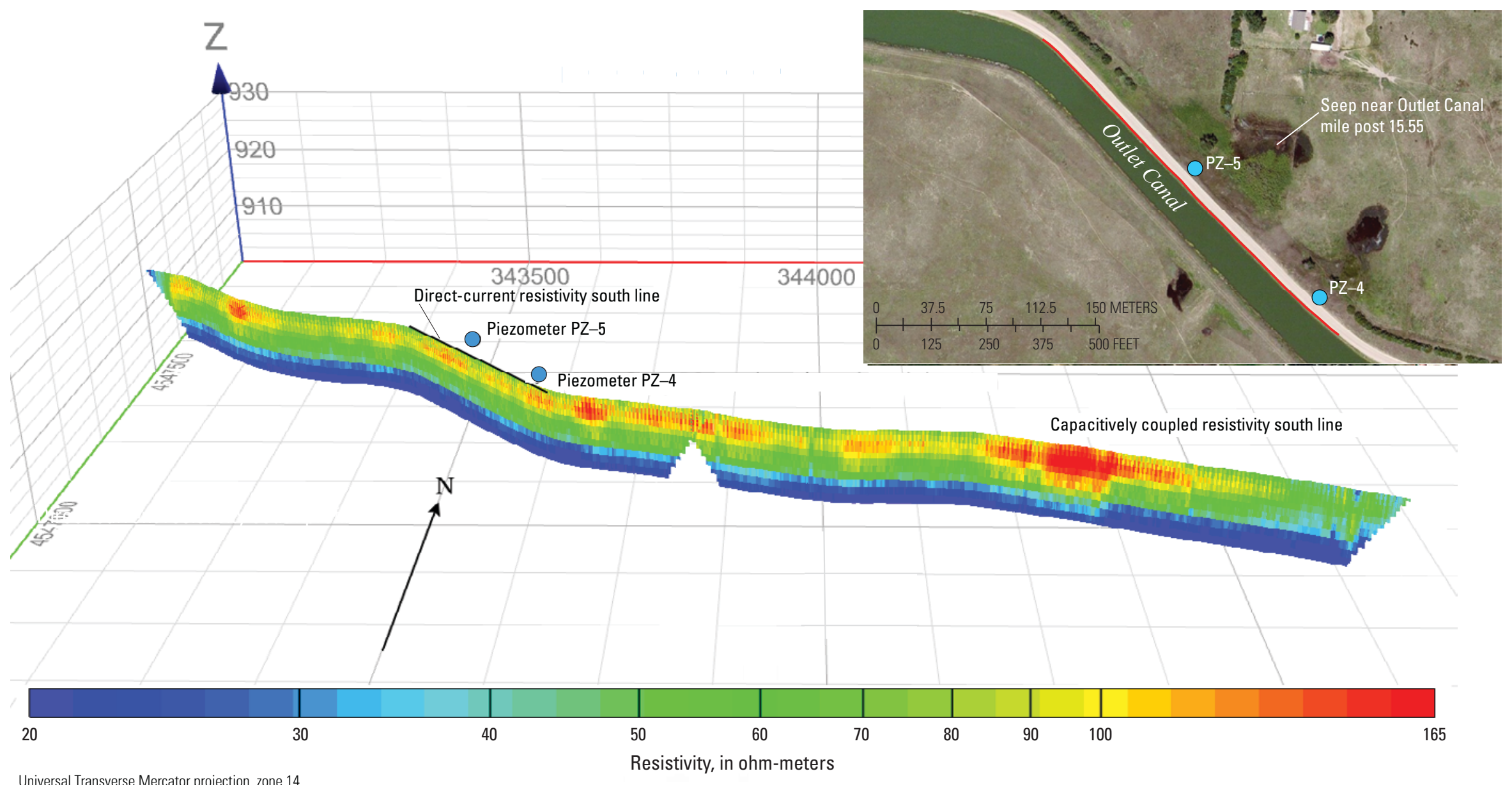

Northing and Easting coordinates given in meters,

Referenced to the North American Datum of 1983

Elevation given in meters above North American Vertical Datum of 1988

Figure 22. Inverse modeling results showing capacitively coupled resistivity profile for Outlet Canal access road south line near the seep near mile post 15.55 . $X$, $y$, and $z$ are easting, northing, and elevation in meters. (East one-half of surveyed line is shown. Vertical exaggeration is 10x.) 


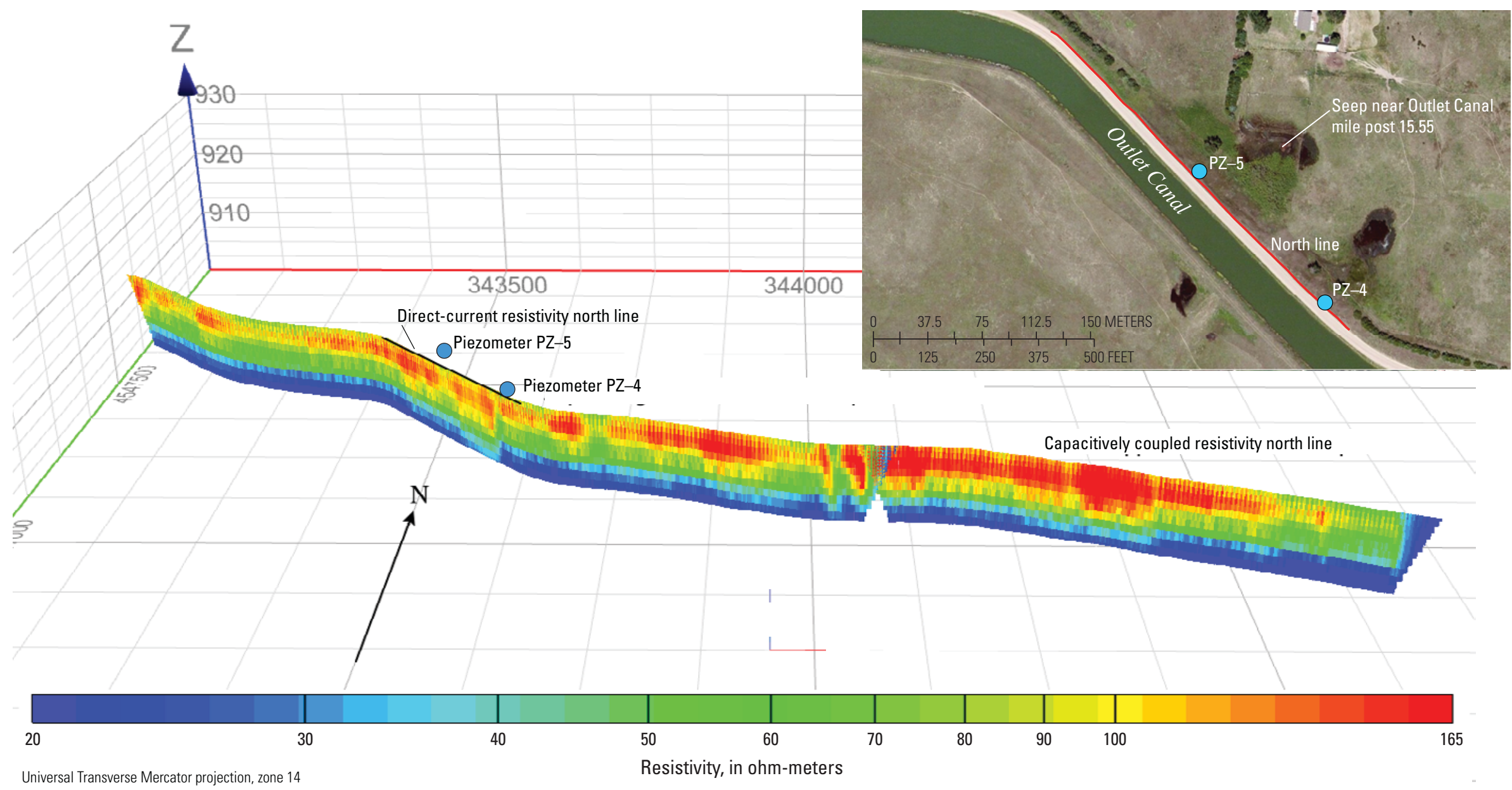

Northing and Easting coordinates given in meters,

Referenced to the North American Datum of 1983

Elevation given in meters above North American Vertical Datum of 1988

Figure 23. Inverse modeling results showing capacitively coupled resistivity profile for Outlet Canal access road north line near the seep near mile post $15.55 . X, y$, and $z$ are easting, northing, and elevation in meters. (East one-half of surveyed line is shown. Vertical exaggeration is 10x.) 


\section{Summary}

Understanding the spatial characteristics of leakage from canals is critical to effectively managing and utilizing water resources for irrigation and hydroelectric purposes. Canal leakage in some parts of Nebraska is the primary source of water for groundwater recharge and helps maintain the base flow of streams. Because surface-water supplies depend on the streamflow of the Platte River and the available water stored in upstream reservoirs, water managers seek to minimize conveyance losses, which can include canal leakage. Mapped geology beneath canals allows water managers to better understand the spatial variability and predict locations prone to canal leakage.

The USGS, in cooperation with the Central Platte Natural Resources District (CPNRD) and Nebraska Public Power District (NPPD), used capacitively coupled (CC) and directcurrent (DC) resistivity techniques for continuous resistivity profiling to map near-surface lithologies near and underlying the Cozad, Thirty-Mile, Orchard-Alfalfa, Kearney, and Outlet Canals. This report presents inverse modeling results from resistivity surveys acquired along 84 kilometers $(\mathrm{km})$ of canals, presented as two-dimensional, resistivity cross sections that extend to approximately 8 meters $(\mathrm{m})$ below land surface. The inverted resistivity data collected at selected reaches of all canals are compared with continuous sediment cores and paired direct-push electrical conductivity (EC) logs at locations selected on the basis of resistivity structure or anomalies in the surveyed CC-resistivity sections. Maps of the vertically averaged resistivity, which were used to interpret the relative leakage potential along the canals, also are presented.

Generally, the highest measured resistivities were recorded at the upstream reaches of the Cozad, Thirty-Mile, and Orchard-Alfalfa canals where flood-plain deposits of silt and clay mantle coarser alluvial deposits of sand and gravel. The finer grained deposits gradually thicken with increasing distance away from the Platte River. Consequently, for many surveyed reaches the thickness of fine-grained deposits exceeds the 8-m depth of investigation.

$\mathrm{CC}$ resistivity data were collected along Kearney Canal from the hydroelectric plant in the City of Kearney to Dove Hill Road approximately $8 \mathrm{~km}$ to the west. The purpose of the survey was to investigate the extent of a known focused seepage area. CC-resistivity profiles indicated a consistent resistivity pattern: a 4- to 5-m thick section of more resistive material ( 50 to $90 \mathrm{ohm}-\mathrm{m}$ ) overlies 3 or $4 \mathrm{~m}$ of lower-resistivity material (less than $15 \mathrm{ohm}-\mathrm{m}$ ). Given the generally consistent trend of the inverted CC-resistivity data, evidence for a focused seepage area is absent. The inverted data cannot indicate whether small, hydrologically significant features, such as macropores, may be present; such features are small and rare enough as to be unresolvable with this technique. The inconclusive results also indicates that the CC-resistivity method is more suitable for mapping general leakage trends where lithology is the primary control rather than small discrete features.

NPPD has identified locations along the Outlet Canal where seepage occurs through canal embankments downgradient of the canal. A detailed geophysical investigation along a 5-km reach of Outlet Canal southwest of North Platte, Nebraska, used CC- and DC-resistivity to examine the condition of the compacted-core bank structure and characterized other potential controls on areas of focused seepage. CC-resistivity data, collected along the 5-km study reach, were compared with continuous sediment cores and DC-resistivity data collected near a selected seep at Outlet Canal mile post 15.55 along 5 separate profiles. DC-resistivity results were compared to a schematic cross section of the Outlet Canal north embankment that plotted the original surfaces and modifications to the compacted-core bank structure.

Along the canal road south line, there is a transition from high resistivity at land surface to much lower resistivity near the estimated depth of the northern slope of the original compacted-core bank; however, the surveyed elevation of the water surface in the canal on April 20, 2012, also was at this elevation. Along the canal road north line, there is a transition from high resistivity near land surface to lower resistivity at depth. Although the transition is rapid near the estimated depth of the first-modified bank slope, it is also coincident with the groundwater level measured in piezometer PZ-4. Currently (2013), it is unknown if the indicated changes in resistivity at these elevations was the effect of saturation of the underlying sediments or caused by the compacted-core bank. If the core bank caused the detected contrast, then the lack of substantial variation in resistivity beneath the surface of the compactedcore bank suggests the compacted-core bank material was relatively homogeneous near this location.

The results of the surface resistivity surveys were inconclusive regarding identification of resistivity features in the embankment that are related to canal seepage at low-flow levels. Because NPPD personnel have noticed an apparent relation between seepage rates and canal flow rates, it may be advantageous to resurvey the same areas again when water level in the canal is higher. During times when the watersurface elevation of the canal is higher, focused seepage may occur through these areas of higher resistivity. With saturation, the resistivity therein is expected to decrease, potentially making a detectable contrast with drier areas. 


\section{References Cited}

Advanced Geosciences, Inc., 2008, Instruction manual for EarthImager 2D, version 2.3.0-Resistivity and IP inversion software: Austin, Tex., Advanced Geosciences, Inc., 139 p.

ASTM International, 2011, Standard practice for classification of soils for engineering purposes (Unified Soil Classification System): Active Standard ASTM D2487-11, 12 p.

Asch, T.H., Deszcz-Pan, Maria, Burton, B.L., and Ball, L.B., 2008, Geophysical characterization of American River levees, Sacramento, California, using electromagnetics, capacitively coupled resistivity, and DC resistivity: U.S. Geological Survey Open-File Report 2008-1109, 12 p.

Ball, L.B., Kress, W.H., Steele, G.V., Cannia, J.C., and Andersen, M.A., 2006, Determination of canal leakage potential using continuous resistivity profiling techniques, Interstate and Tri-State Canals, western Nebraska and eastern Wyoming, 2004: U.S. Geological Survey Scientific Investigations Report 2006-5032, 53 p., accessed February 2013, at http://pubs.usgs.gov/sir/2006/5032/.

Burton, B.L., and Cannia, J.C., 2011, Capacitively coupled resistivity survey of the levee surrounding the Omaha Public Power District Nebraska City Power Plant, June 2011: U.S. Geological Survey Open-File Report 2011-1211, 10 p.

Burton, B.L., Johnson, M.R., Vrabel, Joseph, Imig, B.H., Payne, J.D., and Tompkins, R.E., 2009, Capacitively coupled resistivity survey of selected irrigation canals within the North Platte River valley, western Nebraska, and eastern Wyoming, 2004 and 2007-2009: U.S. Geological Survey Scientific Investigations Report 2009-5194, 70 p., accessed February 2013, at http://pubs.usgs.gov/sir/2009/5194/.

Butler, D.K., ed., 2005, Near-surface geophysics; Investigations in geophysics, No. 13: Tulsa, Okla., Society of Exploration Geophysicists, $732 \mathrm{p}$.

Cannia, J.C., Woodward, D.D., and Cast, L.D., 2006, Cooperative Hydrology Study [COHYST] hydrostratigraphic units and aquifer characterization report: Lincoln, Nebr., Nebraska Department of Natural Resources, 96 p.

Carney, C.P., 2008, Groundwater flow model of the central model unit of the Nebraska Cooperative Hydrology Study (COHYST) area: Lincoln, Nebr., Nebraska Department of Natural Resources, 87 p., accessed February 2013, at http:// cohyst.dnr.ne.gov/adobe/dc012CMU_GFMR_081224.pdf.

Central Platte Natural Resources District, 2012, Integrated management plan: Grand Island, Nebr., Central Platte Natural Resources District, 39 p., accessed May 2013, at www. cpnrd.org/2012\%20Final\%20IMP.pdf.
Cooperative Hydrology Study, 2013, Platte River Cooperative Hydrology Study: Lincoln, Nebr., accessed August 28, 2013, at http://cohyst.dnr.ne.gov/.

Condon, S.M., 2005, Geologic studies of the Platte River, south-central Nebraska and adjacent areas - Geologic maps, subsurface study, and geologic history: U.S. Geological Survey Professional Paper 1706, 63 p.

Condra, G.E., and Reed, E.C., 1943, The geological section of Nebraska: Nebraska Geological Survey (University of Nebraska-Lincoln) Bulletin, v. 14, p. 82.

Darton, N.H., 1898, Underground waters of a portion of southeastern Nebraska: U.S. Geological Survey Water Supply and Irrigation Paper 12, 56 p.

Darton, N.H., 1905, Preliminary report on the geology and underground water resources of the central Great Plains: U.S. Geological Survey Professional Paper 32, 433 p.

Esri, 2013a, World imagery: ArcGIS World Imagery, accessed February 25, 2013, at http://goto.arcgisonline.com/maps/ World_Imagery.

Esri, 2013b, World Shaded Relief: ArcGIS World Imagery, accessed February 25, 2013, at http://goto.arcgisonline.com/ maps/World_Shaded_Relief.

Fenneman, N.M., and Johnson, D.W., 1946, Physiographic divisions of the conterminous United States: U.S. Geological Survey Special Map Series, scale 1:7,000,000.

Geometrics, 2001, OhmMapper TR1 operation manual, rev. F: San Jose, Calif., Geometrics, Inc., 147 p., accessed April 2013, at ftp://geom.geometrics.com/pub/GeoElectric/ Manuals/OhmMapper-Manual-TRN-2004.pdf.

Geometrics, 2013, Magmap 20004.0 user guide, rev. H: San Jose, Calif., Geometrics, Inc., 235 p., accessed February 2013, at ftp://geom.geometrics.com/pub/mag/Manuals/ MagMap2000Manual.pdf.

Gillip, J.A., and Payne, J.D., 2011, Geophysical characterization of the Lollie Levee near Conway, Arkansas, using capacitively coupled resistivity survey, coring, and direct-push logging: U.S. Geological Survey Data Series Report 640, $27 \mathrm{p}$.

Goeke, J.W., Peckenpaugh, J.M., Cady, R.E., and Dugan, J.T., 1992, Hydrogeology of parts of the Twin Platte and Middle Republican Natural Resources Districts, southwestern Nebraska: Lincoln, Nebr., University of Nebraska, Conservation and Survey Division Water Supply Paper no. 70, $89 \mathrm{p}$. 
Gutentag, E.D., Heimes, F.J., Krothe, N.C., Luckey, R.R., and Weeks, J.B., 1984, Geohydrology of the High Plains aquifer in parts of Colorado, Nebraska, New Mexico, Oklahoma, South Dakota, Texas, and Wyoming: U.S. Geological Survey Professional Paper 1400-B, 63 p.

Hobza, C.M., and Andersen, M.J., 2010, Quantifying canal leakage rates using a mass-balance approach and heatbased hydraulic conductivity estimates in selected irrigation canals, western Nebraska, 2007 through 2009: U.S. Geological Survey Scientific Investigations Report 2010-5226, 45 p. (Also available at http://pubs.usgs.gov/ sir/2010/5226/.)

Irons, T.P., Hobza, C.M., Steele, G.V., Abraham, J.D., Cannia, J.C., and Woodward, D.D., 2012, Quantification of aquifer properties with surface nuclear magnetic resonance in the Platte River valley, central Nebraska, using a novel inversion method: U.S. Geological Survey Scientific Investigations Report 2012-5189, 50 p. (Also available at http:// pubs.usgs.gov/sir/2012/5189/.)

Kejr, Inc., 2009, Direct Image_-Geoprobe systems: Salina, Kans., Kejr, Inc., accessed February 2013, at http:// geoprobe.com/node/1531/content/view/20/30/.

Law Information Institute, 2013, Prior appropriation doctrine: Cornell University Law School, Ithaca, N.Y., accessed August 26, 2013, at http://www.law.cornell.edu/wex/prior_ appropriation_doctrine.

Lindburg, Matt, 2005, Existing hydrologic conditions and irrigation practices in the central Platte River valley, Nebraska-Evaluation and development of a conjunctive water resource management for the Gothenburg to Kearney reach of the central Platte valley, Nebraska: Columbus, Nebr., Nebraska Public Power District, 24 p., accessed February 15, 2013, at http://dnr.ne.gov/PlatteRiver/docs/Existin gConditionsReportDoc_0607.pdf.

Loke, M.H., 2009, RES2DINV, ver. 3.58, manual-Rapid 2D resistivity and IP inversion using the least-squares method: Penang, Malaysia, Geotomo Software, 151 p., accessed May 2009, at http://www.geotomosoft.com/downloads.php.

Lucius, J.E., Abraham, J.D., and Burton, B.L., 2008, Resistivity profiling for mapping gravel layers that may control contaminant migration at the Amargosa Desert Research Site, Nevada: U.S. Geological Survey Scientific Investigations Report 2008-5091, 30 p. (Also available at http://pubs.usgs. gov/sir/2008/5091/.)

Lucius, J.E., Langer, W.H., and Ellefsen, K.J., 2007, An introduction to using surface geophysics to characterize sand and gravel deposits: U.S. Geological Survey Circular 1310, 33 p. (Also available at http://pubs.usgs.gov/ circ/2007/1310/.)
Luckey, R.R., and Cannia, J.C., 2006, Ground water flow model of the western model unit of the Nebraska Cooperative Hydrology Study (COHYST) area: Lincoln, Nebr., Nebraska Department of Natural Resources, 63 p., accessed May 2013, at http://cohyst.dnr.ne.gov/adobe/dc012WMU_ GFMR_060519.pdf.

Lugn, A.L., and Wenzel, L.K., 1938, Geology and groundwater resources of south-central Nebraska, with special reference to the Platte River valley between Chapman and Gothenburg: U.S. Geological Survey Water-Supply Paper 779, 242 p.

Munsell Color, 1992, Munsell soil color charts: Newburg, N.Y., Macbeth Division of Kollmorgen Instruments Corporation, $10 \mathrm{p}$.

National Oceanic and Atmospheric Administration, 2010, Climatological data annual summary, 2009: Asheville, N.C., National Climatic Data Center, accessed February 2013, at http://www.ncdc.noaa.gov/cdo-web/datasets/ANNUAL/ stations/COOP:253365/detail.

Nebraska Public Power District, 2013, Irrigation: accessed August 2013, at http://www.nppd.com/about-us/powerplants-facilities/irrigation/.

OmniSTAR, 2005, High precision subscription service: Houston, Tex., OmniSTAR, Inc., accessed April 2013, at http:// www.omnistar.com/Support/FAQs.aspx.

Peckenpaugh, J.M., and Dugan, J.T., 1983: Hydrology of parts of the Central Platte and Lower Loup Natural Resources Districts, Nebraska: U.S. Geological Survey WaterResources Investigations Report 83-4219, 125 p.

Peterson, S.P., 2007, Groundwater flow model of the eastern model unit of the Nebraska Cooperative Hydrology Study (COHYST) area: Lincoln, Nebr., Nebraska Department of Natural Resources, 80 p., accessed February 2013, at http:// cohyst.dnr.ne.gov/adobe/dc012EMU_GFMR_090507.pdf.

Pitney Bowes Software, 2014, Encom Profile Analyst: North Sydney, Austrailia, accessed January 17, 2014, at http:// www.encom.com.au/template2.asp? pageid $=16$.

Reynolds, J.M., 1997, An introduction to applied and environmental geophysics: Chichester, England, Wiley, 796 p.

Sharma, P.V., 1997, Environmental and engineering geophysics: Cambridge, United Kingdom, Cambridge University Press, $475 \mathrm{p}$.

Tetra Tech, 2012, Geotechnical investigation-Canal seepage mitigation and embankment stabilization for the North Supply and Outlet Canals, Sutherland, Nebraska: Longmont, Colo., Tetra Tech, Job No. 133-04393-11004, 146 p. 
Timofeev, V.M., Rogozinski, A.W., Hunter, J.A., and Douma, M., 1994, A new ground resistivity method for engineering and environmental geophysics, in Symposium on the Application of Geophysics to Engineering and Environmental Problems, Boston, Mass., 1994, Proceedings: Denver, Colo., Environmental Engineering Geophysical Society, p. 701-715.

U.S. Department of Agriculture, 2012, National Agriculture Imagery Program Orthophotography: accessed March 12, 2013, at http://gis.apfo.usda.gov/arcgis/services.

Waite, H.A., and others, 1949, Progress report on the geology and ground-water hydrology of the lower Platte River valley, Nebraska, with a section on Chemical quality of the ground water, by H.A. Swensen: U.S. Geological Survey Circular 20, $211 \mathrm{p}$.

Publishing support provided by: Rolla Publishing Service Center

For more information concerning this publication, contact: Director, USGS Nebraska Water Science Center 5231 South 19th Street

Lincoln, NE 68512

(402) 328-4100

Or visit the Nebraska Water Science Center Web site at: http://ne.water.usgs.gov 

.ัญ

焉

옥

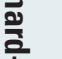

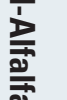

त

(2) 